\title{
Ninety million years of orogenesis, 250 million years of quiescence and further orogenesis with no change in PT: Significance for the role of deformation in porphyroblast growth
}

\author{
A A SHAH ${ }^{1,2, *}$ and $\mathrm{T} \mathrm{H} \mathrm{BELL}^{1}$ \\ ${ }^{1}$ School of Earth and Environmental Sciences, James Cook University, Townsville, Qld 4811, Australia. \\ ${ }^{2}$ Earth Observatory of Singapore, Nanyang Technological University, Singapore. \\ ${ }^{*}$ Corresponding author.e-mail: afroz@ntu.edu.sg
}

\begin{abstract}
In situ dating of monazite grains preserved as inclusions within foliations defining FIAs (foliation inflection/intersection axes preserved within porphyroblasts) contained within garnet, staurolite, andalusite and cordierite porphyroblasts provides a chronology of ages that matches the FIA succession for the Big Thompson region of the northern Colorado Rocky Mountains. FIA sets 1, 2 and 3 trending NE-SW, E-W and SE-NW were formed at 1760.5 \pm 9.7, $1719.7 \pm 6.4$ and $1674 \pm 11$ Ma, respectively. For three samples where garnet first grew during just one of each of these FIAs, the intersection of Ca, $\mathrm{Mg}$, and $\mathrm{Fe}$ isopleths in their cores indicate that these rocks never got above 4 kbars throughout the Colorado Orogeny. Furthermore, they remained around approximately the same depth for $\sim 250$ million years to the onset of the younger Berthoud Orogeny at $1415 \pm 16 \mathrm{Ma}$ when the pressure decreased slightly as porphyroblasts formed with inclusion trails preserving FIA set 4 trending NNE-SSW. No porphyroblast growth occurred during the intervening $~ 250$ million years of quiescence, even though the PT did not change over this period. This confirms microstructural evidence gathered over the past 25 years that crenulation deformation at the scale of a porphyroblast is required for reactions to re-initiate and enable further growth.
\end{abstract}

\section{Introduction}

In multiply deformed and metamorphosed rocks, foliations in the matrix, especially schistosity parallel to compositional layering, have generally undergone long and complex histories (e.g., Ham and Bell 2004). Different relics of this history can be left in strain shadows or portions where later deformation partitioning was less pervasive and if not decoded carefully will lead to erroneous or ambiguous results (e.g., Spiess and Bell 1996). Each new deformation tends to erase developing or earlier-formed structures through decrenulation of developing crenulation cleavage and rotation of relics of earlier-formed foliations into parallelism with the compositional layering (e.g., Bell et al. 2003). Deformation partitioning strongly affects such kinds of processes from regional (Cihan and Parsons 2005) to porphyroblastic scales (Bell and Bruce 2007) and makes it difficult to correlate them from one region to another. It is primarily because a mixture of ages will always be present within matrix of such rocks and gets even worst if deformation partitioning was intense. The inclusion trails preserved within porphyroblasts are remnants of earlier matrix events. These are

Keywords. FIAs; porphyroblast; monazite; garnet; staurolite. 
generally isolated from the matrix phases and act as robust candidates for studying deformation and metamorphic processes. Such quantitative research has greatly increased our understanding of complex inclusion trail relationships, which otherwise could not be interpreted or were misleading (e.g., Ham and Bell 2004).

Accurate measurement of the foliation inflection/ intersection axes preserved within different porphyroblastic phases (FIAs) has made it possible to decode lengthy and complex histories of deformation and metamorphism in orogens around the world (e.g., Bell et al. 2004). More than 10 years of research and data have already been published using this technique from tectonically complex regions around the world (e.g., Bell et al. 1998, 2003, 2005; Bell and Chen 2002; Cihan 2004; Kim and Bell 2005; Sayab 2005, 2006; Bell and Bruce 2007; Sanislav 2010; Sanislav and Shah 2010; Ali 2010; Sanislav and Bell 2011).

The integration of detailed microstructural studies and FIA data with garnet isopleth thermobarometry/MnNCKFMASH pseudosection construction can provide complete pressure-temperaturetime deformational trajectories of an area (e.g., Kim and Bell 2005; Cihan et al. 2006; Sayab 2006; Ali 2010). Such an approach significantly improves our understanding of large-scale orogenic processes. But the absolute timing of these events remains a fundamental tool for decoding and interpreting the tectonic evolution of the region. Geometrically and texturally controlled dating methods are critical for constraining the ages of deformed and metamorphosed sediments and their textures and foliations (e.g., Williams and Jercinovic 2002). In pelites and psammites, monazite is commonly present at amphibolite facies (Dahl et al. 2005) and it has been dated in migmatites and granulites (e.g., Kelly et al. 2006). It is considered as a typical mineral of choice for in situ geochronology in such rocks (Dahl et al. 2005; Williams et al. 2007).

Absolute dating of monazite grains applying high precission electron microprobe U-Th-Pb techniques (EPMA) was used to correlate different metamorphic and deformational events (e.g., Montel et al. 1996; Dahl et al. 2005) because the bulk of the monazite grains analysed were smaller in size. Dating of monazite inclusions within different FIA sets (Bell and Welch 2002; Ali 2010; Sanislav 2010; Sanislav and Shah 2010) provides a robust tool for understanding and unravelling lengthy and complex orogenic histories. Integration of FIAs with this approach provides a strong basis for studying the complex pressure-temperature-time-deformation ( $\mathrm{PT}-\mathrm{t}-\mathrm{D})$ paths that rocks appear to have followed. This paper reports the results obtained from adapting

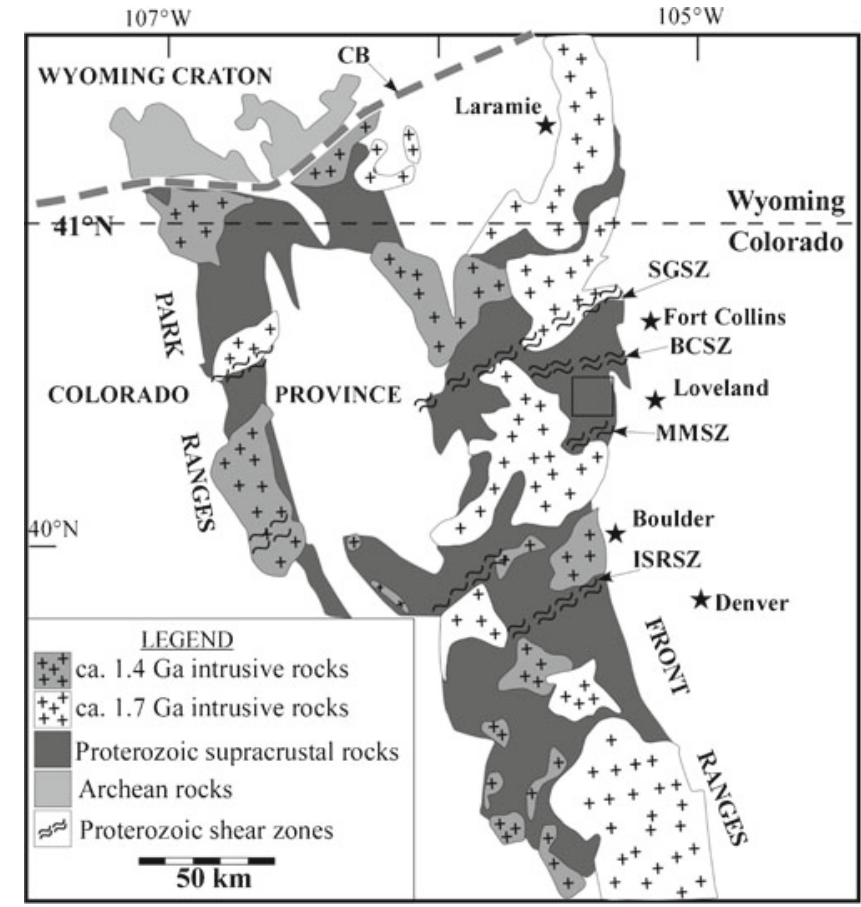

Figure 1. Regional map of the Colorado Frontal Range showing the Precambrian rocks and the location of the study area (box shows area of figure 2). BCSZ: Buckhorn Creek shear zone, CB: Cheyenne belt, ISRSZ: Idaho SpringsRalston shear zone, MMSZ: Moose Mountain shear zone, SGSZ: Skin Gulch shear zone (modified after Cavosie and Selverstone 2003).

this approach to the rocks collected in and around the Big Thompson region of Colorado (figures 1 and 2).

\section{Regional geology and tectonics}

The rocks exposed in the Big Thomson Canyon region, Colorado, USA, are mainly metasediments and granitoids (figure 2). Condie and Martel (1983) suggested that the metasediments represent mature sediments deposited in a forearc setting. Reed et al. (1987) argued that they were possibly deposited in a back-arc setting between two $\sim 1.8$ and 1.7 Ma magmatic arc systems. Recent detrital zircon ages suggest a maximum age of $1758+26$ Ma for deposition of the Big Thompson sequence (Selverstone et al. 2000). These sediments were repeatedly deformed, metamorphosed and intruded by various plutons (e.g., Braddock and Cole 1979; Selverstone et al. 1997; Sims et al. 2003) during the Colorado ( 1700 Ma) and Berthoud ( 1400 Ma) orogenies (Tweto 1987; Nyman et al. 1994; Karlstrom et al. 1997). The rocks show an increase in metamorphic grade towards the west and north and three stages of folding and cleavage development (Cavosie and Selverstone 2003). 
Millions of years of orogenesis and quiescence and further orogenesis with no change in PT 1367

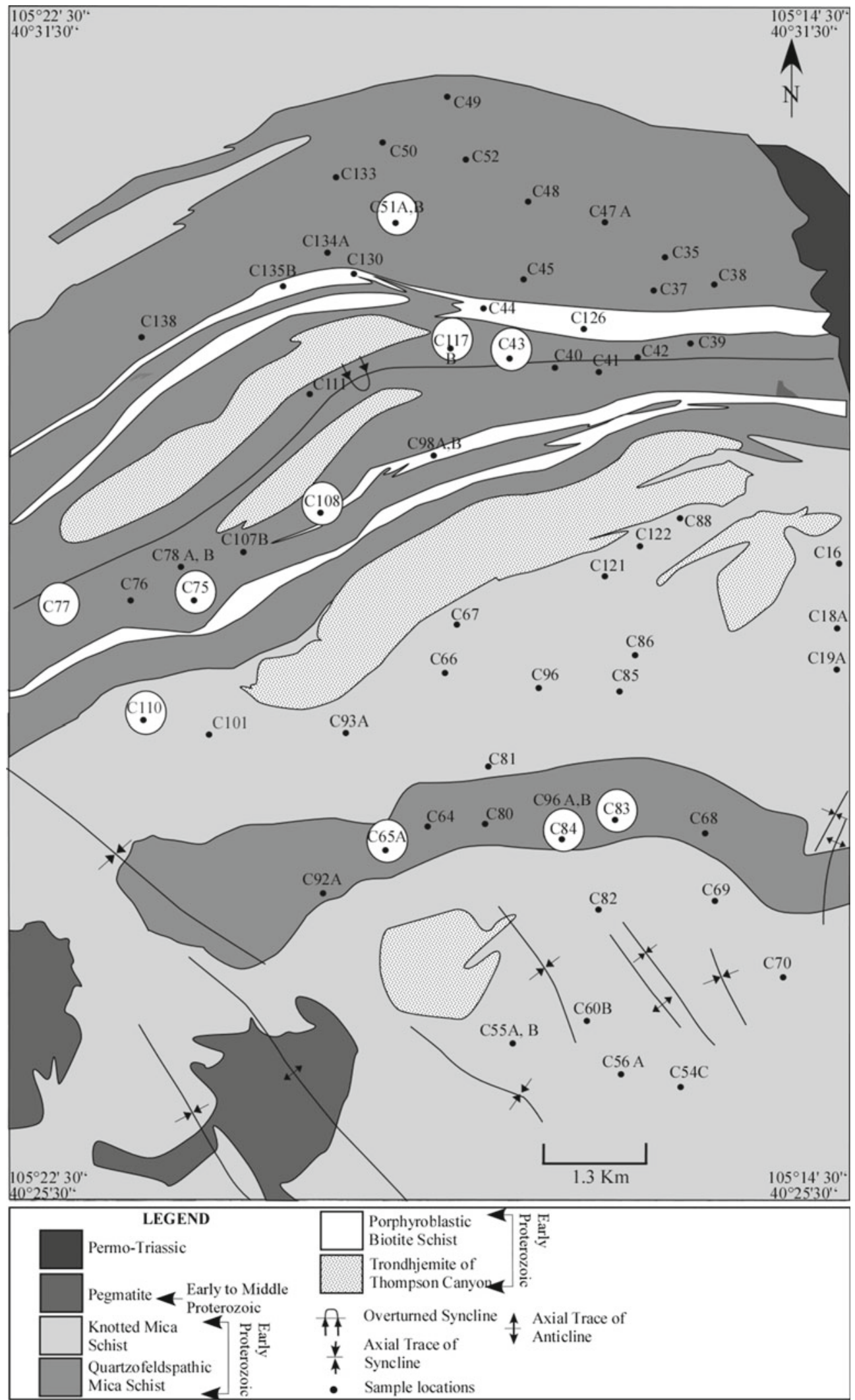

Figure 2. Detailed geological map of the study area and the sample locations. White circles show the location of samples used for monazite dating (geological map modified after Cavosie and Selverstone 2003). 
The first deformation/metamorphism occurred before $1750 \mathrm{Ma}$ and resulted in large-scale isoclinal folds (F1) and a regional axial cleavage S1. The second and third stages of folding (F2 and F3) occurred around $1750 \mathrm{Ma}$ ago, when these rocks were intruded by the Boulder Creek granodiorite and related rocks. Only one period of metamorphism has been associated with these events (M1) during which garnet and staurolite grew. The second metamorphic event (M2), which was stronger than the first, resulted in the formation of up to sillimanite grade mineral assemblages (Sims et al. 2003), though metamorphic conditions were very heterogeneous throughout these episodes. A number of areas recorded an entire transition in metamorphic grade from the chlorite zone to the onset of migmatization during the Colorado orogeny (Braddock and Cole 1979; Selverstone et al. 1997).

\section{Methods}

\subsection{FIA measurements}

Hayward (1990) and Bell et al. (1995, 1998) described a technique for analysing the geometries of inclusion trails within porphyroblasts. It involves measurement of the FIA, which is achieved by cutting a minimum of eight vertically oriented thin sections around the compass from each rock sample to locate the switch in inclusion trail asymmetry (clockwise or anticlockwise) within the porphyroblasts (figure $3 \mathrm{a}$ and $\mathrm{b}$ ). Where the FIA trends vary from the core to the rim of the porphyroblasts, a relative timing and thus an FIA succession can be established (Bell et al. 1998). The accumulated error associated with determining the trend of the FIA in each rock is random, and is estimated to be \pm 8 in both situations when one uses a COCLAR compass (see Bell et al. 1998).

\section{Results}

\subsection{FIA data}

A total of 67 oriented samples were examined for the present research. 800 oriented thin sections were prepared and a total of 138 FIA and pseudo-FIA trends were determined (table 1 , figure 2). These measurements were achieved by cutting a minimum of eight vertically oriented thin sections around the compass from each rock sample (figure 3) and then locating the switch in inclusion trail asymmetry (clockwise or anticlockwise) within the porphyroblasts (e.g., Bell et al. 1998).

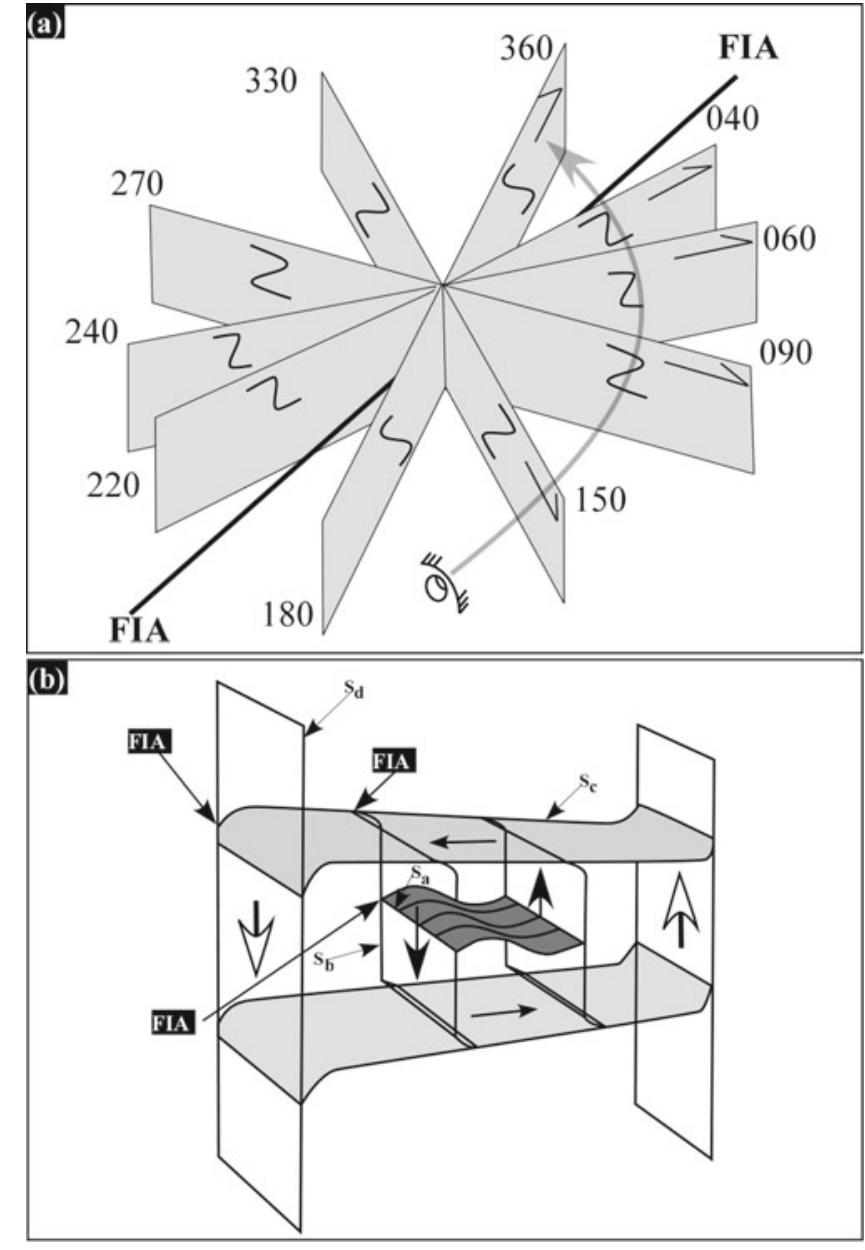

Figure 3. (a) Sketch illustrating the method developed by Bell et al. $(1995,1998)$ by which the trend of an FIA is measured. This technique uses the change in asymmetries of inclusion trails in a porphyroblast, when viewed in a consistent direction for successive striking vertical thin sections, to locate the FIA. The inclusion trail asymmetry changes between $0^{\circ}$ and $40^{\circ}$. Thin section orientation is marked as single barbed arrow. The eyeball and grey arrow indicates the direction in which the sections are viewed. (b) The 3-D sketch illustrates a succession of foliations, as they would be preserved within a vertical slice through a porphyroblast, which define a single FIA trend.

Garnet, staurolite, andalusite and cordierite porphyroblasts preserve earlier foliations as inclusion trails. These foliations are most commonly straight with curvature at their extremities (e.g., figure 4a). Porphyroblast inclusion trails are commonly truncated (e.g., figure 4a) by the matrix foliations but some are not (e.g., figure 4b). A relative timing and thus an FIA succession can be established from samples preserving an FIA trend that varies from core to the rim of the porphyroblast (e.g., Bell et al. 1998). All FIA measurements are plotted on rose diagram and are shown in figure 5(a). A total of 64 and 53 FIAs were measured in garnet and staurolite porphyroblasts respectively (figure $5 \mathrm{~b}$ and $\mathrm{c}$ ). 
Table 1. Samples collected in and around Big Thompson Canyon region of northern Front Range, Colorado (shown in figure 2), the geological formations from which they were taken, their latitude and longitude values and the FIA trends measured in them.

\begin{tabular}{|c|c|c|c|c|c|c|c|c|c|c|c|c|}
\hline Sample & Easting & Northing & FM & $\begin{array}{c}\text { Garnet } \\
\text { single } \\
\text { FIA }\end{array}$ & pFIA & Core & Rim & $\begin{array}{c}\text { Staurolite } \\
\text { single } \\
\text { FIA }\end{array}$ & pFIA & $\begin{array}{c}\text { Cordierite } \\
\text { single } \\
\text { FIA }\end{array}$ & pFIA & $\begin{array}{c}\text { Andalusite } \\
\text { single } \\
\text { FIA } \\
\end{array}$ \\
\hline C16 & $\mathrm{N}$ & & & 15 & & & & & & & & \\
\hline C18A & $\mathrm{N}$ & & & 15 & & & & & & & & \\
\hline C18B & $\mathrm{N}$ & & & 15 & 130 & & & & & & & \\
\hline C19A & $\mathrm{N}$ & & & 15 & 135 & & & & & & & \\
\hline C35 & 477206 & 4484713 & XKS & 55 & & & & 25 & & & & \\
\hline C37 & 477144 & 4484332 & XBS & 140 & & & & 30 & & & & \\
\hline $\mathrm{C} 38$ & 477712 & 4484329 & XKS & & & & & 15 & & & & \\
\hline C39 & 477339 & 4483694 & XKS & 90 & & & & 20 & & & & \\
\hline $\mathrm{C} 40$ & 475828 & 4483433 & XKS & 85 & 50 & & & 135 & & & & \\
\hline C41 & 476404 & 4483291 & XKS & & & & & 30 & & & & \\
\hline $\mathrm{C} 42$ & 476752 & 4483561 & XKS & 55 & & & & 25 & & & & \\
\hline $\mathrm{C} 43$ & 475001 & 4483553 & XKS & 50 & & & & 80 & & & & \\
\hline C44 & 474752 & 4484140 & XKS & 80 & & & & 15 & 130 & & & \\
\hline $\mathrm{C} 45$ & 475338 & 4484548 & XKS & 85 & & & & 140 & & & & \\
\hline $\mathrm{C} 47 \mathrm{~A}$ & 476418 & 4485315 & XKS & 140 & & & & 25 & & & & \\
\hline $\mathrm{C} 48$ & 475216 & 4485600 & XKS & & & & & 135 & & & & \\
\hline C49 & 474307 & 4486810 & XKS & & & & & 90 & & 120 & & \\
\hline C50 & 473290 & 4486411 & XKS & & & & & 135 & & 25 & & 25 \\
\hline C51A & 473670 & 4485437 & XKS & 130 & & & & & & & & \\
\hline C51B & 473670 & 4485437 & XKS & 55 & & & & & & 125 & & \\
\hline C52 & 474484 & 4485910 & XQS & & & 50 & 85 & & & 25 & & \\
\hline C54C & 476858 & 4474303 & XQS & 25 & & & & 25 & & & & \\
\hline C55A & 474470 & 4475194 & XQS & 55 & & & & & & & & \\
\hline C55B & 474470 & 4475194 & XQS & 40 & & & & 15 & & & & \\
\hline C56A & 475827 & 4474568 & XQS & 45 & & & & 125 & & & & \\
\hline C60B & 475036 & 4475308 & XQS & & & & & 85 & & & & \\
\hline C64 & 473360 & 4477763 & XKS & 85 & 40 & & & 125 & & & & \\
\hline C65A & 472961 & 4477978 & XQS & 55 & & & & 130 & 80 & & & \\
\hline C66 & 473717 & 4479430 & XQS & 50 & & & & 120 & 40 & & & \\
\hline C67 & 473793 & 4480256 & XQS & & & 85 & 130 & & & & & \\
\hline C68A & 476612 & 4477904 & XKS & & & & & 120 & & & & \\
\hline C68B & 476612 & 4477904 & XKS & 90 & 50 & & & & & & & \\
\hline C69 & 477142 & 4476720 & XQS & & & 130 & 25 & & & & & \\
\hline $\mathrm{C} 70$ & 477433 & 4475714 & XQS & 85 & & & & & & & & \\
\hline C75 & 470687 & 4480815 & XBS & & & & & 85 & 60 & & & \\
\hline C76 & 469767 & 4480350 & XQS & & & 85 & 135 & & & 25 & & 125 \\
\hline $\mathrm{C} 77$ & 469104 & 4480353 & XQS & & & & & & & & 120 & \\
\hline $\mathrm{C} 78 \mathrm{~A}$ & 470822 & 4479966 & XQS & 45 & & & & 25 & & 115 & & \\
\hline C78B & 470822 & 4479966 & XQS & 85 & 50 & & & 130 & & 130 & & \\
\hline C80 & 474017 & 4478095 & XKS & & & & & 85 & & & & \\
\hline C 81 & 474505 & 4478748 & XQS & 145 & & & & 15 & & & & \\
\hline C 82 & 475584 & 4476971 & XQS & 125 & & & & 30 & & & & \\
\hline C83 & 475634 & 4477975 & XKS & 80 & & & & 135 & & & & \\
\hline $\mathrm{C} 84$ & 474792 & 4477824 & XKS & 85 & & & & 130 & & & & \\
\hline C 85 & 475463 & 4479506 & XQS & 90 & & & & 30 & & & & \\
\hline C 86 & 476096 & 4479964 & XQS & 125 & 50 & & & & & & & \\
\hline C88 & 476418 & 4481613 & XQS & 55 & & & & 25 & & & & \\
\hline $\mathrm{C} 92 \mathrm{~A}$ & 472011 & 4477468 & XKS & 130 & & & & & & & & \\
\hline C93A & 472642 & 4479207 & XQS & 55 & & & & 30 & & & & \\
\hline C96A & 475043 & 4479775 & XQS & 85 & & & & 130 & & & & \\
\hline C96B & 475043 & 4479775 & XQS & & & 55 & 135 & & & & & \\
\hline
\end{tabular}


Table 1. (Continued)

\begin{tabular}{|c|c|c|c|c|c|c|c|c|c|c|c|c|}
\hline Sample & Easting & Northing & $\mathrm{FM}$ & $\begin{array}{c}\text { Garnet } \\
\text { single } \\
\text { FIA }\end{array}$ & pFIA & Core & Rim & $\begin{array}{c}\text { Staurolite } \\
\text { single } \\
\text { FIA }\end{array}$ & pFIA & $\begin{array}{c}\text { Cordierite } \\
\text { single } \\
\text { FIA }\end{array}$ & pFIA & $\begin{array}{c}\text { Andalusite } \\
\text { single } \\
\text { FIA }\end{array}$ \\
\hline C98A & 473791 & 4482058 & XBS & & & & & 55 & & 25 & & \\
\hline C98A & 473791 & 4482058 & XBS & 55 & & & & 90 & & 30 & & \\
\hline C101 & 470677 & 4478975 & XKS & 15 & 85 & & & & & 30 & & \\
\hline C107B & 471172 & 4481971 & XKS & 50 & & & & 30 & & 30 & & \\
\hline C108 & 470558 & 4478720 & XKS & 50 & & & & 85 & & 20 & & \\
\hline C110 & 471694 & 4482963 & XKS & 25 & & & & & 120 & & & 20 \\
\hline C111 & 472000 & 4483403 & XKS & & & & & 25 & 55 & & & \\
\hline C117B & 474053 & 4483669 & XKS & 55 & & & & 80 & & 35 & & \\
\hline C121 & 475042 & 4482626 & XQS & 85 & & & & & & & & \\
\hline C122 & 475531 & 4482644 & $\mathrm{XBS}$ & & & & & 130 & & & & \\
\hline C126 & 475980 & 4483996 & XKS & 55 & & & & 120 & & & & \\
\hline C130 & 472840 & 4484427 & XKS & & & & & 50 & & & & 25 \\
\hline C133 & 472811 & 4485927 & XKS & & & & & 85 & 55 & & & \\
\hline $\mathrm{C} 134 \mathrm{~A}$ & 472679 & 4485070 & XKS & 60 & & & & 90 & & & & \\
\hline C135B & 472295 & 4484694 & XKS & 55 & & & & 80 & & & & 130 \\
\hline C138B & 469858 & 4485392 & XKS & & & & & 65 & & & & 135 \\
\hline
\end{tabular}

$\mathrm{XQS}=$ Quartzofeldspathic mica schist, $\mathrm{XKS}=$ Knotted mica schist, $\mathrm{XBS}=$ Porphyroblastic biotite schist, $\mathrm{N}=\mathrm{No}$ information available about the geographic coordinates.

The combined FIA trend data for garnet and staurolite is shown in figure $5(\mathrm{~d})$. The other porphyroblastic phases in which FIAs were measured were andalusite and cordierite, with seven measurements in the former and 14 in the latter. Their trends are given in table 1 and are shown on a rose diagram in figure 5 (e and f). A few samples maintain differentiated crenulation cleavages that have been overgrown by the porphyroblasts where the asymmetry of the crenulated cleavage can be determined. The crenulated cleavages consist of quartz and ilmenite grains, while the differentiated crenulation cleavages predominantly contain ilmenite grains. The intersection between the crenulated and crenulation cleavages can be determined, when viewed in three dimensions, and is called a pseudo-FIA (pseudo-FIA). The actual FIA is formed during porphyroblast growth and these samples are defined by the curvature of the differentiated crenulation cleavage. All measured trends were plotted on a rose diagram as shown in figure 5.

\subsection{Dating of FIA sets}

To determine the age of the four FIA sets measured in the area, 30 samples were selected for monazite dating. Polished thin sections were made for use in the JEOL JXA-8300 Superprobe. Only 11 samples out of the 30 selected contained monazite grains large enough for precise age calculations. Detailed pre-dating maps were produced from each polished thin section to accurately locate monazite grain and their textural setting. The analytical procedure is outlined in table 2 . The samples were analysed with a 1-2 micron meter diameter beam at $15 \mathrm{kv}$ and $200 \mathrm{nA}$. The collimators were opened to a maximum $(3 \mathrm{~mm})$ and the PHA settings were optimized as well. In all these measurements, $\pi \mathrm{rz}$ matrix corrections were performed using standard $\mathrm{Pb}, \mathrm{U}$, Th, and $\mathrm{Y}$ concentrations in combination with the preset values for other elements (P 33.3, La 14.5, Ce 26, Pr 2.6, Nd 10.3, Sm 1.5, Gd 1.48, Dy 0.82 , Si 0.25 , Ca 0.55 wt.\% oxides). Interference corrections of $\mathrm{Th}$ and $\mathrm{Y}$ on $\mathrm{Pb} \mathrm{M} \alpha$ and $\mathrm{Th}$ on $\mathrm{U}$ M $\beta$ were executed as in Pyle et al. (2002). An internal standard monazite from Manangotry in Madagascar of $545 \pm 2 \mathrm{Ma}$ (Paquette et al. 1984) was analysed three times before and after each analytical session. Chemical ages were calculated as described in Montel et al. (1996). Geologically significant age information can be derived by assuming low amounts of common $\mathrm{Pb}$ (e.g., Parrish 1990; Gaidies et al. 2008) and slow diffusion rates for $\mathrm{Th}, \mathrm{U}$ and $\mathrm{Pb}$ in monazite (Cherniak et al. 2004). The samples were chosen based on FIA set and the grains were isolated and clustered according to their age, textural setting and whether any chemical zonation was present (Cihan et al. 2006). This would potentially reduce any error and make the age information reliable (Montel et al. 1996; Pyle et al. 2005; Gaidies et al. 2008). Dates and errors were determined by mean age with standard errors at $95 \%$ confidence level for a cluster of spots analysis within a single age domain or grain. Ages were 
(a)
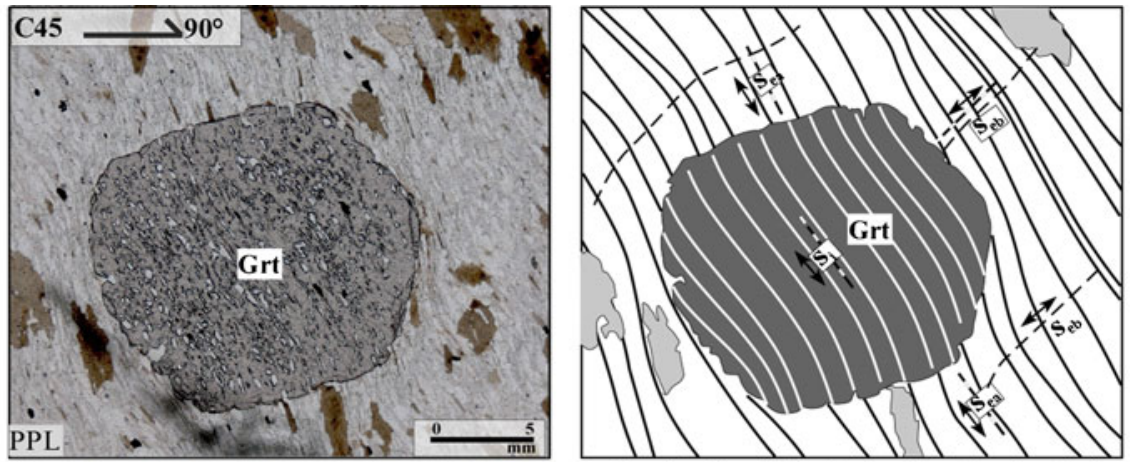

(b)
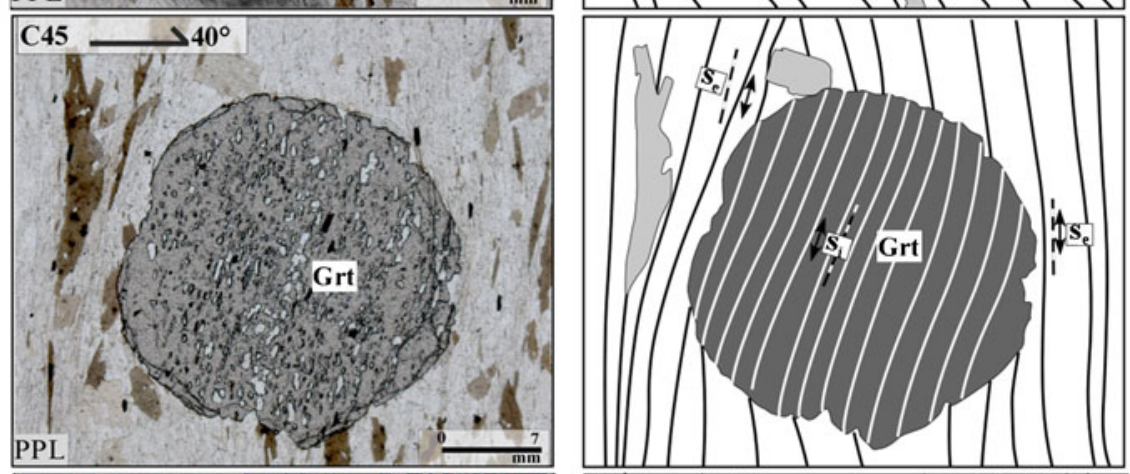

(c)
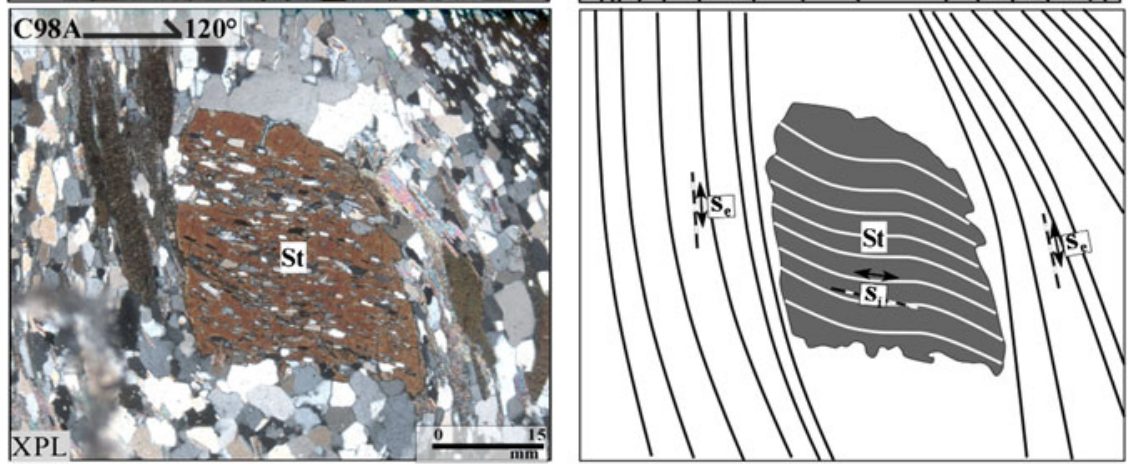

(d)
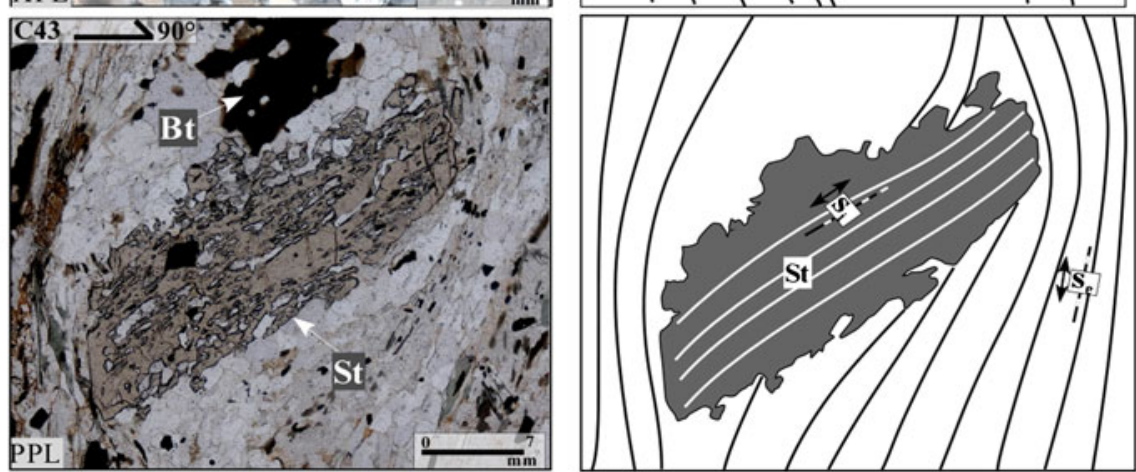

Figure 4. Representative photomicrographs and line diagrams of vertical thin sections of different samples illustrating variation in inclusion trail geometry, truncation and continuity with the matrix foliation. (a, b) Garnet porphyroblast preserves an oblique foliation that curves clockwise to sub-vertical $\left(\mathrm{S}_{\mathrm{i}}\right)$. (c, $\left.\mathbf{d}\right)$ Garnet porphyroblast preserves a sub-horizontal foliation $\left(\mathrm{S}_{\mathrm{i}}\right)$ truncated and curved by a sub-vertical with an anti-clockwise asymmetry. (e, f) Staurolite porphyroblast preserves a sub-horizontal foliation $\left(\mathrm{S}_{\mathrm{i}}\right)$ that is truncated with that in the matrix and has an anti-clockwise curvature. (g, h) Staurolite porphyroblast with inclusion trails completely truncated by those within the matrix. A slightly anti-clockwise curvature was observed in the rim or from the porphyroblast into the matrix in these porphyroblasts. Sample numbers, strikes and way up of the vertical thin sections are shown in the upper left corner (thick single barbed arrow). PPL: plane polarized light; XPL: cross polarized light, $\mathrm{S}_{\mathrm{e}}$ : external foliation, $\mathrm{S}_{\mathrm{i}}$ : Internal foliation, St: staurolite, Bt: biotite, Grt: garnet (after Shah 2009). 


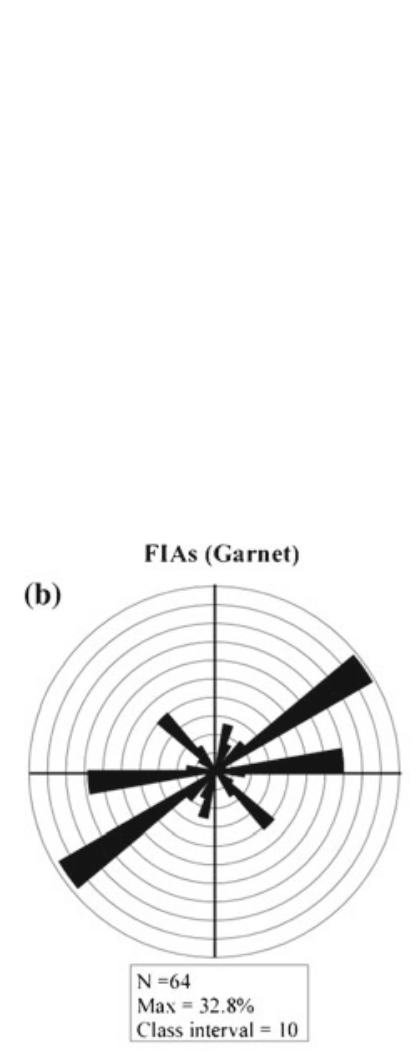

(a)

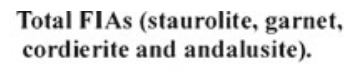
cordierite and andalusite).
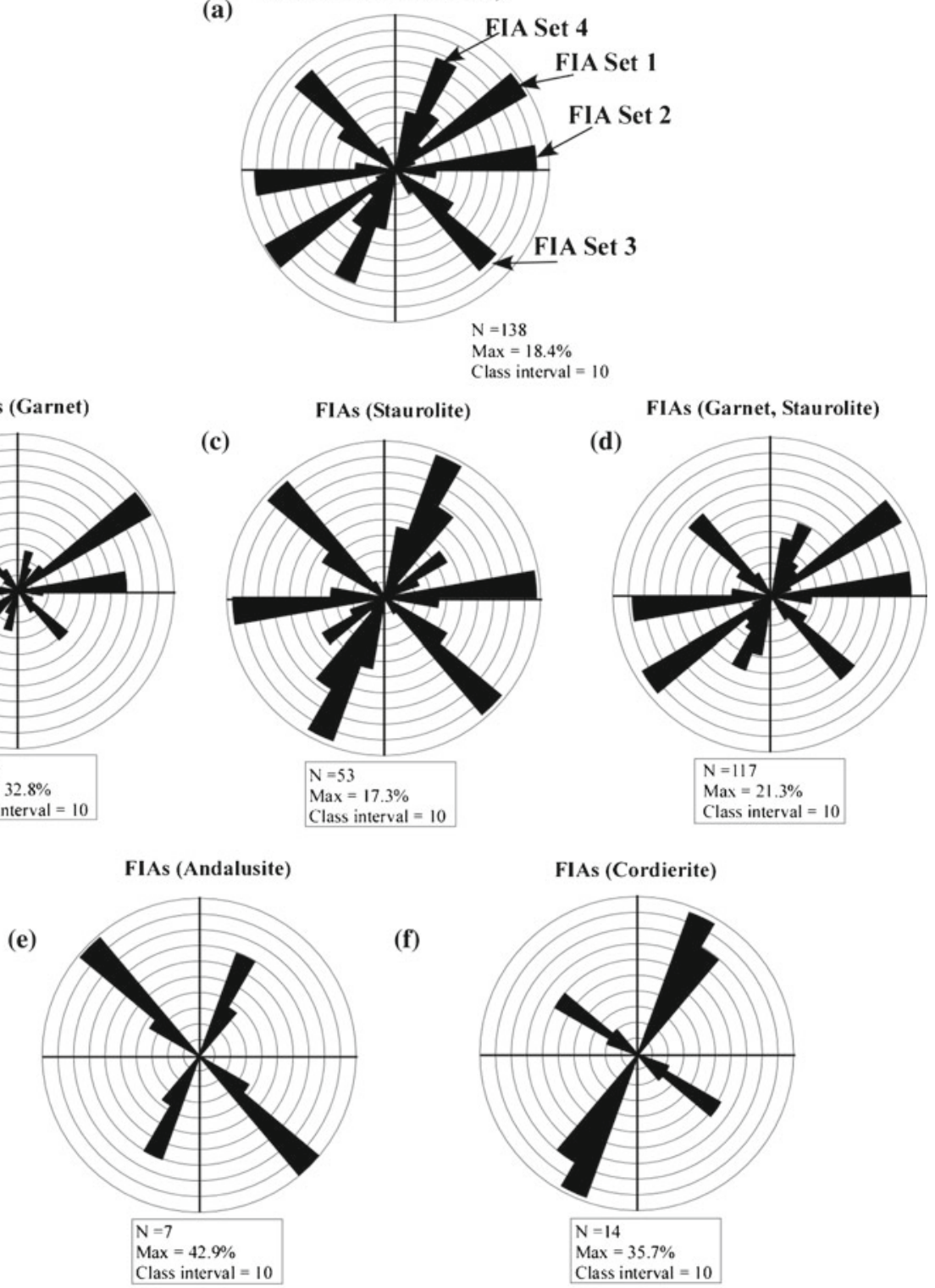

(f)

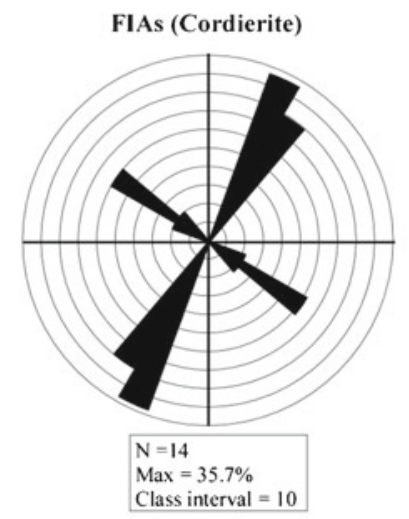

Figure 5. (a) Equal area rose plot of all FIA trends measured from garnet, staurolite, andalusite and cordierite. Four peaks occur at $25^{\circ}, 55^{\circ}, 85^{\circ}$ and $135^{\circ}$. (b) Garnet FIAs (c) staurolite FIAs, (d) garnet plus staurolite FIAs, (e) andalusite FIAs, and (f) cordierite FIAs.

then calculated for all the grain populations analyzed and plotted using software Isoplot (Ludwig 1998). Three samples contained monazite grains big enough to extract valuable age information in garnet porphyroblasts. Six contained suitable monazite grains in staurolite porphyroblasts. Two contained suitable monazite grains in andalusite plus cordierite.

\subsection{Dating of foliations within porphyroblasts}

Unless otherwise stated, monazite inclusions lie with the foliation defining the FIA set for that mineral phase. All rocks contain biotite, muscovite, plagioclase and quartz with accessory phases ilmenite and apatite. Quartz and apatite and rarely muscovite, biotite, chlorite inclusions are always present within both garnet and staurolite porphyroblasts. Monazite is always present within staurolite but not necessarily in garnet phases.

\subsubsection{Sample C117}

Garnet (FIA set 1) and staurolite (FIA set 2) inclusion trails are always truncated by the matrix 
Table 2. Analytical set-up for monazite analyses on the JEOL JXA-8200, Electron Probe Micro Analyzer (EPMA) at the Advanced Analytical Centre, JCU Townsville, Australia.

\begin{tabular}{lccccl}
\hline Element & X-ray & $\begin{array}{c}\text { Crystal- } \\
\text { spectrometer }\end{array}$ & $\begin{array}{c}\text { Peak time } \\
(\mathrm{s})\end{array}$ & $\begin{array}{c}\text { Background } \\
\text { time }(\mathrm{s})\end{array}$ & \multicolumn{1}{c}{ Standard } \\
\hline $\mathrm{P}$ & $\mathrm{Ka}$ & TAP & 20 & 10 & Ce phosphate \\
$\mathrm{Pb}$ & $\mathrm{Ma}$ & PETJ & 180 & 90 & PbSiO3a $^{\mathrm{a}}$ \\
$\mathrm{La}$ & $\mathrm{La}$ & LIFH & 10 & 5 & La phospahte $^{\mathrm{b}}$ \\
$\mathrm{U}$ & $\mathrm{Mb}$ & PETJ & 180 & 90 & Uranium $^{\mathrm{a}}$ \\
$\mathrm{Th}$ & $\mathrm{Ma}$ & PETJ & 90 & 45 & ThO2 \\
$\mathrm{Y}$ & $\mathrm{La}$ & TAP & 60 & 30 & Yttrium phosphate \\
$\mathrm{Ce}$ & $\mathrm{La}$ & LIFH & 10 & 5 & Ce phosphate \\
$\mathrm{Ca}$ & $\mathrm{Ka}$ & PETJ & 20 & 10 & Wollastonite \\
$\mathrm{Si}$ & $\mathrm{Ka}$ & TAP & 20 & 10 & PbSiO3 \\
$\mathrm{Pr}$ & $\mathrm{Lb}$ & LIFH & 20 & 10 & Pr phosphate \\
$\mathrm{S}$ & $\mathrm{Ka}$ & PETJ & 30 & 15 & BaSO4 \\
$\mathrm{Nd}$ & $\mathrm{Lb}$ & LIFH & 10 & 5 & Nd phosphate \\
$\mathrm{Sm}$ & $\mathrm{Lb}$ & LIFH & 40 & 20 & Sm phospahte \\
$\mathrm{Gd}$ & $\mathrm{Lb}$ & LIFH & 40 & 20 & Gd phospahte \\
$\mathrm{Dy}$ & $\mathrm{Lb}$ & LIFH & 40 & 20 & DY phospate \\
\hline
\end{tabular}

${ }^{\mathrm{a}}$ Astimex, ${ }^{\mathrm{b}}$ Sealed Xe detectors, ${ }^{\mathrm{c}}$ Taylor, ${ }^{\mathrm{d}} \mathrm{Pb}$-free synthetic from J. Pyle (Rennselaer Polytechnic Institute, USA).

Table 3. Summary of ages derived from monazites preserved within the porphyroblasts and the matrix phases of abovementioned samples (staurolite data from Sanislav and Shah 2010).

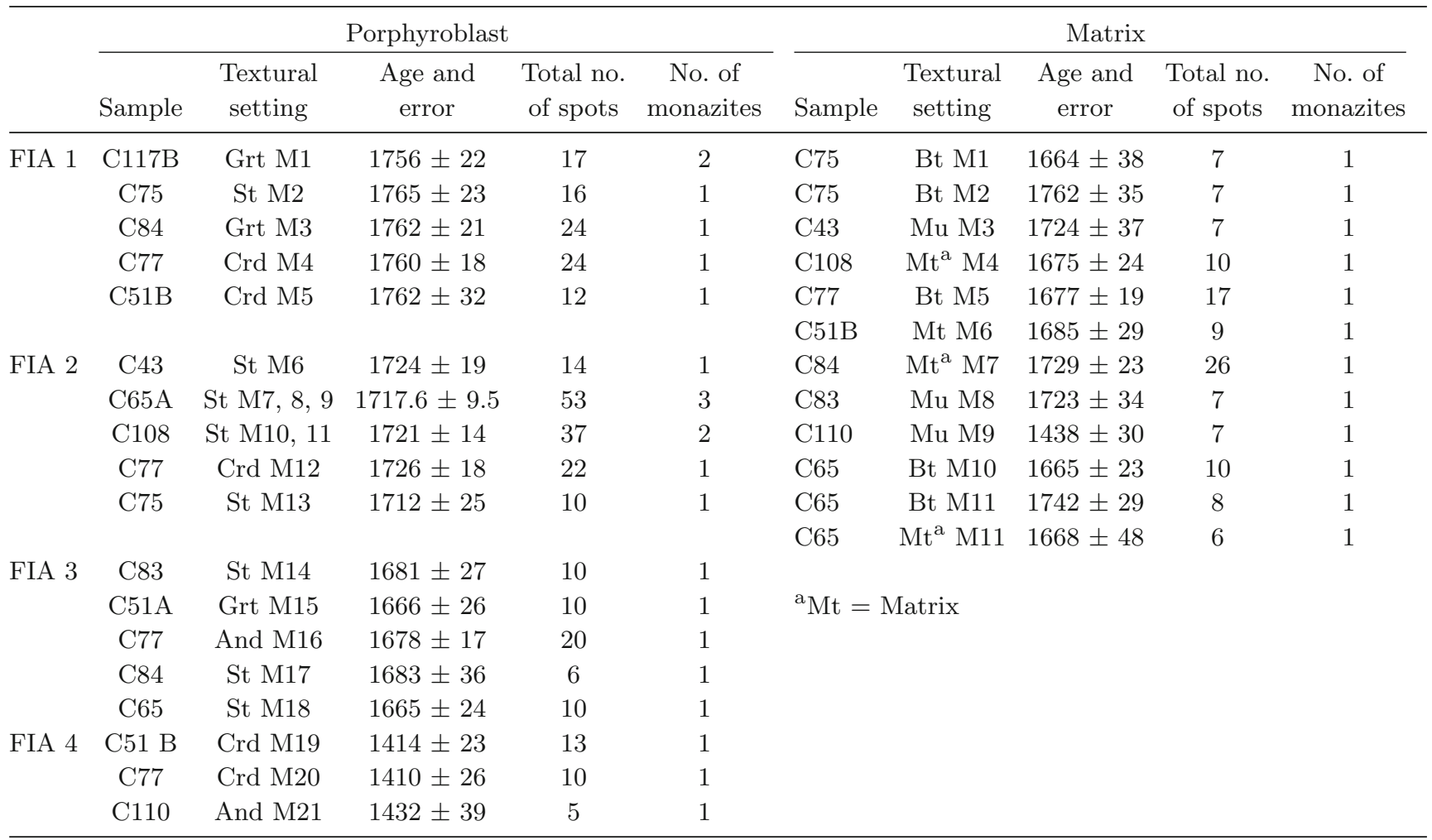

foliation. Extra minor phases include zircon and xenotine. Two monazite inclusions within garnet have given a mean age spread of $1756 \pm 22 \mathrm{Ma}$ (see tables 3 and 4; figure 6).

\subsubsection{Sample C84}

Garnet and staurolite inclusion trails are always truncated by the matrix foliation. Extra accessory 


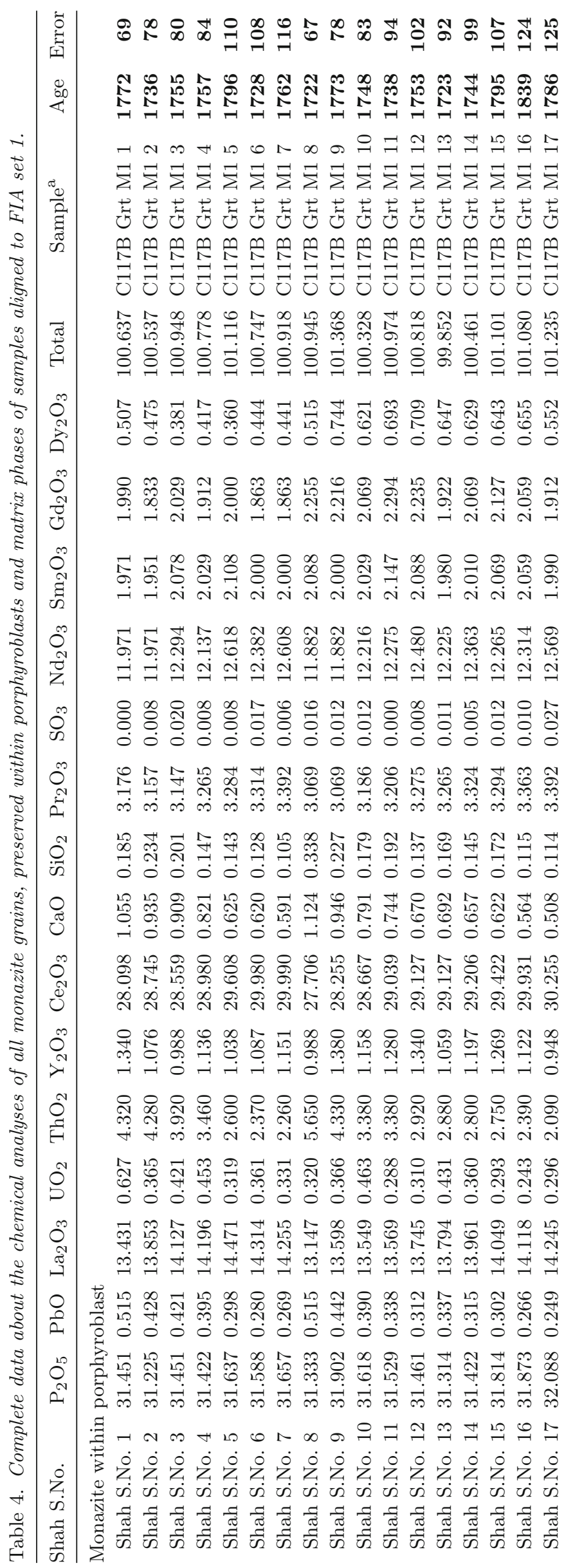

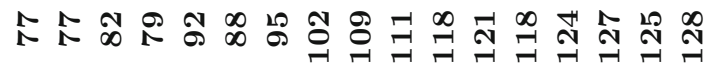
品

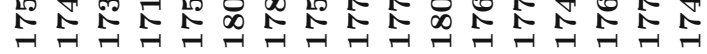
十

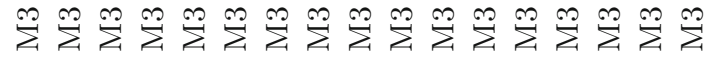

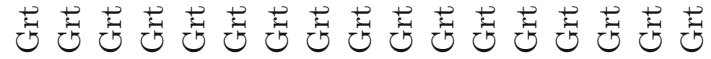

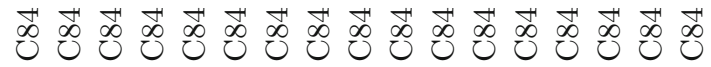

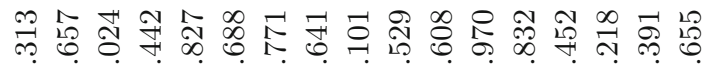

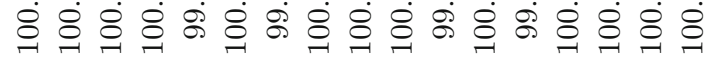

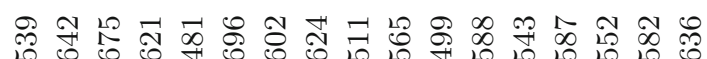

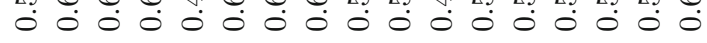

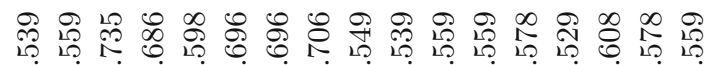

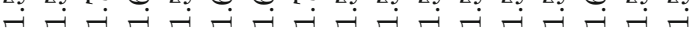

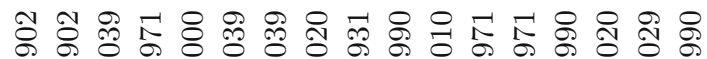

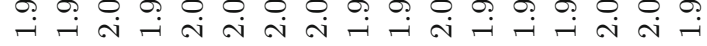

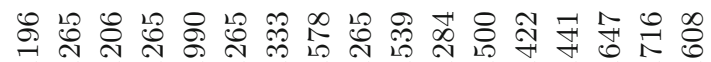

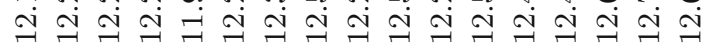
\& 용 궁 \&

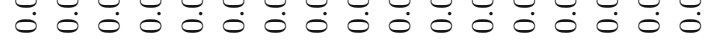

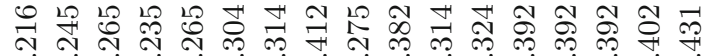

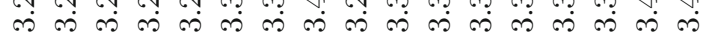

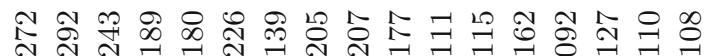

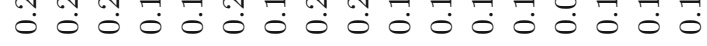

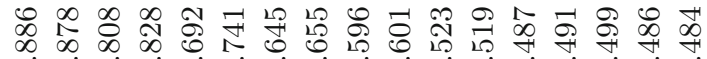

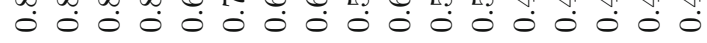

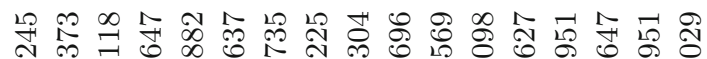
๙่)

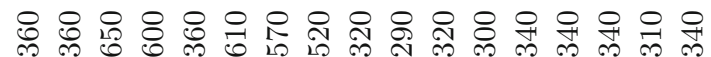

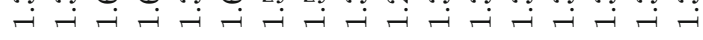

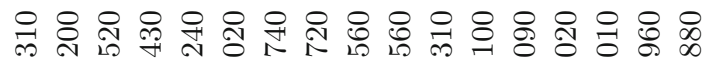

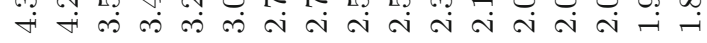

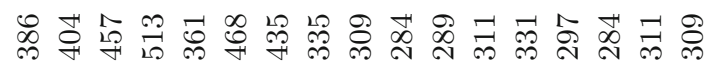

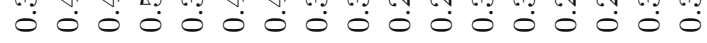

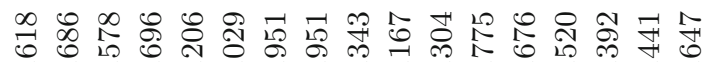

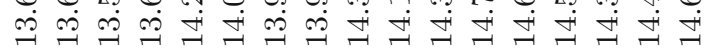

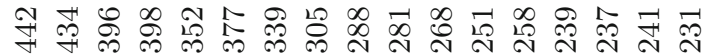

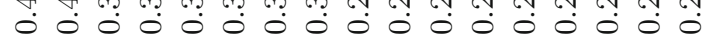

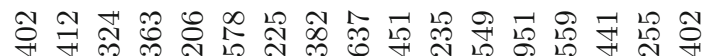
मे में में में

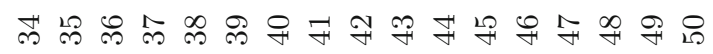

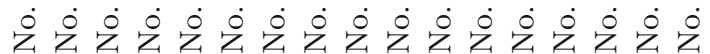

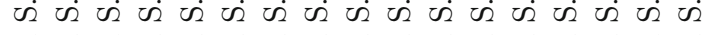

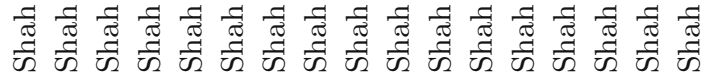




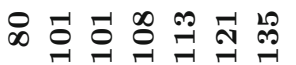

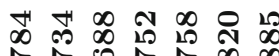

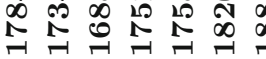

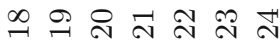

$\sum_{i}^{m} \sum_{i}^{m} \sum_{i}^{m} \sum_{i}^{m}$

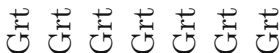

范

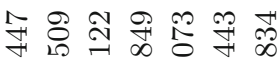

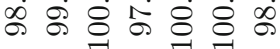

ำ $\because \dot{0} 0 \dot{0} \dot{0} 0 \dot{0}$

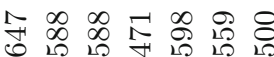

$-\dot{-i}-\dot{-1}-$

융 \& \& \&

i

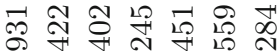

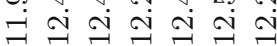

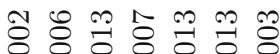

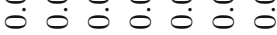

\&

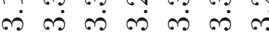

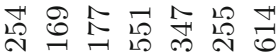
ণั0

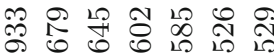

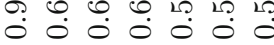

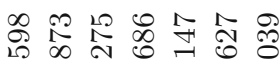

N

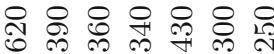

-

왕ㅇㅇ요용ㅇㅇㅇ m

לํำ

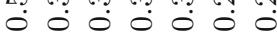

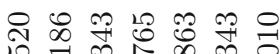

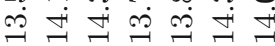

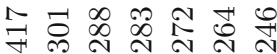
००

ఋి

कें में लें ले

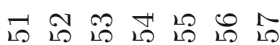

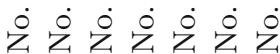

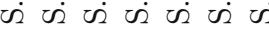

ฮี డี ฮี ฮี ఠี ฮี

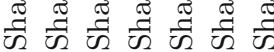

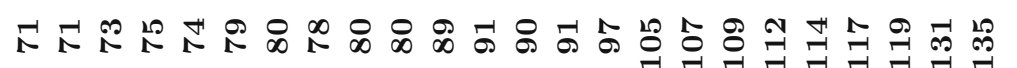

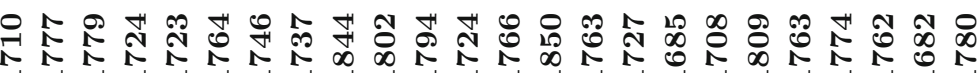

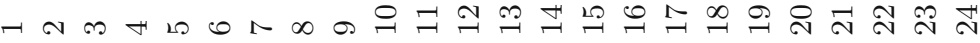

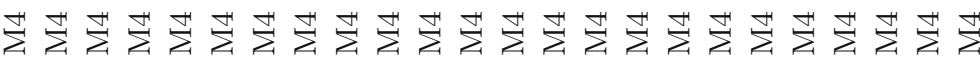

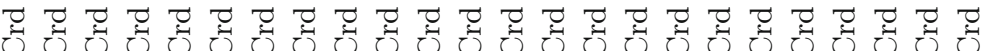

N $N$ N

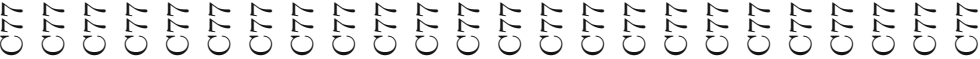

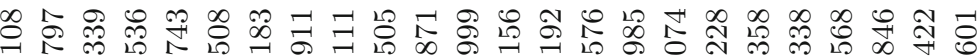

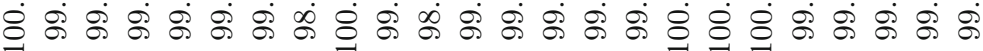

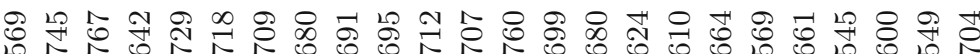

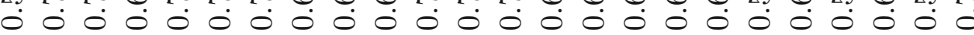

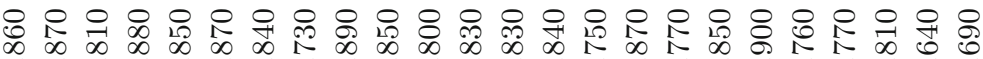

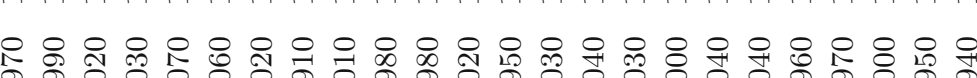

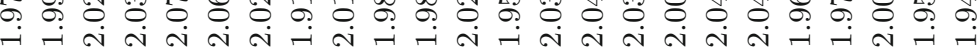

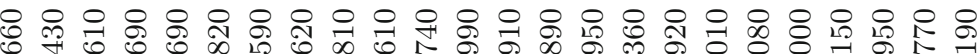

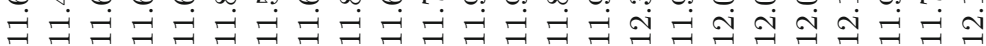
용 范

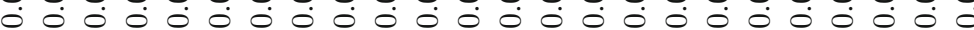

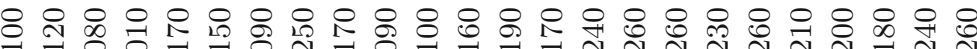

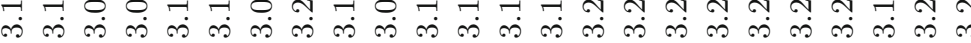
m

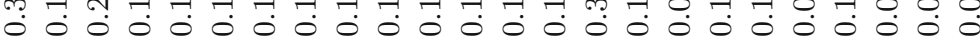

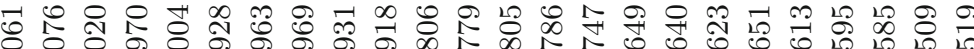
-

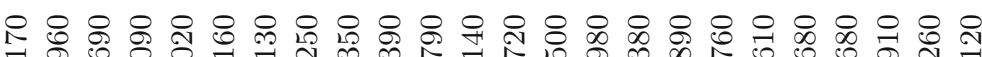

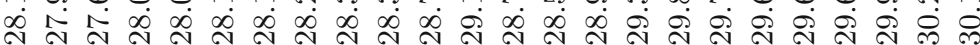

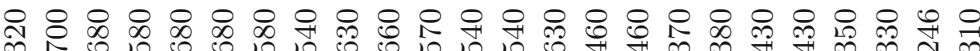
ن 융

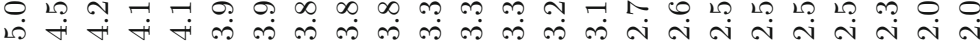

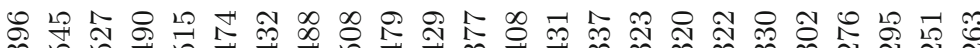

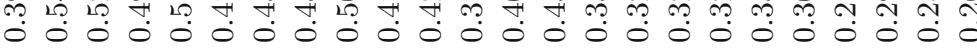

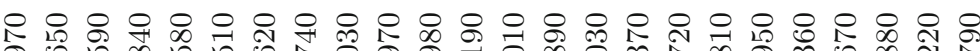

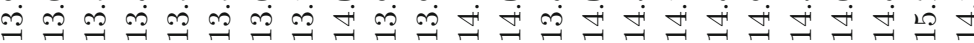

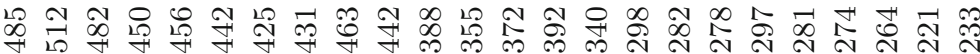

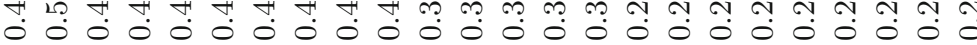

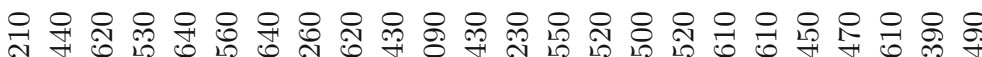

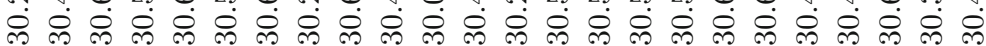

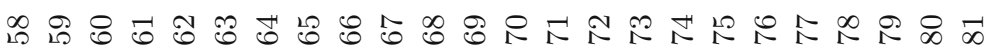
$\dot{z} \dot{z} \dot{z} \dot{z} \dot{z} \dot{z} \dot{z} \dot{z} \dot{z} \dot{z} \dot{z} \dot{z} \dot{z} \dot{z} \dot{z} \dot{z} \dot{z}$

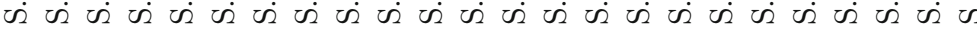

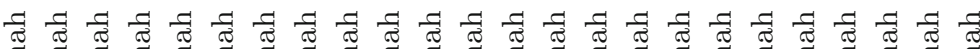

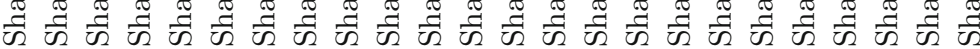

ลี $\infty \dot{\sigma} \theta$ ๑ำ

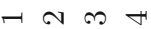

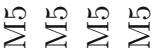

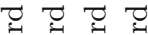
ठठ ठठ ठ

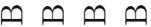

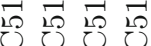

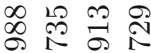
$\dot{8} \dot{8} \dot{8}$ 궁 0 \%

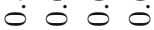
웅융은 옴 -i 융 유요 \& 거 옹 유은 왁 บำ

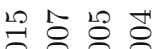

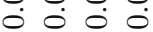
욕유요윽 तो को को 我 \& ००

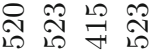

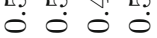
읭ㅇㅇ ते $\overrightarrow{\mathrm{N}} \stackrel{\mathrm{N}}{\mathrm{i}}$ 羿 용 8

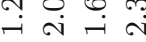

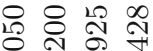
त $\rightarrow$ : 足

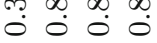
\& 융 \&

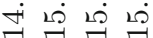

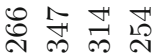
$\circ \div 00$ \& \& \& मे ले

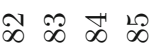
$\dot{0} \dot{0} \dot{2} \dot{z}$

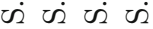

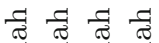
近 $\frac{\overrightarrow{1}}{\pi}$ 


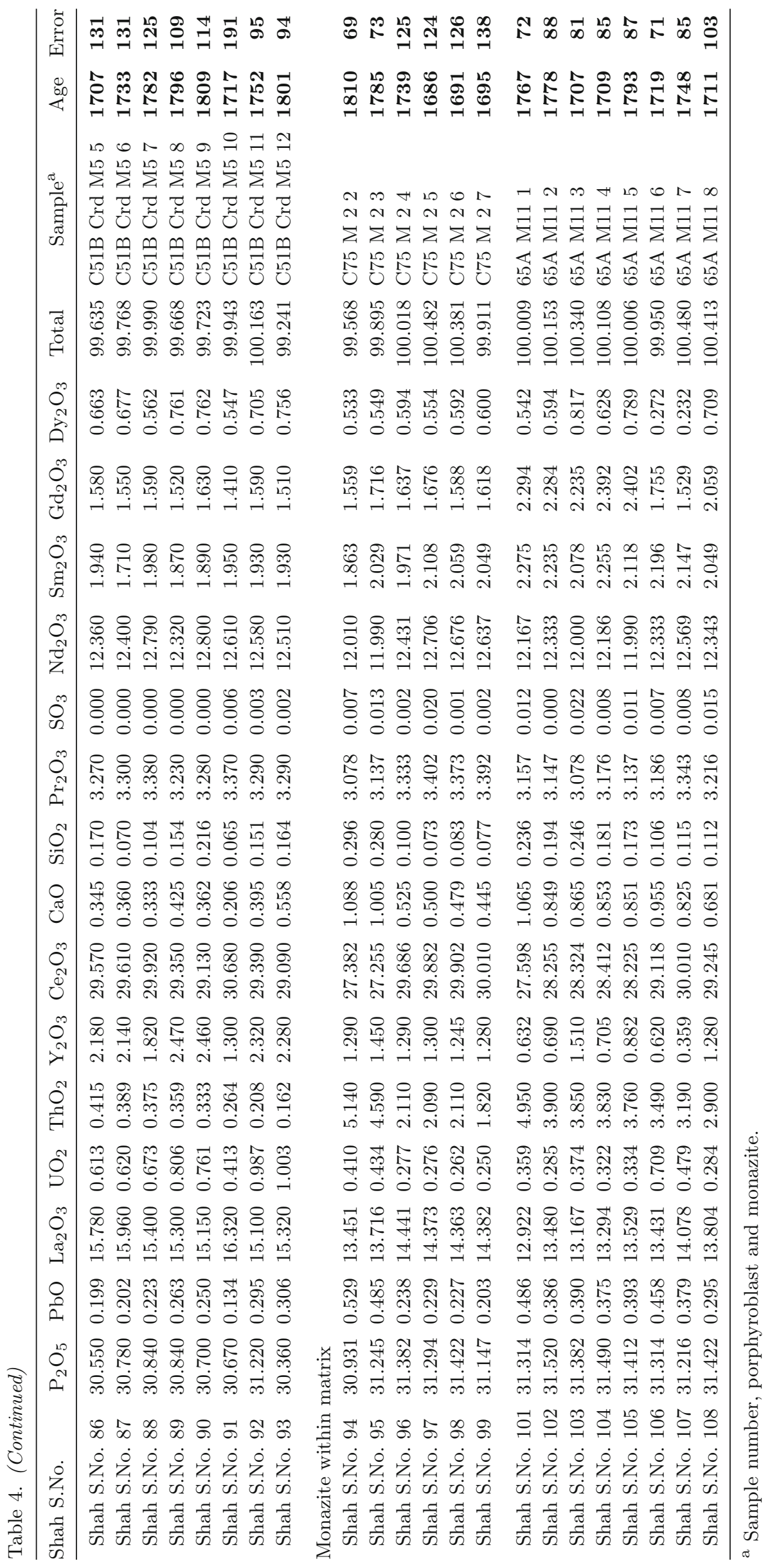


(a)

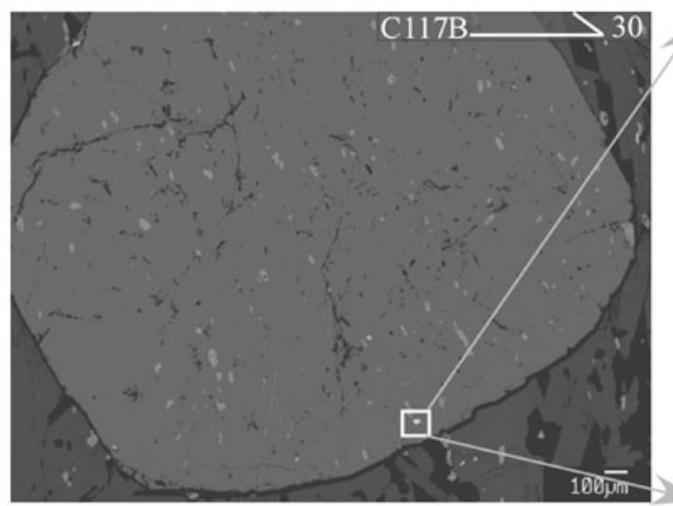

(c)

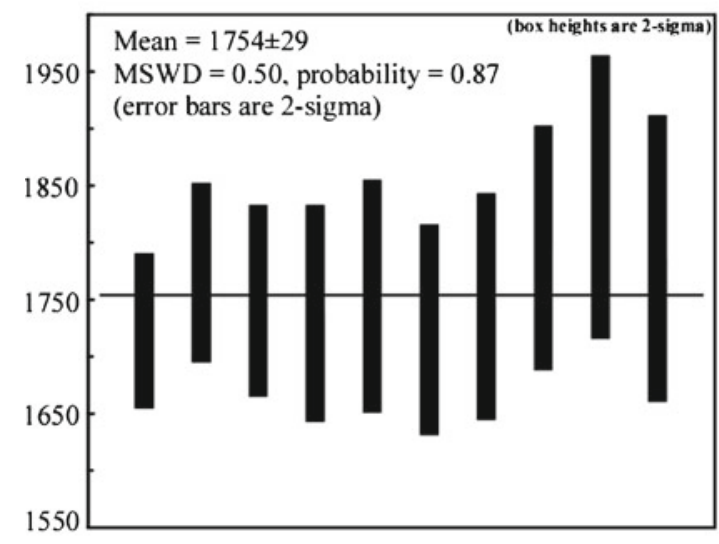

(b)

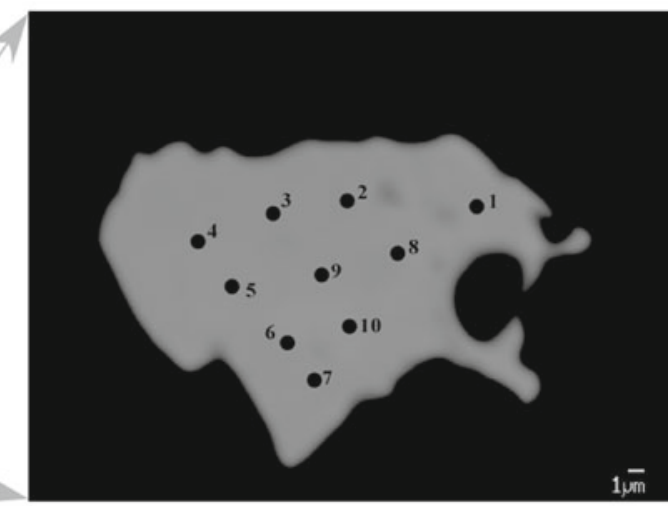

(d)

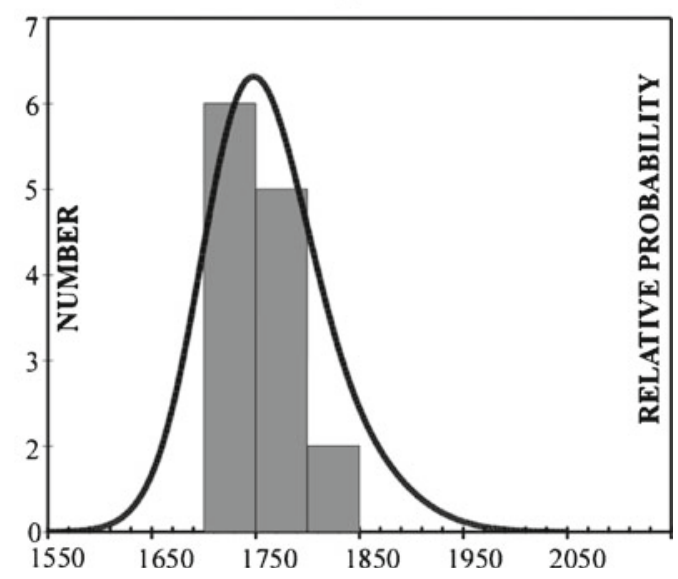

Figure 6. (a) Back scatter image shows the garnet porphyroblast which preserves a single monazite grain lying parallel to the orientation of its foliation. A mean age of $1754 \pm 29 \mathrm{Ma}$ is calculated from a total of 10 spots analyzed. (b) Enlarged view of the monazite grain with black spots showing the location of each analysis. In (c) the weighted average age plot is shown, created by using Isoplot software (Ludwig 1998) and in (d) the probability density plot is shown.

phases include magnetite, zircon, xenotine and monazite. A total of two monazite grains were dated from this sample. One within garnet with an age spread of $1762 \pm 21 \mathrm{Ma}$ (FIA set 1) and the other grain within staurolite (FIA set 3, Sanislav and Shah 2010) with an age spread of $1683 \pm 36 \mathrm{Ma}$ (see tables 3 and 4).

\subsubsection{Sample C77}

This sample contains andalusite and cordierite porphyroblasts, but no garnet and staurolite porphyroblasts, and the extra accessory phases of magnetite and xenotine. Inclusion trails in cordierite are continuous with the matrix foliation and preserve FIA set 4 . Cordierite contains a pseudo-FIA belonging to set 3 and FIA set 4 . Andalusite contains inclusion trails defining FIA set 3 that are truncated by foliations within both the matrix and the youngest foliation in cordierite. Inclusions in both porphyroblastic phases include staurolite and garnet although the latter is rare.
Three monazite grains enclosed within cordierite (2) and andalusite (1) porphyroblasts were dated. One monazite grain within a crenulated cleavage seam gives a pseudo-FIA set 3 age of $1678 \pm$ 17 Ma within cordierite. The andalusite porphyroblast preserves the same foliation as FIA 3. The $1760 \pm 18$ and $1726 \pm 18 \mathrm{Ma}$ ages were derived from their monazites (see tables 3-6).

\subsubsection{Sample C110}

Also contains andalusite and cordierite porphyroblasts. Extra accessory phases are dominated by magnetite, xenotine, zircon and baddeleyite. Andalusite preserves FIA set 4 and its inclusion trails are continuous with the matrix foliation. Inclusions within andalusite include staurolite and cordierite. A single monazite grain found in andalusite gave an age of $1432 \pm 39 \mathrm{Ma}$ (see tables 3 and 7 ) for the foliation preserved as inclusion trails. 


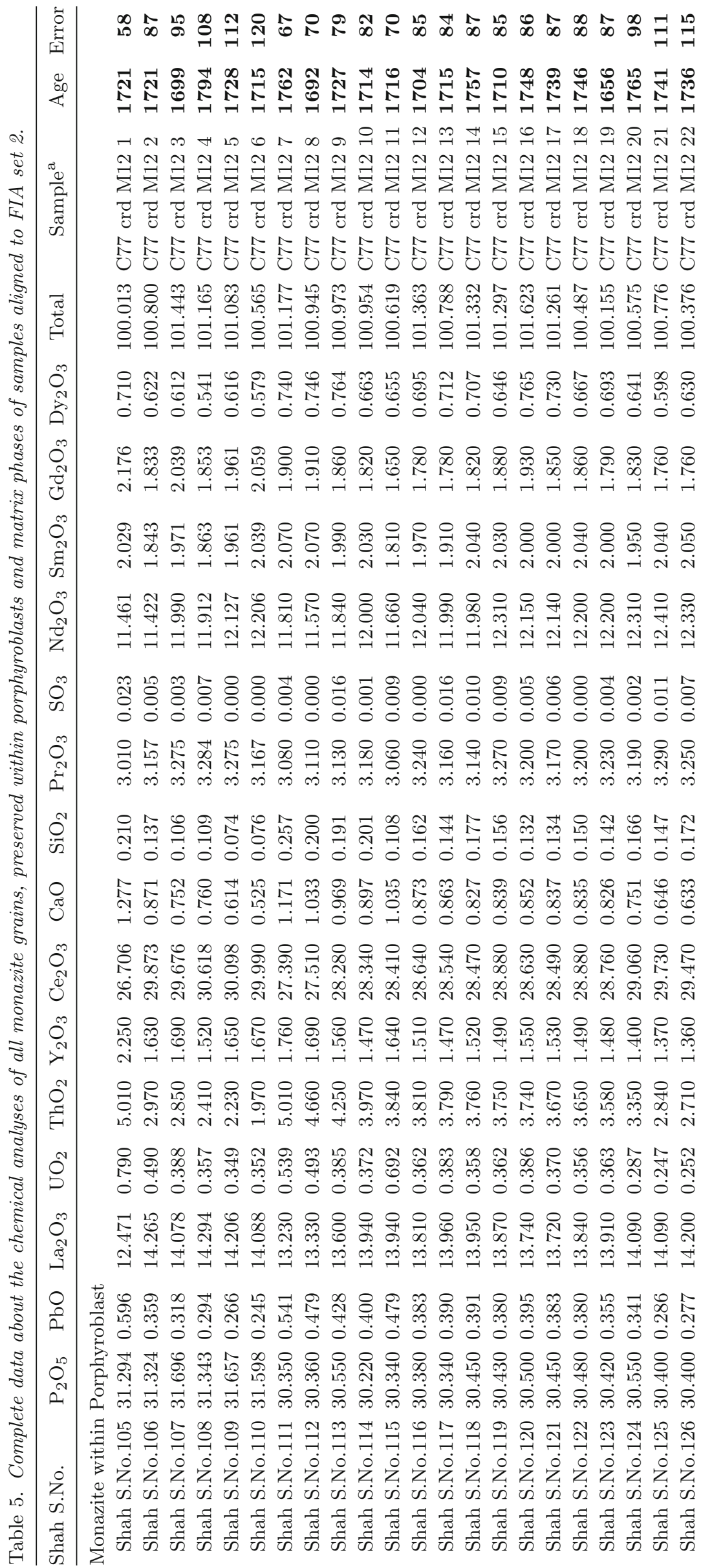

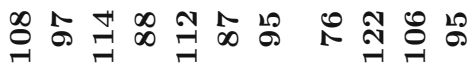

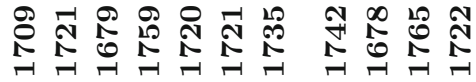

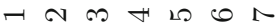
$\sum_{i}^{m} \sum_{i}^{m} \sum_{n}^{m} \sum^{m} \sum^{m}$

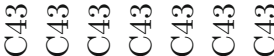

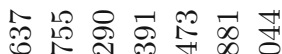
\& $8 \dot{0} \dot{0} \& \dot{0} \dot{0}$

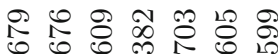

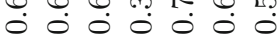

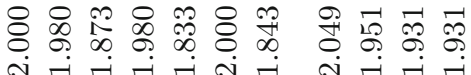

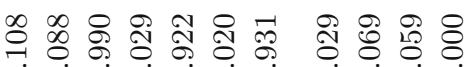
A

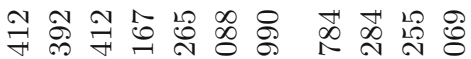

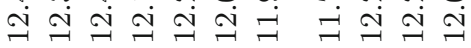

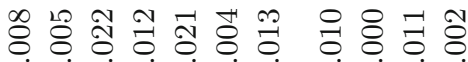

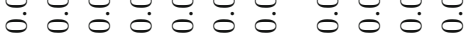

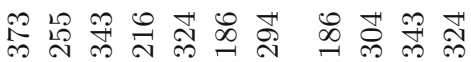

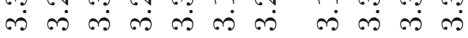

กิ

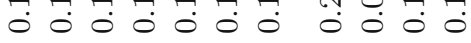

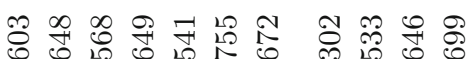
$\circ 0000000$

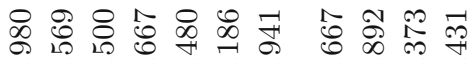

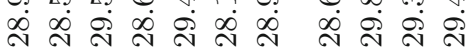

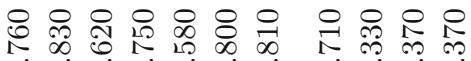

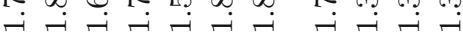

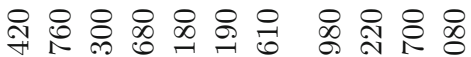
ง

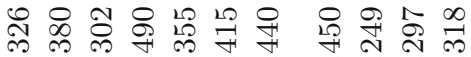

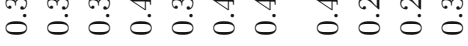
\&규.

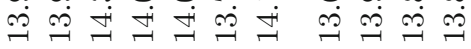

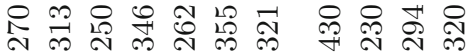
ণู

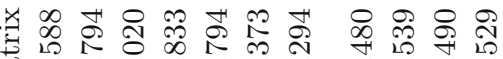

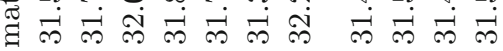

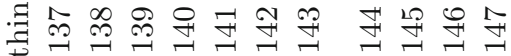

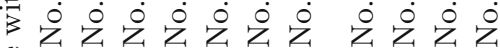
的的的的的的的

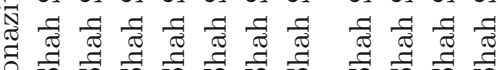
0
0 


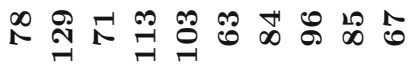

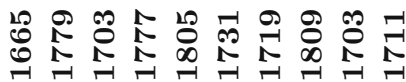

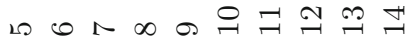

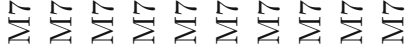

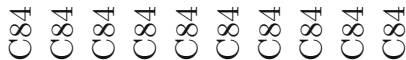

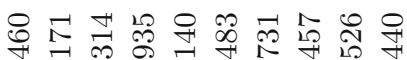
ஓं $\dot{8} \dot{8} \dot{8} \dot{8} \dot{0} \dot{0} \dot{0}$

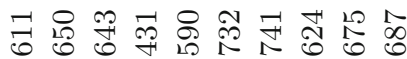

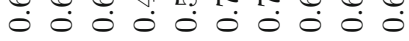

N $\begin{aligned} & \Re \\ & \infty\end{aligned}$

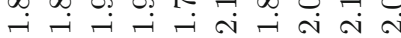

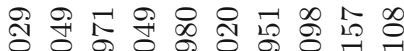

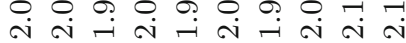

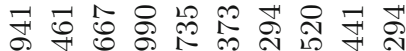

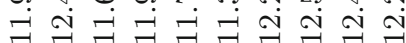

๖ \& \&

బ

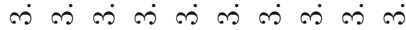

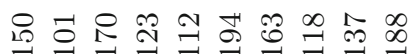

:

대ำㅇำ ○

กิ i

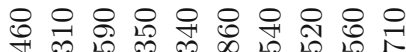
-

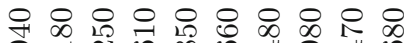

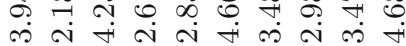

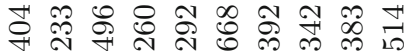
० 0 :

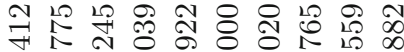

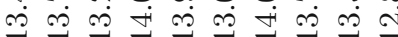

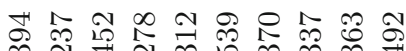

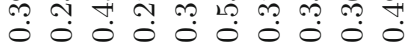

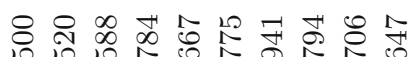

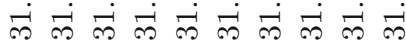

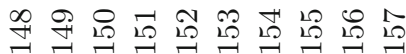

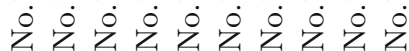

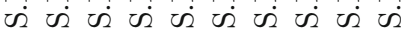
สี สี สี สี สี สี สี สี สี สี

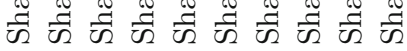

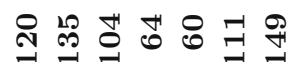

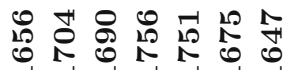
$\sum^{\infty} \sum^{\infty} \sum^{\infty} \sum^{\infty} \stackrel{\infty}{\Sigma}^{\infty}$

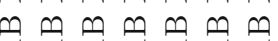
हु Ұ

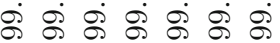

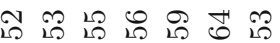

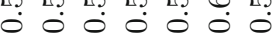

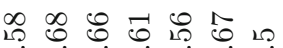
ن

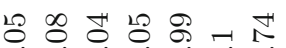
ํ จ

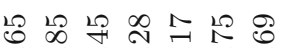
ำ ำ ำ ำ ำ ๗ి $\infty$ 가요 $\infty$ 느

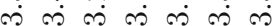

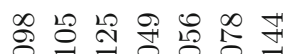

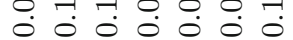

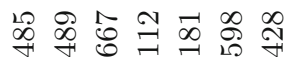
○े 0 ○

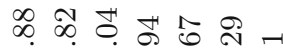
ค่

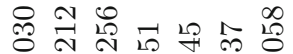
药 $\infty \stackrel{-1}{\infty}$ ๑ ஓ ชิ ชิ வ 光

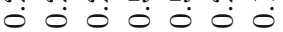

년

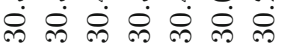

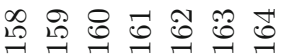
它完完完完完完

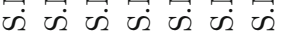
สี สี तี तี तี तี तี 光 $\frac{\pi}{\pi} \frac{\pi}{\pi} \frac{\pi}{\pi} \frac{\pi}{\pi} \frac{\pi}{\pi}$

\subsubsection{Sample C55A}

This sample also contains cordierite plus minor xenotine. Garnet preserves inclusion trails defining FIA set 3 that are truncated by the foliation in cordierite and the matrix. Cordierite contains FIA set 4 trails that are continuous with those present within the matrix. Staurolite is also included in cordierite. A single monazite dated at $1666 \pm 26 \mathrm{Ma}$ from this sample is located within garnet (see tables 3 and 6). No monazite grains were found in cordierite.

\subsubsection{Sample C51B}

This sample also contains cordierite porphyroblasts with inclusion trails defining FIA set 4 that are continuous with foliations preserved within the matrix. Staurolite and andalusite are also present as inclusions. Two grains of monazite dated at an average age of $1412 \pm 17 \mathrm{Ma}$ lie within the foliation preserved within the cordierite (see tables 3 and 7). Another monazite was dated at $1762 \pm$ $32 \mathrm{Ma}$, within the same foliation (see tables 3 and 6$)$.

\section{Dating of matrix foliations}

The foliations within porphyroblasts are completely truncated by those within the matrix phases in all samples except C110. Consequently, monazite ages in the matrix cannot be used to date FIAs. They were dated to see what relics of the deformation history determined from the FIA succession were preserved in the matrix and whether there was any evidence for deformation occurring between the Colorado and Berthoud orogenies.

\subsection{Sample C83 (FIA 2 in garnet and 3 in staurolite)}

A single monazite grain parallel to the main matrix foliation $\left(\mathrm{S}_{\mathrm{e} 1}\right)$ of this sample has an age of $1723 \pm$ $34 \mathrm{Ma}$ (see tables 3 and 5). This sample preserves FIA set 2 within garnet and set 3 in staurolite porphyroblasts (figure 7).

\subsection{Sample C75 (FIA 1 and 2 in staurolite)}

Three foliations in the matrix $\left(\mathrm{S}_{\mathrm{ea}}-\mathrm{S}_{\mathrm{ec}}\right)$ are shown in figure 8. A $1664 \pm 38 \mathrm{Ma}$ age was derived from a monazite grain lying sub-parallel to $\mathrm{S}_{\mathrm{e} 2}$ (figure 9). Another monazite grain that lay orthogonal to this 


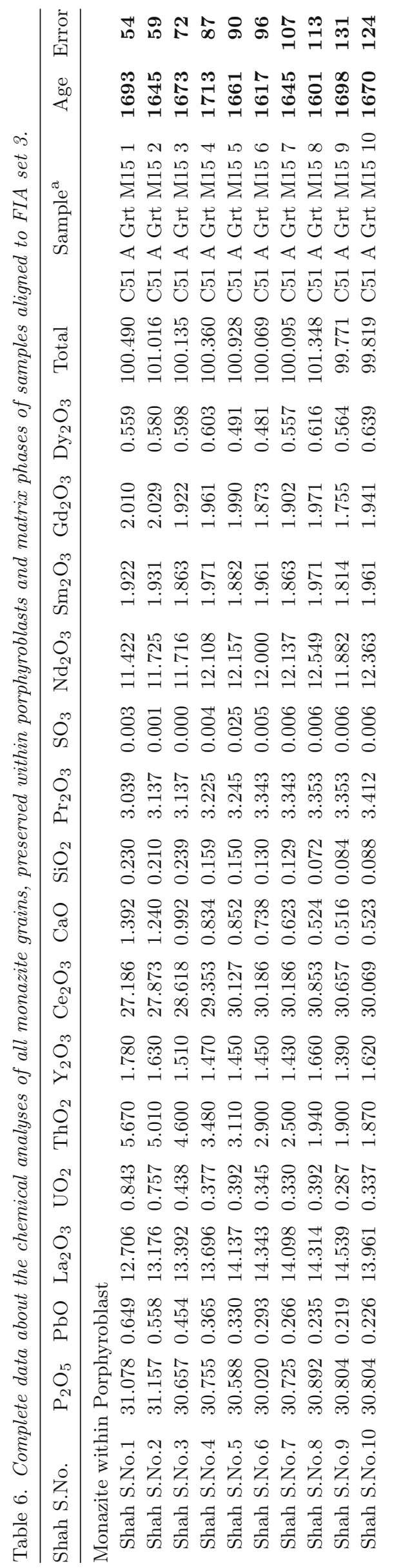

ஜ

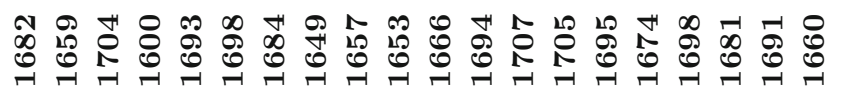
$\neg \alpha m+$ n

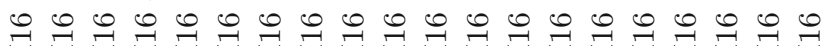

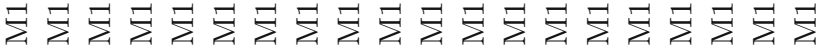

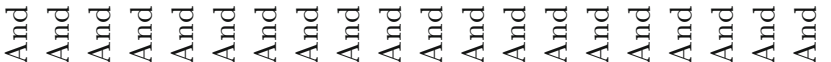

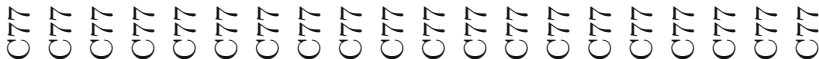

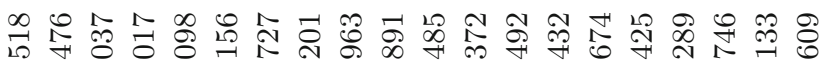

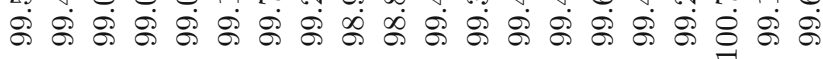

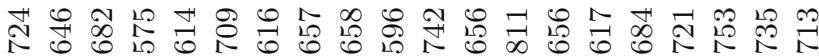

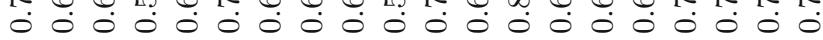

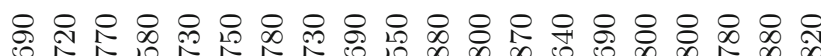

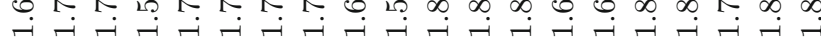
\& \& 융요

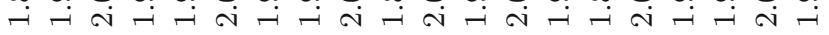

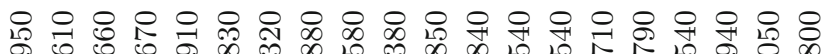

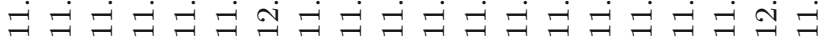

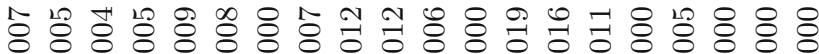

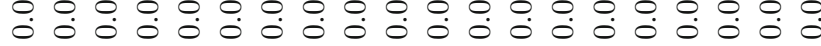

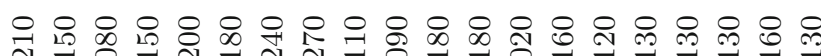

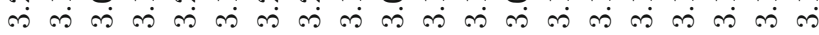

곡

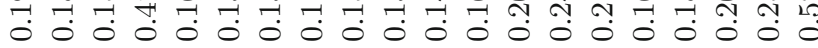
유 승

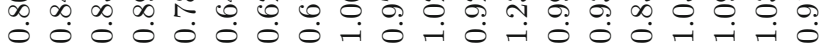
규

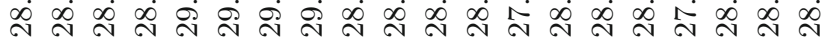

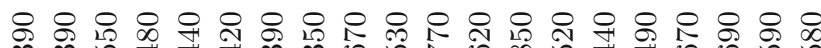

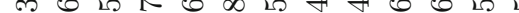

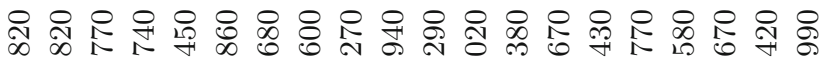
ஸ் L ○

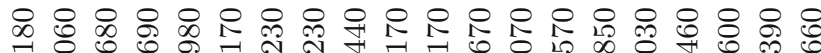

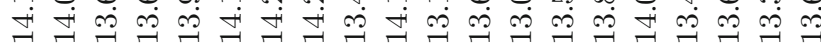
L

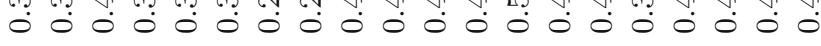

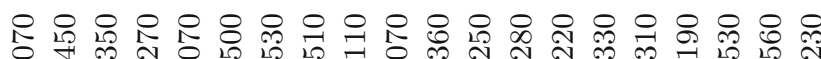

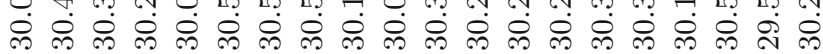

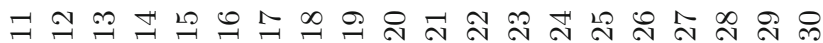

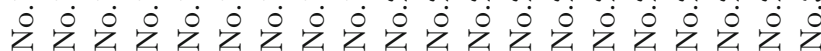

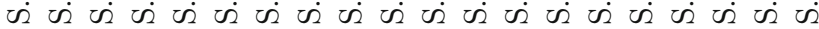

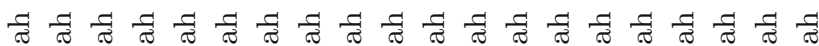

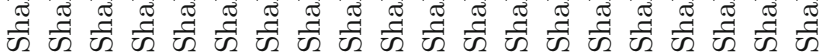

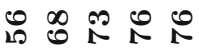

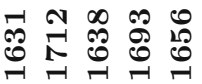

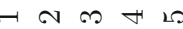

$\infty \infty \infty \infty$ $\sum \sum \sum_{i} \sum_{i}^{\infty}$

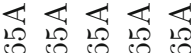

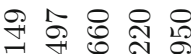
$\dot{8} \dot{8} \dot{8} \dot{8} \dot{\Omega}$

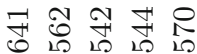
$\dot{0} \dot{0} \dot{0} \dot{0} \dot{0}$

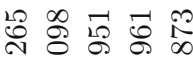
ง

\&

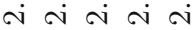

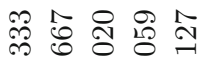
$\exists$ ㄱํ ำ ล $100 \%$

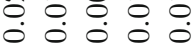
강용

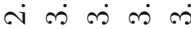

ळి రి $\circ 0000$

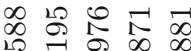
-

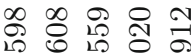

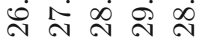
๓ $-i 00$ 유유요 0 iा म

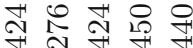
00000

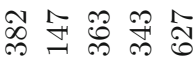
교묘

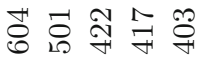
00000

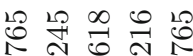
में लि ले

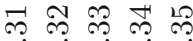

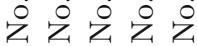

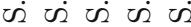
สี สี สี สี สี 䉼施 
$\underset{\infty}{\infty} \infty \underset{\infty}{\infty}$ \&ै \&

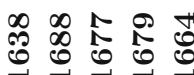

or $\infty$ o응 $\infty \infty \infty \infty$

$\sum \sum_{i} \sum_{i}$

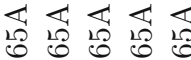

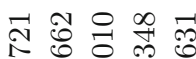
ஓं \& \& \& \&

กิ ०० 0000

索苾苾茂

$-\rightarrow-x$

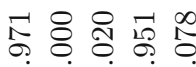

ก

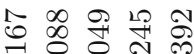

ำ ำ ำ ำ

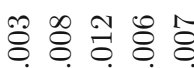

0000

ॠ लि कि

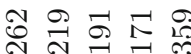

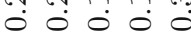
궁 2 $\ddot{0} \dot{0} \dot{0}$

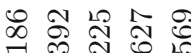
के

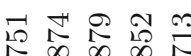
$\dot{\circ} \dot{\circ} \dot{\circ} \dot{\circ} 0$

인 ले ले ले

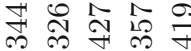

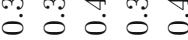

茂

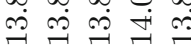

旅芷令 ○े 000

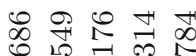
के लंमें

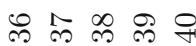
$\dot{0} \dot{0} \dot{0} \dot{0} \dot{0}$ is is is is is

สี สี สี สี สี

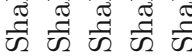

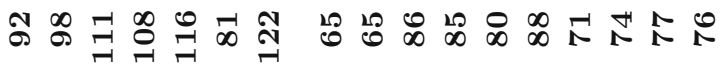

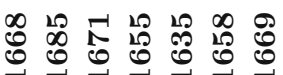

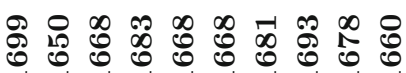

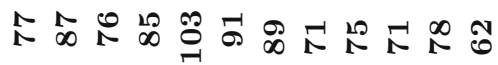

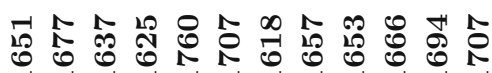
H ก M

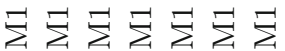

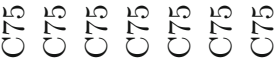

Ha n n

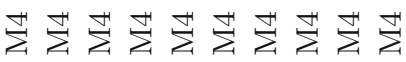

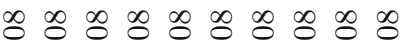
U 슨

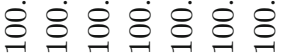

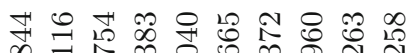

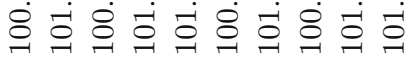

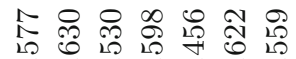
过

ฟH ᄋ 유 유 논 동 ㅇํㅇ ๘

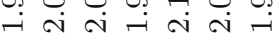

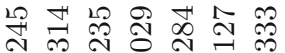
ำ ำ ำ ำ ำ

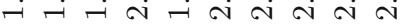

Ұ゙ 용 \&

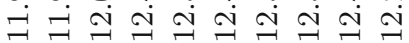

ஓ

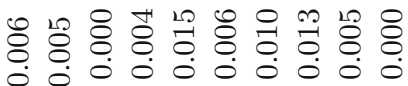

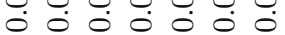
ঋ ले ले ले

귀 웍

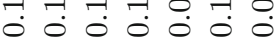

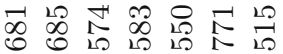
0000000

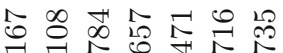
வे 윤 $-\rightarrow-r-$

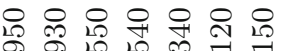

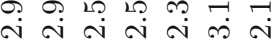

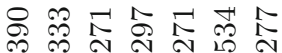

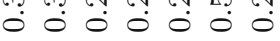

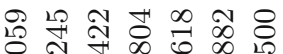

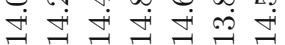

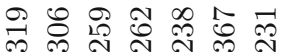
: $0 \dot{0} 0 \dot{0} 0$

苟 进

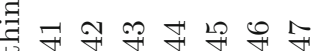
i

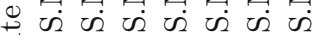

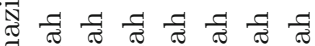

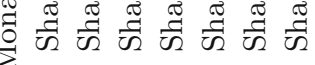

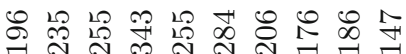

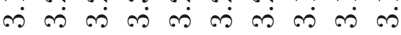

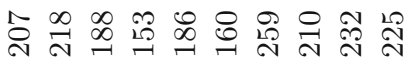
:

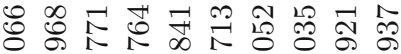

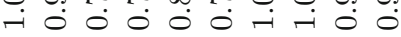

จิ సิำ

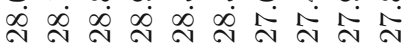

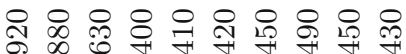
- $-\dot{-i}-\dot{-} \dot{-}-\dot{-}$

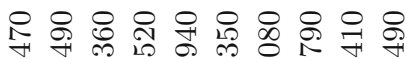
+ $\forall$ i 車

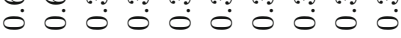
约 ற்

ᄋํㅇ

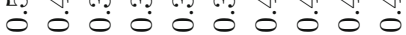

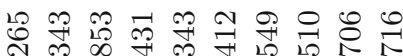

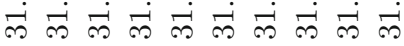

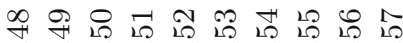

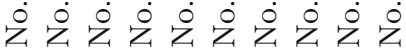

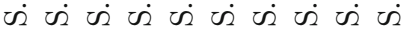
สี สี तี สี สี สี สี สี तี

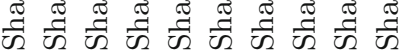

-

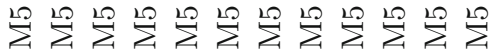
N会卡卡卡卡卡卡卡

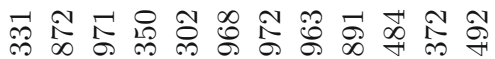

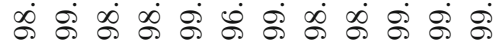

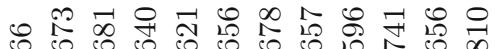

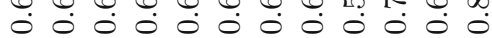

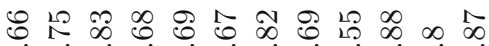
$--1--1--1$

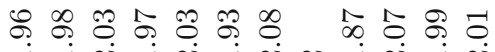

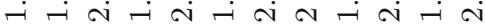

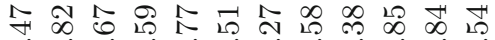

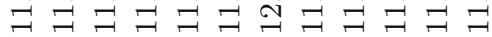

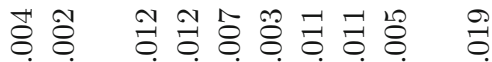
o 0 o 000000000 그 구 ๙ิ่

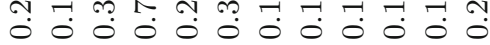
బ

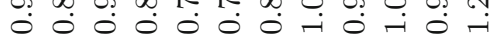
获

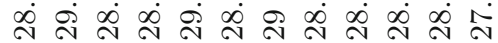

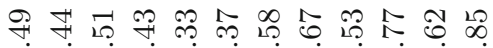

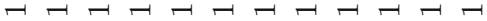
की ๖

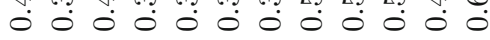

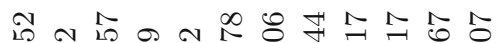

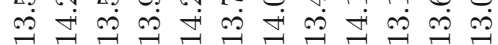

위유 000000000000

๖ Ұ வ் $\infty$ iิ

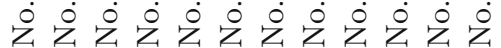

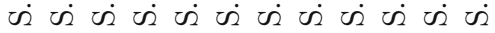

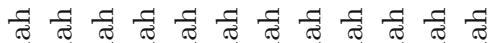

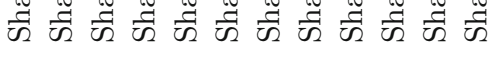




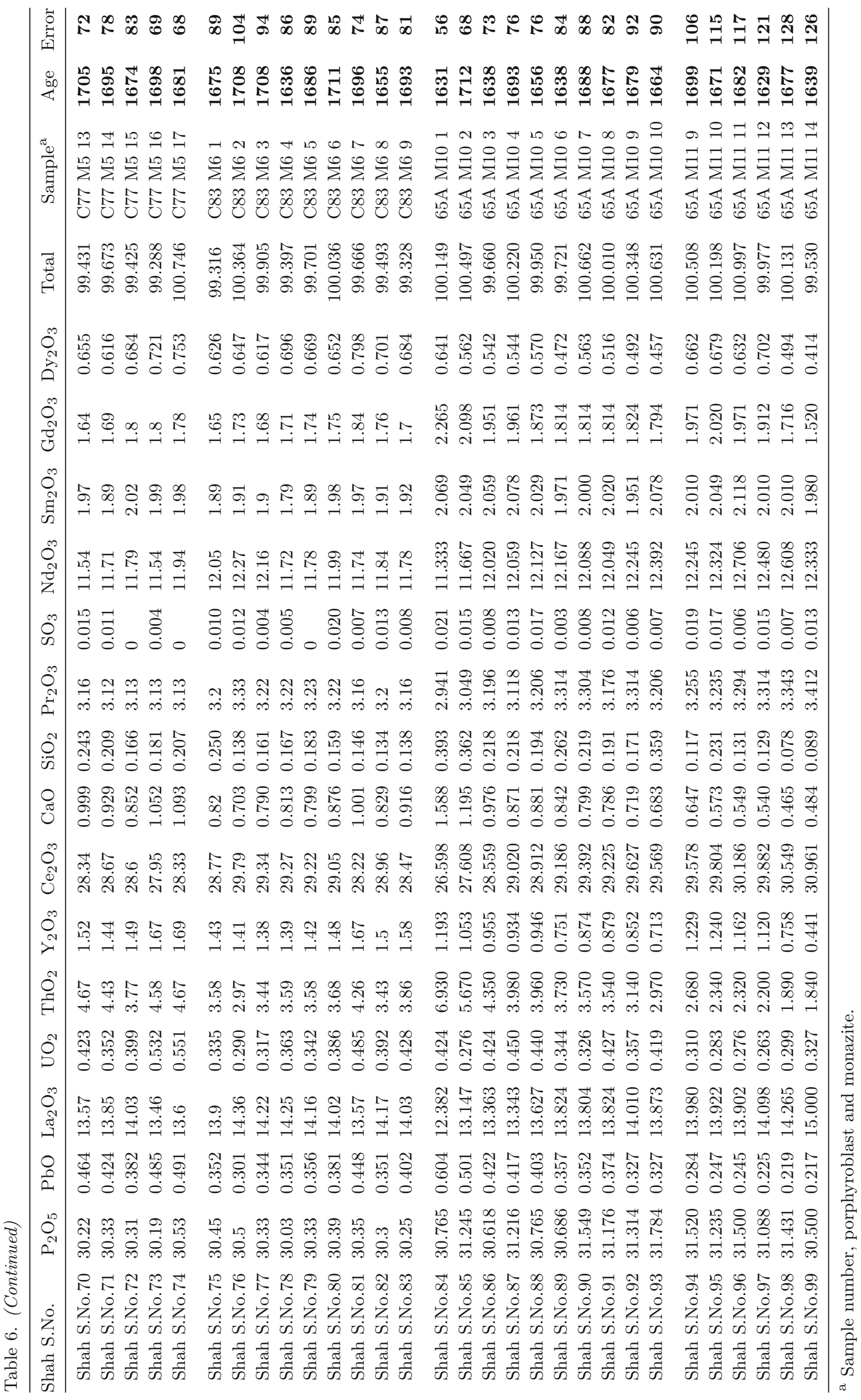




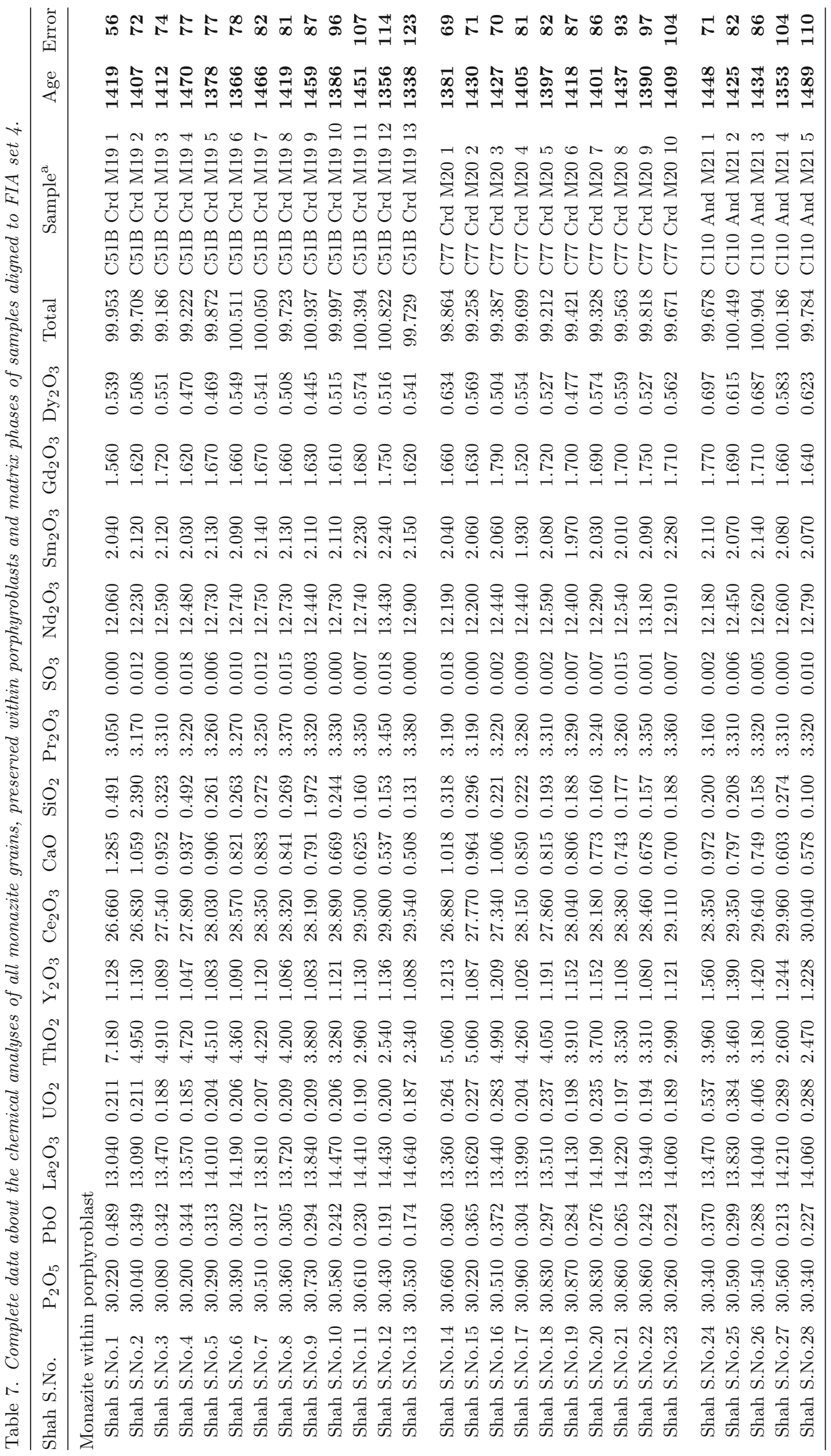




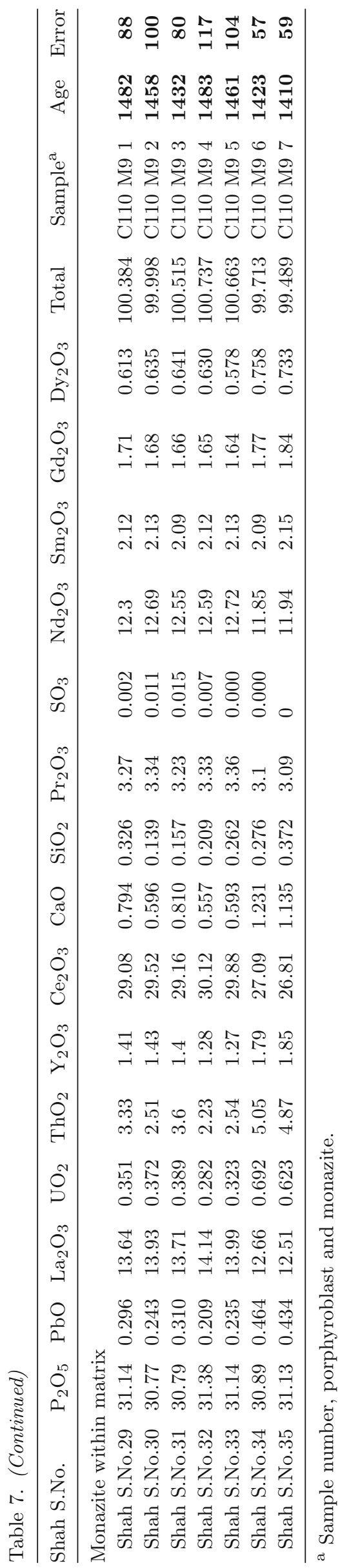

foliation gave an age of $1762 \pm 35 \mathrm{Ma}$ (figure 9). This sample preserves FIA sets 1 and 2 within staurolite porphyroblasts (figure 8). The monazite grains are not zoned (figures 10 and 11).

\subsection{Sample C84 (FIA 2 in garnet and 3 in staurolite)}

The dominant foliation in the matrix $\left(\mathrm{S}_{\mathrm{e} 1}\right)$ contains a single monazite grain that lies sub-parallel to it that has an age of $1729 \pm 23$ Ma (see tables 3 and 5).

\subsection{Sample C65A (FIA 1 in garnet and 2 plus FIA 3 in staurolite)}

Two monazite grains in the main matrix foliation $\left(\mathrm{S}_{\mathrm{ea}}\right)$ have ages $1742 \pm 29 \mathrm{Ma}$ and $1665 \pm 23 \mathrm{Ma}$ (e.g., table 3; figures 12 and 13). Both lie subparallel to $\mathrm{S}_{\mathrm{ea}}$. A monazite grain in staurolite is shown in figure 14).

\subsection{Sample C43 (FIA 1 in garnet and 2 in staurolite)}

A single monazite grain parallel to the main matrix foliation $\left(\mathrm{S}_{\mathrm{e} 1}\right)$ has an age of $1724 \pm 37 \mathrm{Ma}$ (see tables 3 and 5). This sample preserves FIA sets 1 and 2 within garnet and staurolite porphyroblasts.

\subsection{Sample C51B (FIA 3 in cordierite)}

A single monazite grain lying orthogonal to the main matrix foliation $\left(\mathrm{S}_{\mathrm{e} 1}\right)$ in this sample has an age of $1685 \pm 29 \mathrm{Ma}$ (see tables 3 and 6). This sample preserves FIA set 3 within cordierite porphyroblasts.

\subsection{Sample Cry (FIA 3 in cordierite)}

A single monazite grain lying in the youngest matrix foliation $\left(\mathrm{S}_{\mathrm{e} 3}\right)$ in this sample has an age of $1677 \pm 19 \mathrm{Ma}$ (see tables 3 and 6 ). This sample preserves FIA set 3 within cordierite porphyroblasts.

\subsection{Sample C108 (FIA 1 in garnet and 2 in staurolite)}

A single monazite grain sub-parallel to the main matrix foliation $\left(\mathrm{S}_{\mathrm{e} 1}\right)$ has an age of $1675 \pm$ $24 \mathrm{Ma}$ (see tables 3 and 6 ). This sample preserves FIA sets 1 and 2 within garnet and staurolite porphyroblasts. 
(a)

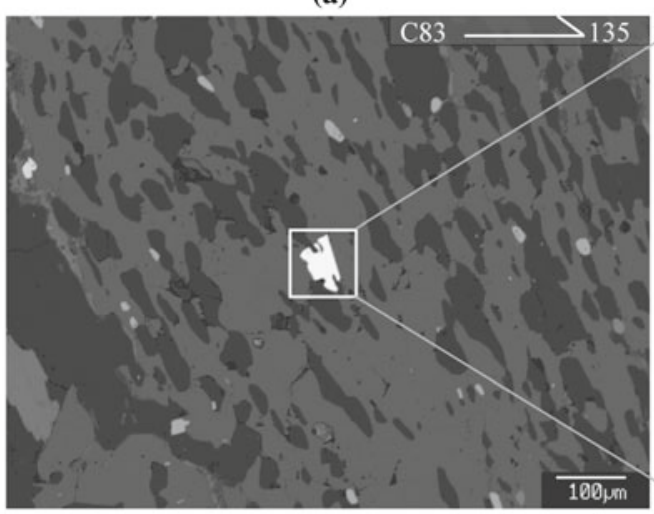

(c)

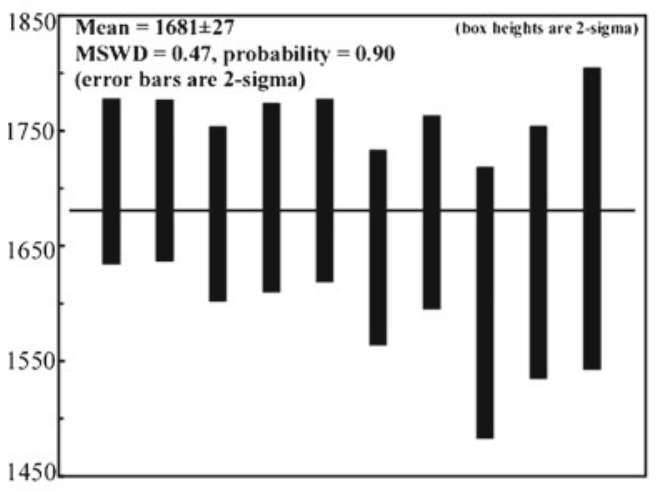

(b)

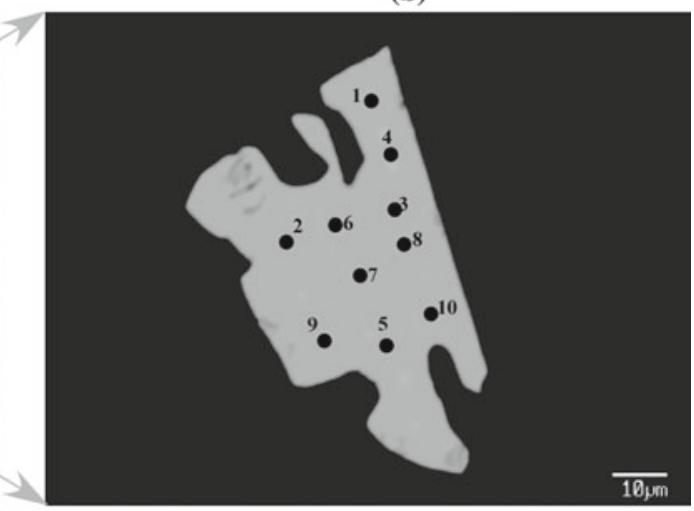

(d)

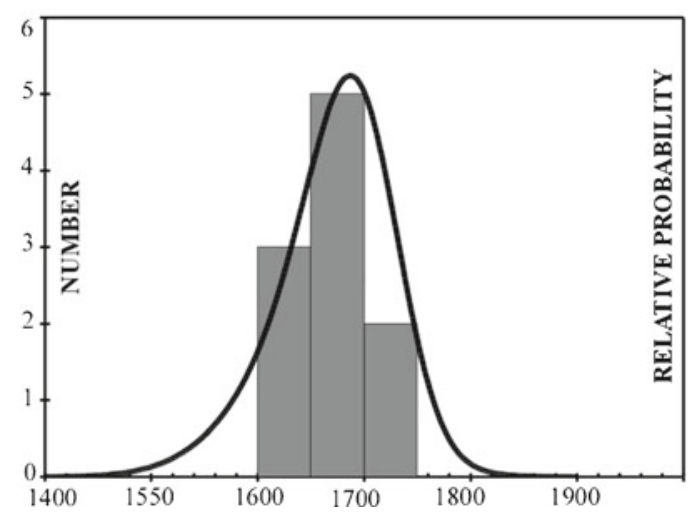

Figure 7. (a) Back scatter image shows the staurolite porphyroblast, which contains a single monazite grain lying parallel to the orientation of the foliation. A mean age of $1681 \pm 27 \mathrm{Ma}$ is dated from a total of 10 spots analyzed (Sanislav and Shah 2010). (b) Enlarged view of the monazite grain with black spots showing the location of each analysis. In (c) the weighted average age plot is shown, created by using Isoplot software (Ludwig 1998) and (d) is showing the probability density plot.

\subsection{Sample C110 (FIA 4 in andalusite)}

A single monazite grain sub-parallel to the main matrix foliation $\left(\mathrm{S}_{\mathrm{e} 1}\right)$ has an age of $1438 \pm 30 \mathrm{Ma}$ (see tables 3 and 7 ). This sample preserves FIA set 4 within andalusite porphyroblasts.

\section{Compositional mapping of monazite grains}

Samples containing monazite were compositionally mapped for $\mathrm{Th}, \mathrm{Y}, \mathrm{U}, \mathrm{Pb}$ and $\mathrm{Ce}$ using the JEOL JXA-8300 Superprobe. Most were devoid of any apparent chemical zoning (e.g., figures 10 and 11). One monazite in the matrix of sample C65A showed chemical zoning in both Th and Y (figure 13). Dating of $1742 \pm 29$ and $1668 \pm 48 \mathrm{Ma}$ suggests that this was a product of FIAs 1 and 3 (see below). Sample C75 showed a single example of a monazite with slight zoning in Th preserved within a staurolite porphyroblast (figure 11). A mean age of $1712 \pm 25 \mathrm{Ma}$ was analyzed from this grain.

\section{Interpretation and discussion}

\subsection{The ages within porphyroblast containing FIAs}

The monazite grains stored within foliations defining FIAs in garnet, staurolite (Sanislav and Shah 2010), cordierite and andalusite have recorded ages over an extended period of metamorphism. For example garnet in sample C117, preserves the oldest deformation event recorded in the area at $1756 \pm 22 \mathrm{Ma}$. The date obtained from this porphyroblast agrees with the other samples containing the same FIA sets. This is shown in sample C84, which records the same event in garnet at $1762 \pm$ $21 \mathrm{Ma}$ and fits well with its FIA. The younger grain stored within staurolite is ellipsoidal and aligned parallel to the foliation defined by the inclusion trails and should give a representative age for FIA 3 (Sanislav and Shah 2010). The $1666 \pm 26 \mathrm{Ma}$ age in garnet $(\mathrm{C} 51 \mathrm{~B})$ accords with the dates obtained from other samples bearing this FIA set (e.g., staurolite grains dated in Sanislav and Shah 2010). The two dates obtained from monazite grains preserved within pseudo-FIA in cordierite (set 3) and as 
(a)

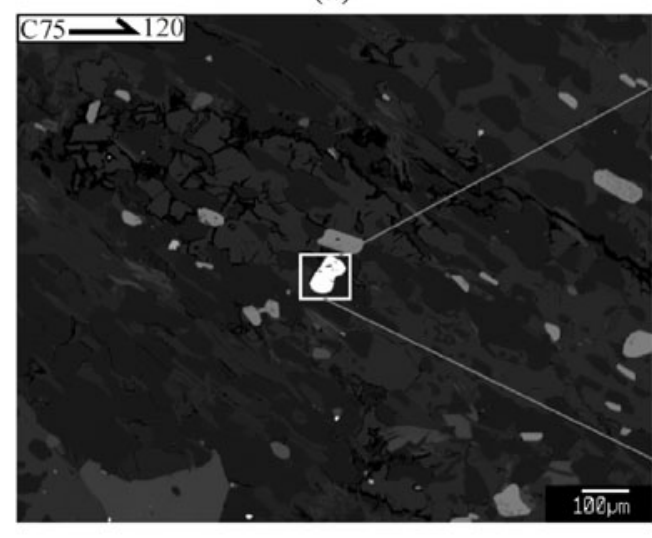

(c)

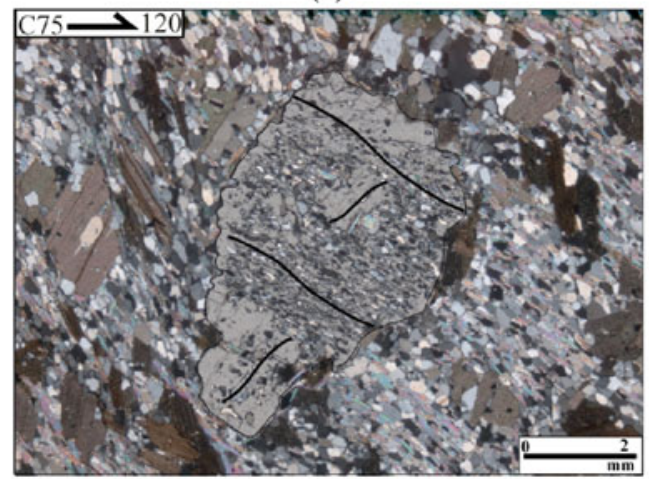

(e)

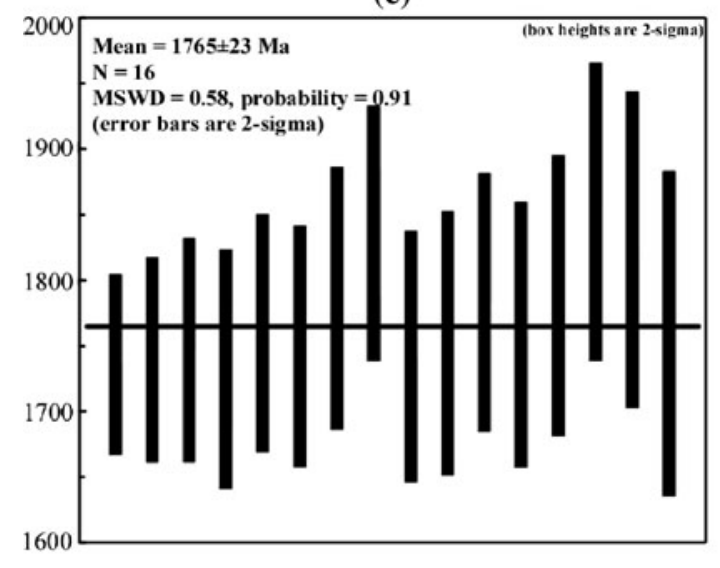

(b)

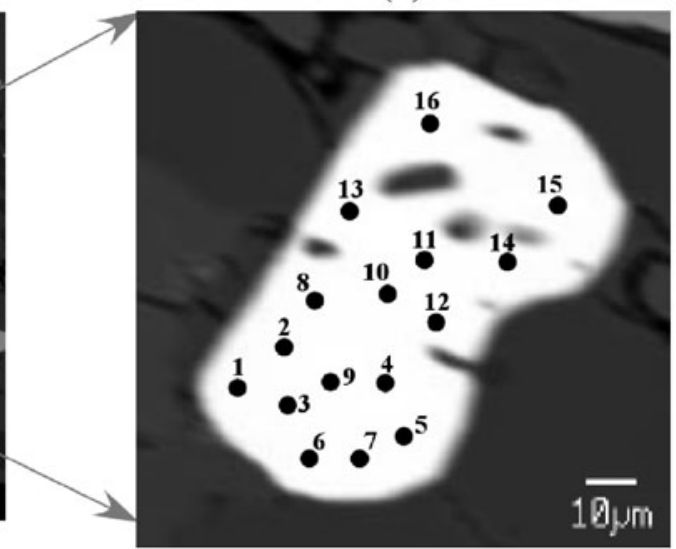

(d)

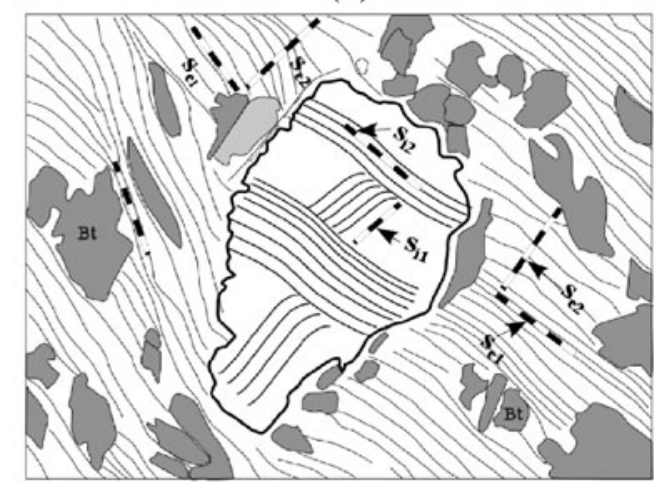

(f)

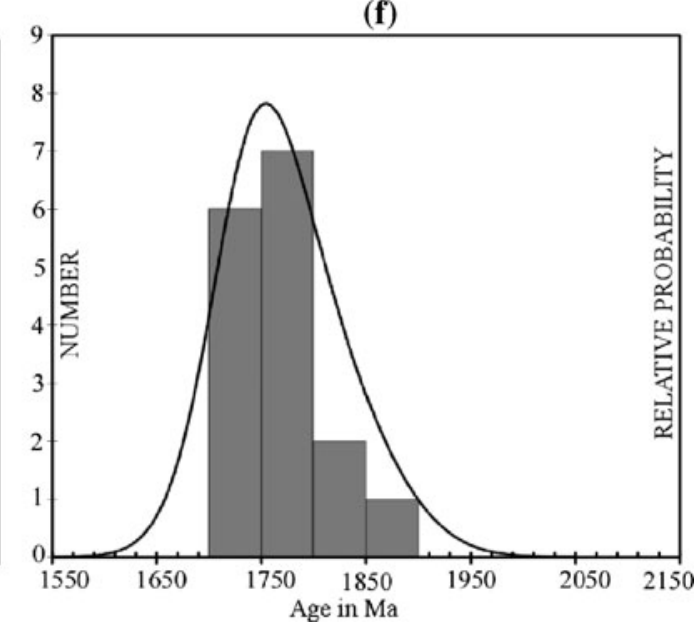

Figure 8. (a) Back scatter electron image shows a staurolite porphyroblast, which preserves a single euhedral monazite grain lying orthogonal to the orientation of the foliation. A mean age of $1765 \pm 23 \mathrm{Ma}$ is dated from a total of 16 spots analyzed (Sanislav and Shah 2010). (b) Enlarged view of the monazite grain with black spots showing the location of each analysis. X-ray images of this monazite grain are shown in this figure. (c) Orientated photomicrograph displays the larger view of the staurolite dated. Two different foliations are preserved within staurolite porphyroblast. Monazite grain was contained within a crenulation cleavage. In this sample, staurolite contains a pseudo-FIA belonging to set 1 FIA plus FIA set 2. Thin section is vertical, the light is plane-polarized and single barbed arrow indicates way up and strike. (d) Line diagram, shows the detailed features preserved. In (e) weighted average age plot is shown which is created by using Isoplot software (Ludwig 1998) and in (f) the probability density plot is shown. Se: external foliation, Si: internal foliation, Grt: garnet, St: staurolite, and Bt: Biotite.

single FIA in andalusite (set 3) in the sample C77, accord with the dates obtained from other samples for this event (table 3). The two earlier ages acquired from monazite grains within the main foliation of cordierite are relics of an older foliation that lies oblique to the main foliation defined by the 


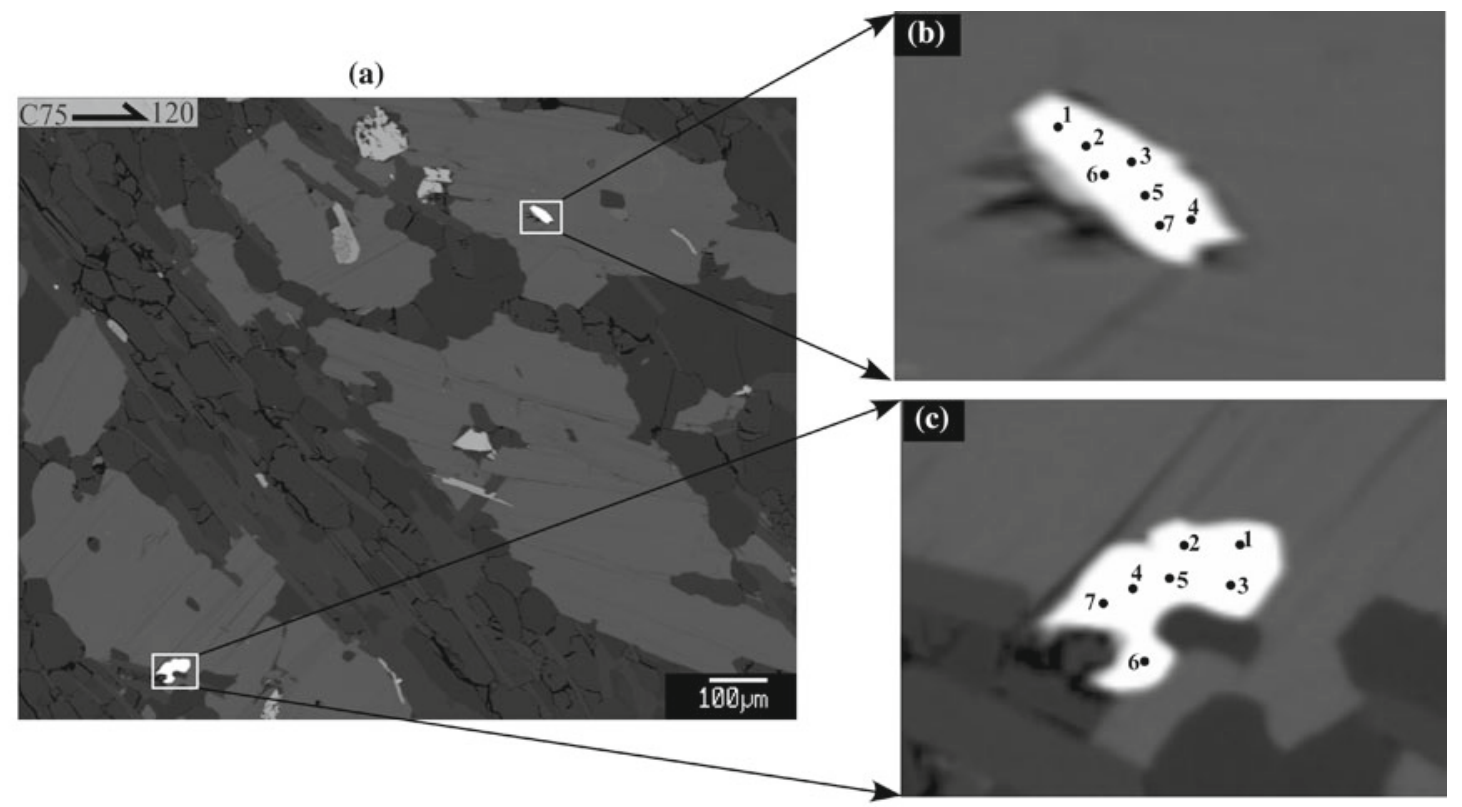

(d)

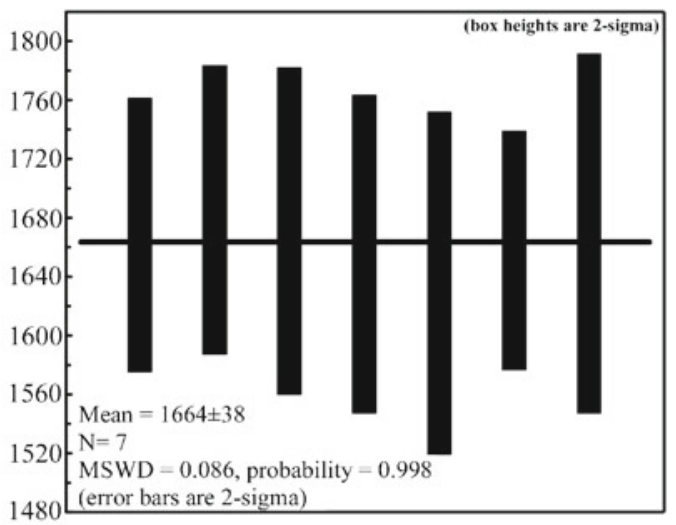

(f)

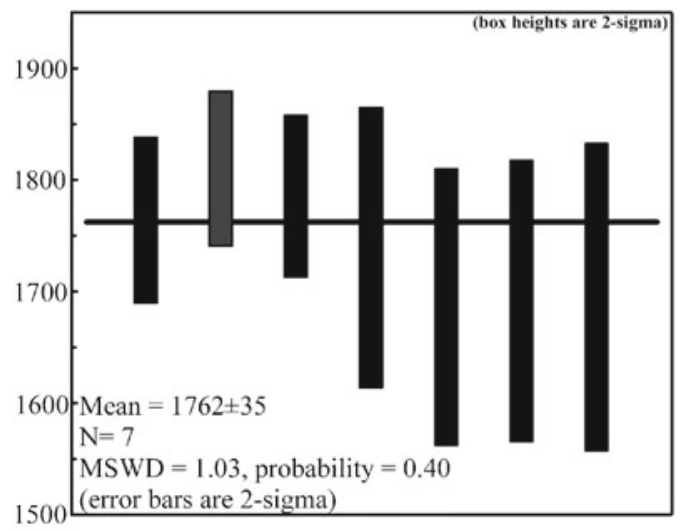

(e)

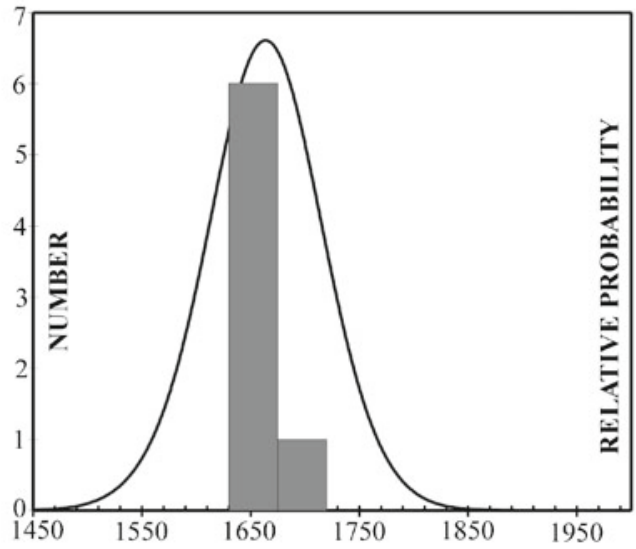

(g)

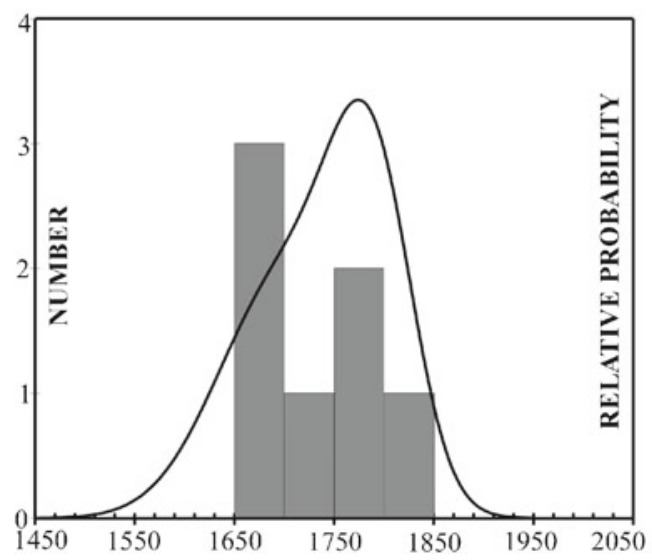

Figure 9. (a) Back scatter electron image shows two monazite grains preserved within matrix foliation of sample C75. (b) Enlarged view of a monazite grain with black spots showing the location of each analysis. This euhedral grain is preserved within the main matrix foliation and is located parallel to its orientation. A mean age of $1664 \pm 38 \mathrm{Ma}$ is dated from a total of seven spots analyzed. (c) Enlarged view of a monazite grain with black spots showing the location of each analysis. This grain is oriented orthogonal to the orientation of the main matrix foliation. A mean age of $1762 \pm 35 \mathrm{Ma}$ is dated from a total of seven spots analyzed. Thin section is vertical, single barbed arrow indicates way up and strike. In (d and f) weighted average age plots are shown, created by using Isoplot software (Ludwig 1998) and in (e and g) the probability density plots are shown. 
(a)

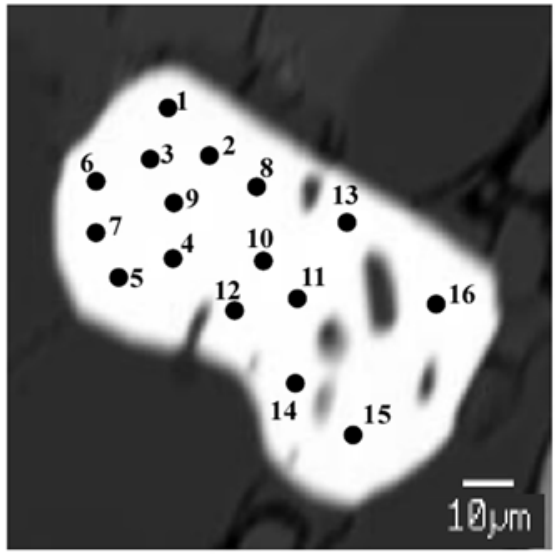

(d)

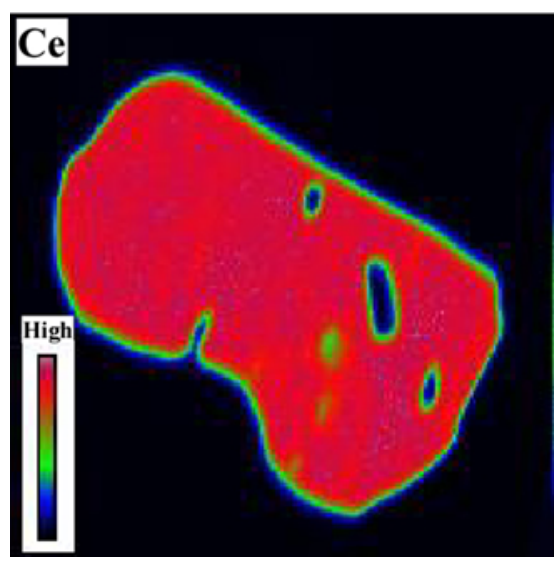

(b)

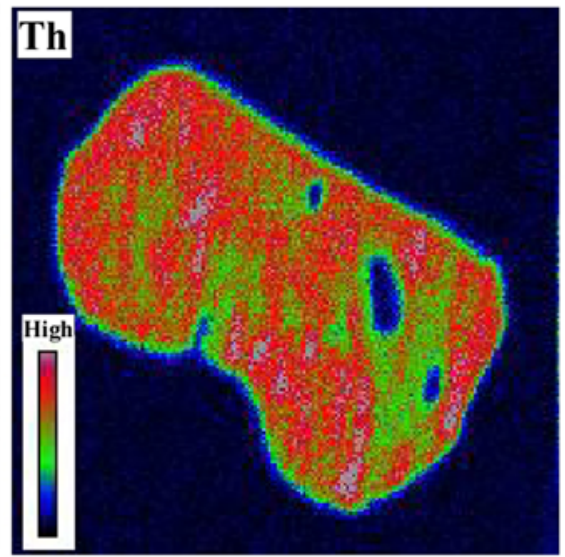

(e)

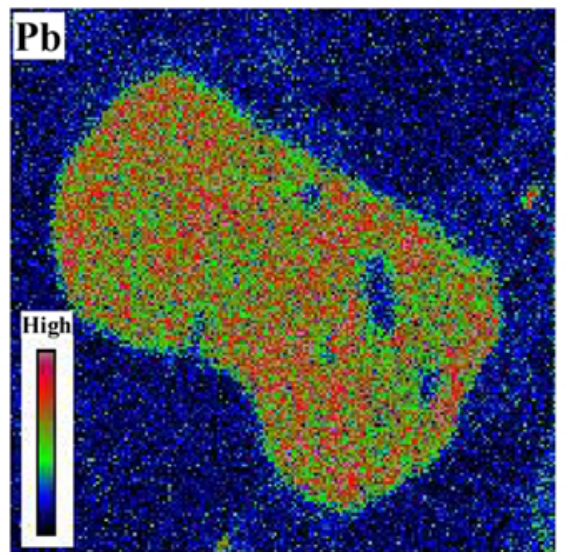

(c)

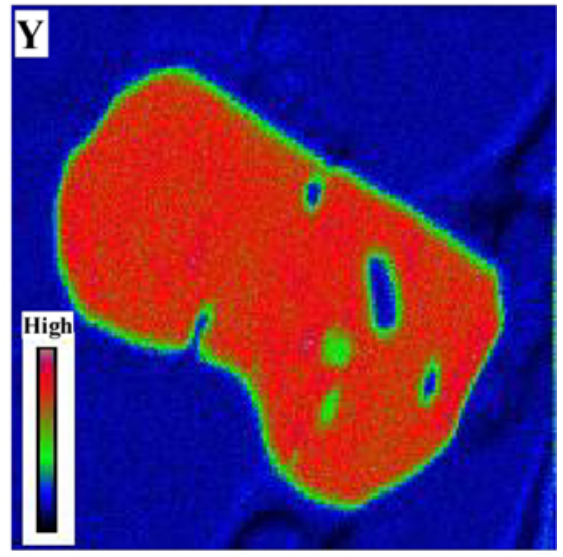

(f)

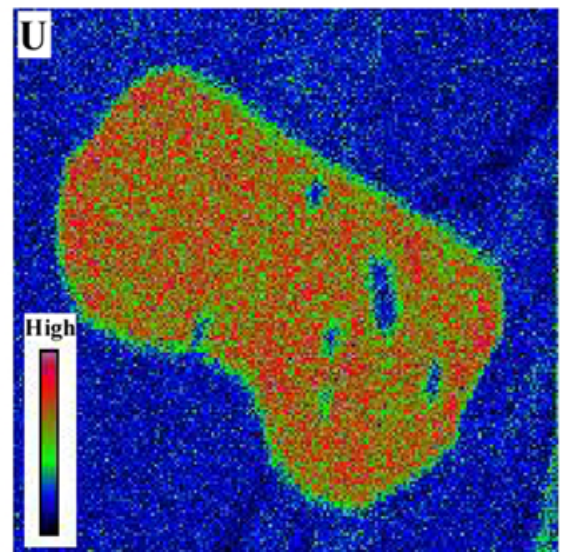

Figure 10. (a) Back scatter oriented electron image of a monazite grain preserved within the foliation of porphyroblast that contains the inclusion trails of FIA set 1 in sample (C75). The location of each analysis is shown by black spots. In (b) through (f), X-ray maps of $\mathrm{Th}, \mathrm{Y}, \mathrm{Ce}, \mathrm{Pb}$ and $\mathrm{U}$ are shown. Chemical zoning in $\mathrm{Th}$ and $\mathrm{Pb}$ is crudely present.

inclusion trails. Their dates are compatible with the ages obtained from FIA sets 1 and 2, preserved within other samples. The date acquired from two monazites in cordierite (C51B) accords with the dates obtained from other samples for FIA set 4 (see table 3). An older age within this sample from one monazite is consistent with an earlier foliation aligned to FIA set 1 and represents its relics. The age recorded in sample $\mathrm{C} 110$ is consistent with the youngest FIA set observed.

\subsection{Combining the age data within FIA sets}

Monazite grains are common within staurolite (Sanislav and Shah 2010), cordierite and andalusite porphyroblasts but rare in garnet. Of the 11 samples investigated, five contained inclusion trails defining FIA set 1; six monazite grains were identified and 93 analyses completed defining an age of $1760.5 \pm 9.7 \mathrm{Ma}$ (table 3; figure 15a and b). Five samples contained inclusion trails defining FIA set 2; eight monazite grains were identified and
136 analyses completed defining an age of $1719.7 \pm$ 6.4 Ma (table 3; figure 15c and d). Five samples contained inclusion trails defining FIA set 3; five monazite grains were identified and 56 analyses completed defining an age of $1674 \pm 11 \mathrm{Ma}$ (table 3 ; figure 15e and f). Three samples contained inclusion trails defining FIA set 4; three monazite grains were identified and 28 analyses completed defining an age of $1415 \pm 16 \mathrm{Ma}$ (table 3 ; figure $15 \mathrm{~g}$ and $\mathrm{h}$ ). These ages $(1760.5 \pm 9.7,1719.7 \pm 6.4,1674 \pm 11$ and $1415 \pm 16 \mathrm{Ma})$, respectively, confirm the FIA $1,2,3,4$ succession established using core/rim criteria plus the previously recognized (Tweto 1987; Nyman et al. 1994; Karlstrom et al. 1997) separation of orogenesis into two distinct periods 250 million years apart (Shah 2010).

\subsection{The significance of FIAs for determining monazite ages}

Texturally controlled dating of monazite inclusions has recently been used by many petrologists 

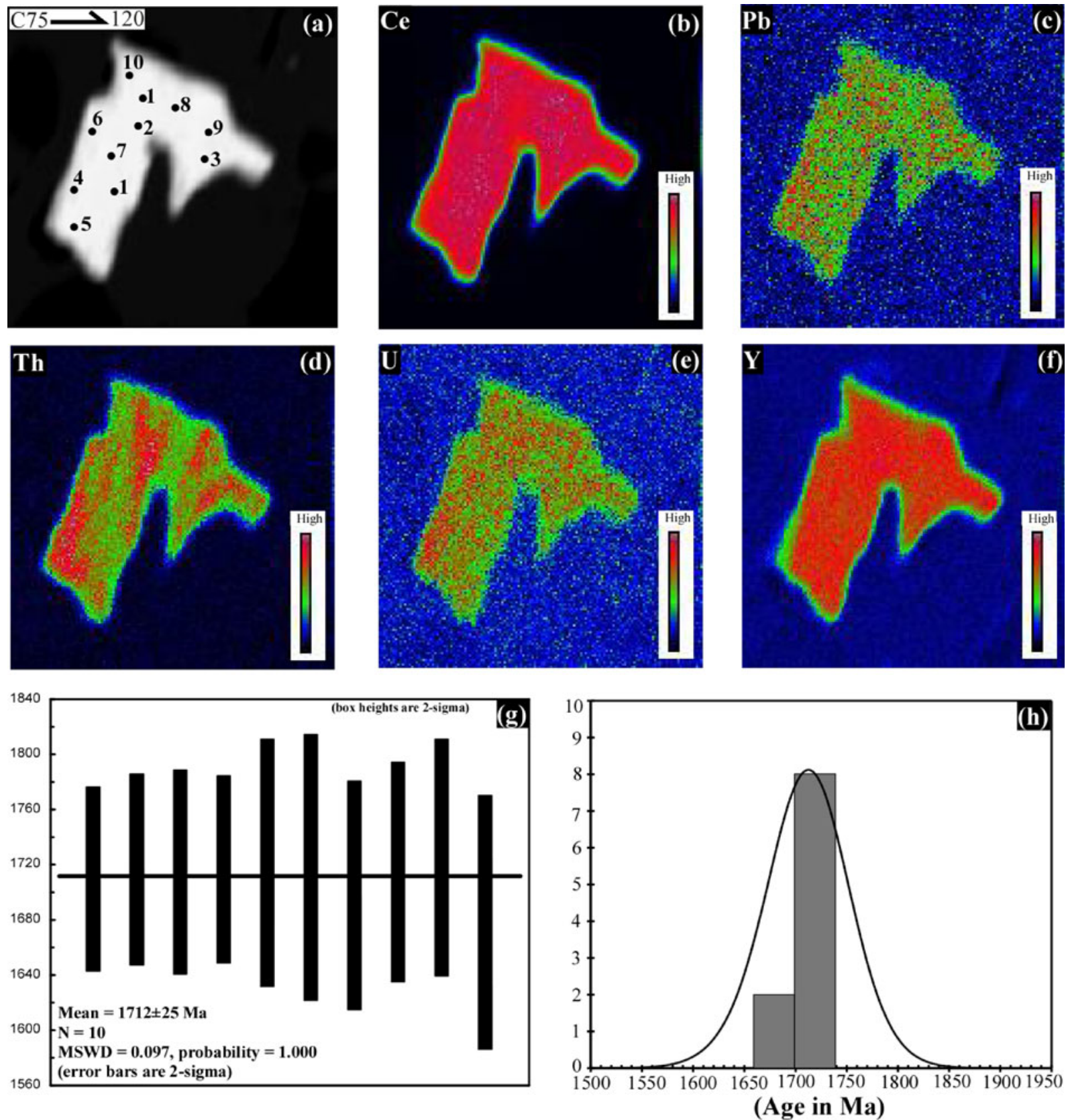

Figure 11. (a) Back scatter oriented electron image of a monazite grain preserved within the foliation of porphyroblast that contains the inclusion trails of FIA set 2, in sample (C75). The location of each analysis is shown by black spots. Single barbed arrow indicates way up and strike. In (b) through (f) X-ray maps of Ce, $\mathrm{Pb}$, Th, U and Y are shown. Chemical zoning in Th is crudely present. A single mean age of $1712 \pm 25 \mathrm{Ma}$ is preserved within this monazite, which is coeval with the ages obtained from the other samples for the regional deformation that produced this FIA set. In (g) the weighted average age plot of eight spots is shown which is created by using Isoplot software (Ludwig 1998) and in (h) the probability density plot is shown.

around the world to date foliation ages (Williams et al. 1999; Shaw et al. 2001; Dahl et al. 2005). A range of ages will always be present in the matrix due to the potential for the preservation of monazite grains within the strain shadows of successively grown porphyroblasts and this is exemplified by table 3. Depending on the timing of porphyroblast growth, a similar range can be preserved from the influence of younger events. The most critical phase in using an absolute microstructural dating method is to accurately identify monazite grains within a particular textural and structural setting. FIA provide such a setting and offer a robust opportunity to extract in situ information from individual monazite grains preserved within an independently determined relative timeframe.

The accord between FIA set and age recorded herein is remarkable (table 3). Only one sample 

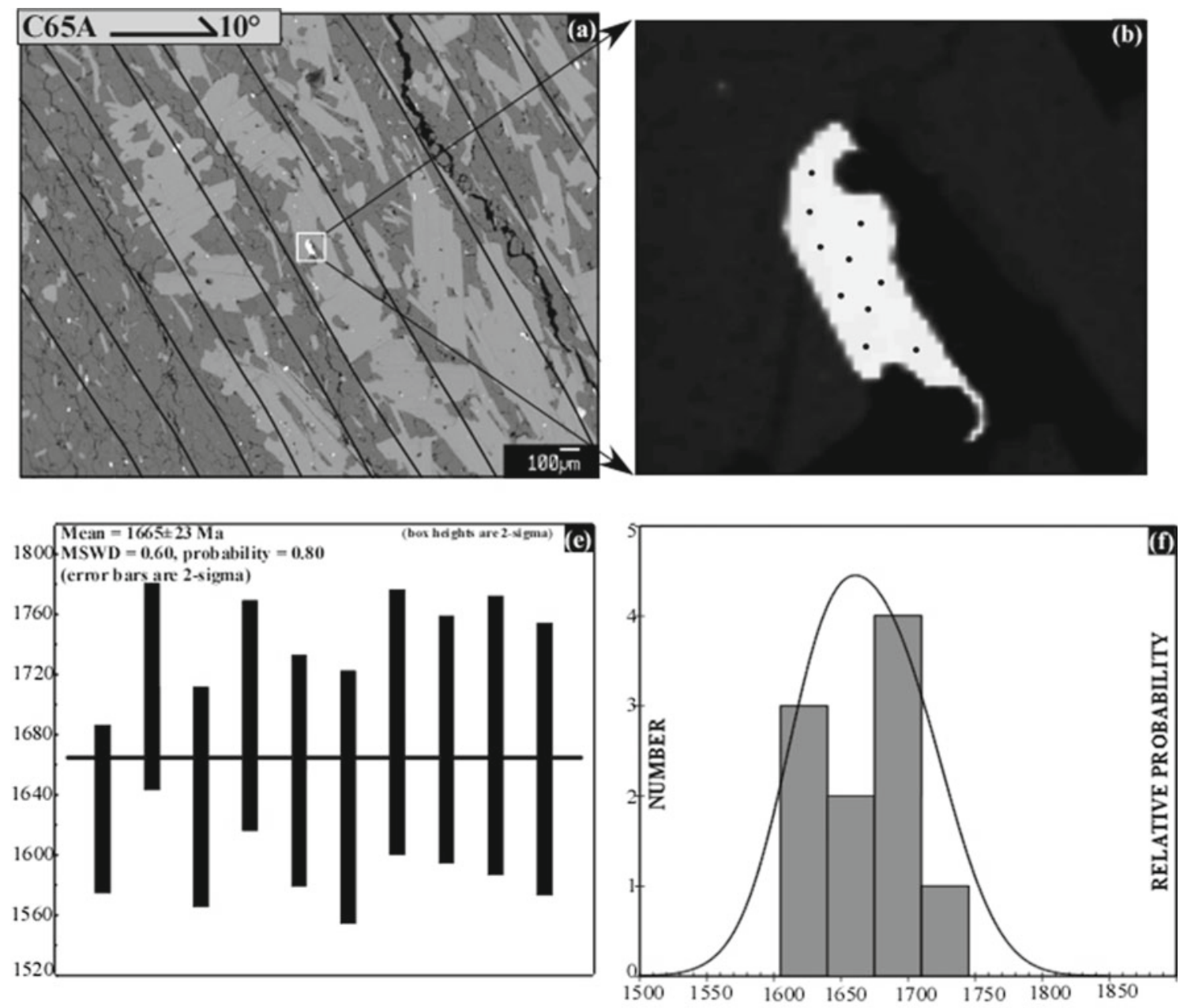

Figure 12. (a) Shows a back scatter in which a monazite grain is preserved within a matrix foliation which is lying parallel to the orientation of the foliation. A mean age of $1665 \pm 23 \mathrm{Ma}$ is dated from a total of 10 spots analyzed. (b) Enlarged view of the monazite grain with black spots showing the location of each analysis. Single barbed arrow indicates way up and strike. In (e) the weighted average age plot of 18 spots is shown, created by using Isoplot software (Ludwig 1998). (f) shows a probability density plot.

(C77) contains 'anomalous' older ages which can be attributed to the earlier events as just mentioned. The recognition of pseudo-FIAs and FIAs provided tight control over what FIA sets were preserved in each sample. Without this level of control on the distribution of FIAs, the $\sim 100$ million year range in ages obtained (not including the far younger $\sim 1400$ Ma ages) would have been attributed to noise. Instead it accords perfectly with the independently obtained succession of FIA sets!

\subsection{The ages within matrix}

The older monazite grain $(1762 \pm 35 \mathrm{Ma})$ in sample C75, accords with the dates acquired for FIA set 1 (table 3 ). The younger matrix age obtained is coeval with dates acquired for FIA set 3 suggesting that the matrix was reused or reactivated during the development of this FIA set. The single matrix age in sample (C84), accords with the date for FIA set 2 (table 3) and is interpreted to represent a relic of an earlier-formed foliation. Similar ages were obtained within the sample C65A, which are consistent FIA sets 1 and 3 (table 3) and are interpreted to represent relics of earlier-formed foliations preserved within the strain shadows of porphyroblast. In sample $\mathrm{C} 43$, the matrix age obtained $(1724 \pm 37 \mathrm{Ma})$ accords with the dates acquired for FIA set 2 (see table 3 ), which suggests reactivation of the matrix during these events. This monazite grain was parallel to the main matrix foliation $\left(\mathrm{S}_{\mathrm{e} 1}\right)$. Another relic age $(1723 \pm 34 \mathrm{Ma})$ was acquired in the sample $\mathrm{C} 83$, and is consistent with FIA set 2 rather than for FIA set 3 . This suggests that this grain was not deformed and recrystallized during the development of FIA 3 prior to staurolite growth. Some crystallographic orientations of grains relative to a developing strain field can make 
(a)
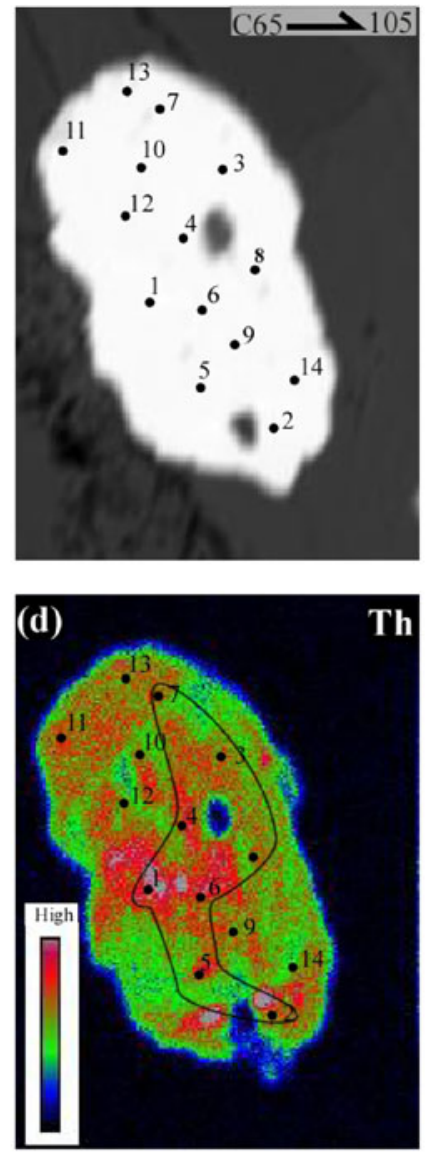

(b)
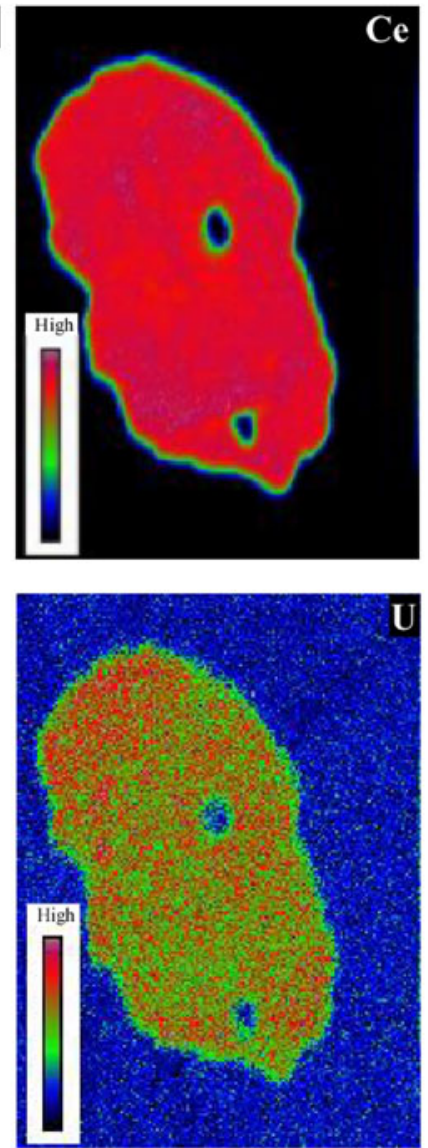

(c)

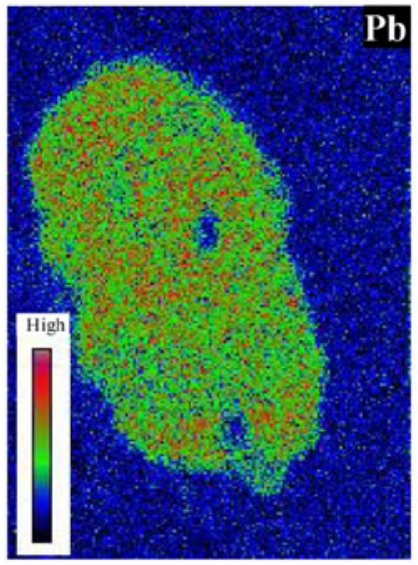

(f)

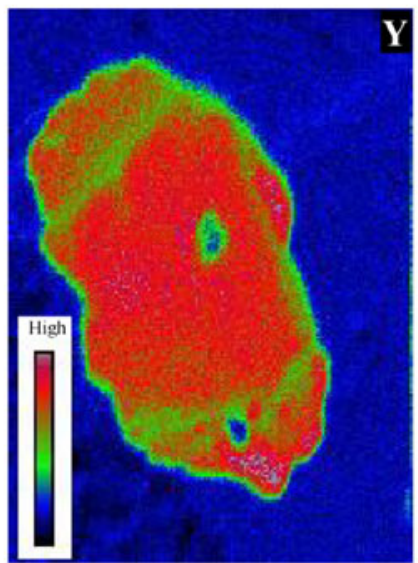

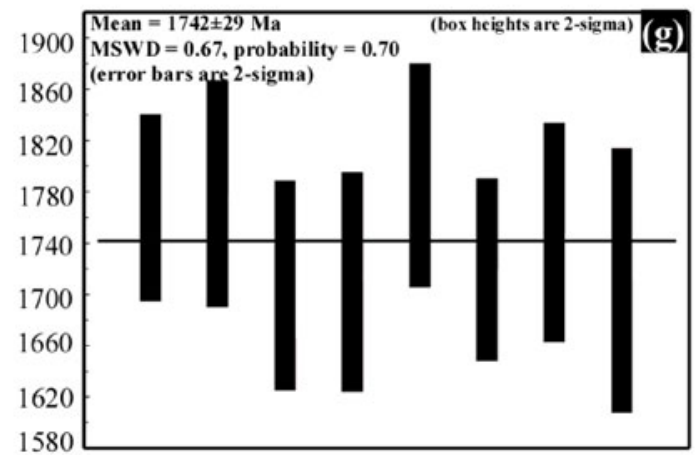
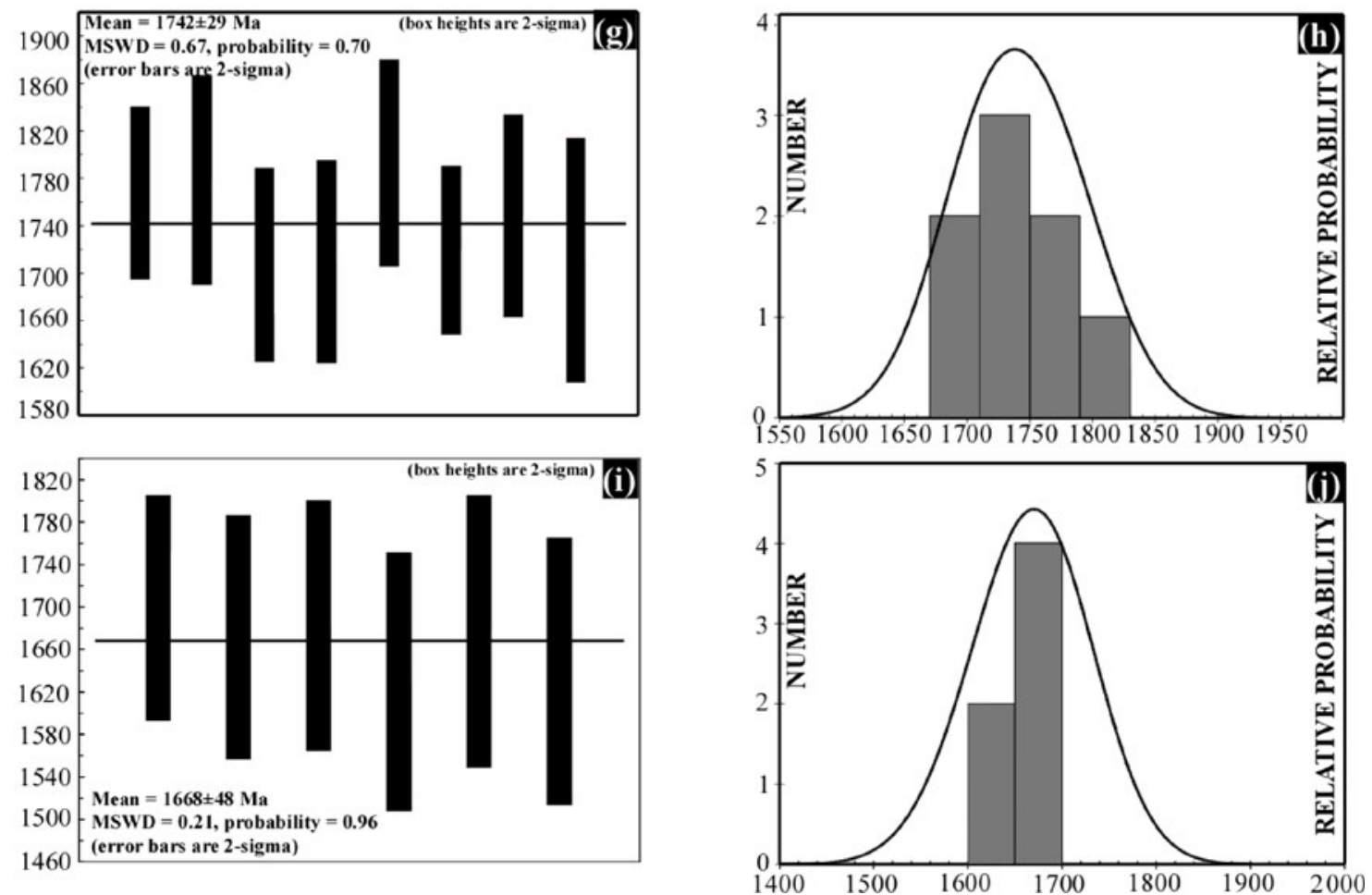

Figure 13. (a) Back scatter oriented electron image of a monazite grain preserved within the matrix of the sample (C65A), which shows the location of each analysis. (b) through (f), shows the X-ray maps of Ce, $\mathrm{Pb}, \mathrm{Th}, \mathrm{U}$ and $\mathrm{Y}$ respectively. Age zoning in the chemical contents of $\mathrm{Th}$ and $\mathrm{Y}$ is present, which offer two different age domains. A mean age of $1742 \pm$ $29 \mathrm{Ma}$ is preserved within high Th domains (polygonal area). The relatively low Th regions contain a mean age of 1668 $\pm 48 \mathrm{Ma}$. Thin section is vertical, single barbed arrow indicates way up and strike. ( $\mathrm{g}$ and $\mathbf{i}$ ) shows weighted average age plots, created by using Isoplot software (Ludwig 1998) and in (h and $\mathbf{j}$ ) the probability density plot is shown. 

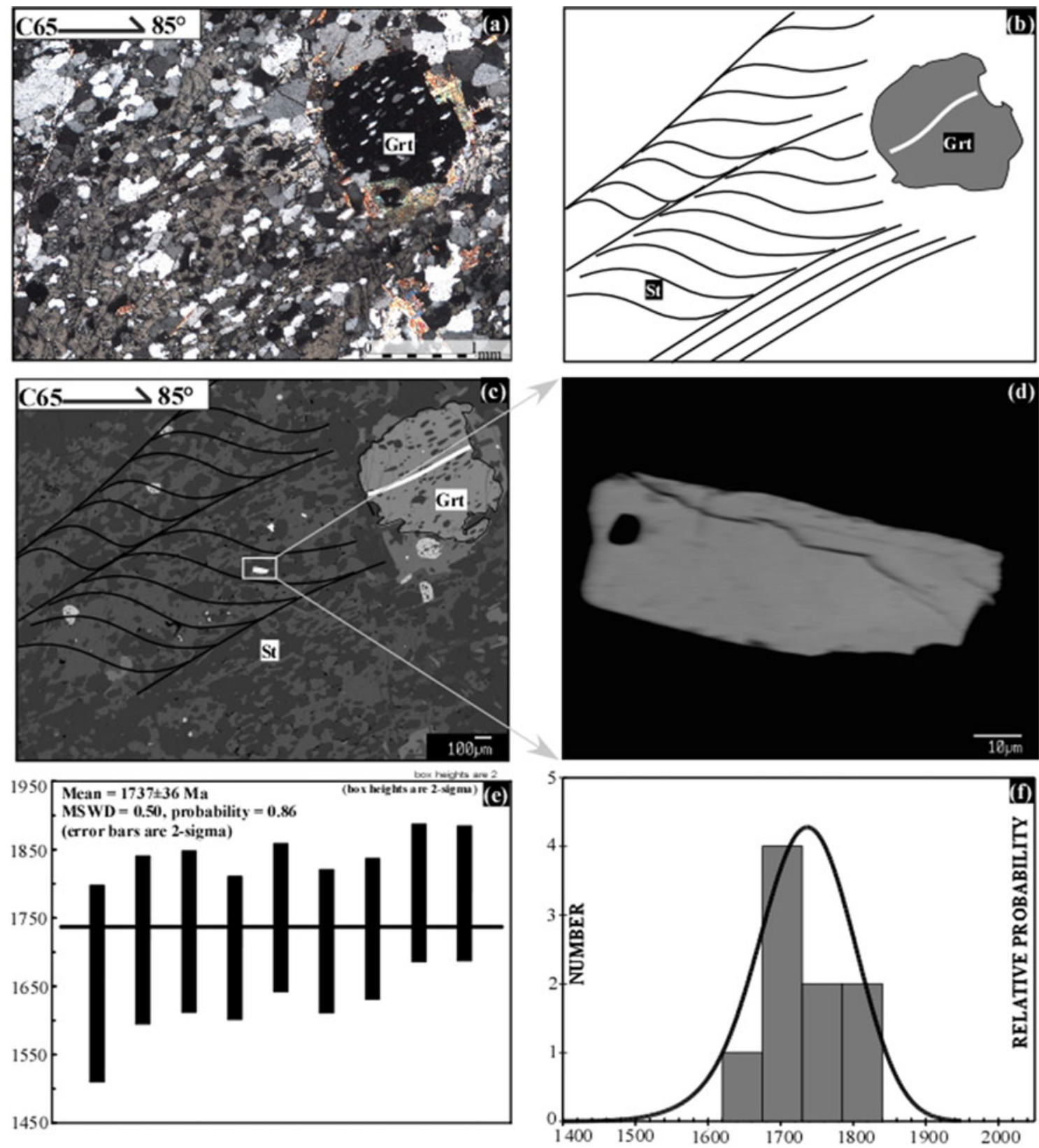

Figure 14. (a and b) Photomicrograph and accompanying line diagram from sample C65A (cross polarized light) which preserves a crenulated and a crenulation cleavage within staurolite porphyroblast. Garnet also contains a foliation which is different from those contained within the staurolite. Thin section is vertical, the light is cross-polarized and the single barbed arrow indicates way up and strike. (b) Back scatter image shows the staurolite porphyroblast preserving a single euhedral monazite grain within a crenulated cleavage of the same thin section. A mean age of $1737 \pm 36 \mathrm{Ma}$ is dated from a total of nine spots analyzed (Sanislav and Shah 2010). (c) Enlarged view of the monazite. In (e) weighted average age plot of 18 spots is shown which is created by using Isoplot software (Ludwig 1998) and (f) shows the probability density plot.

a particular mineral phase very competent and hard to deform (e.g., Mancktelow 1981). This grain could reflect such a phenomenon. In samples C51B, $\mathrm{C} 77$ and $\mathrm{C} 108$, the acquired ages accord with the dates obtained for FIA set 3 suggesting these monazites grew at this time and were preserved through modification of the matrix by subsequent deformation events. A younger age was preserved within a monazite of sample C110, which is consistent with ages for FIA set 4 . This was obtained in the foliations preserved within the andalusite porphyroblast, which are very similar to and continuous with the matrix.

\subsection{Assessing the spread of the age data from matrix relative to that for the FIA succession}

Monazite grains are common within the matrix and randomly distributed. They are generally preserved 

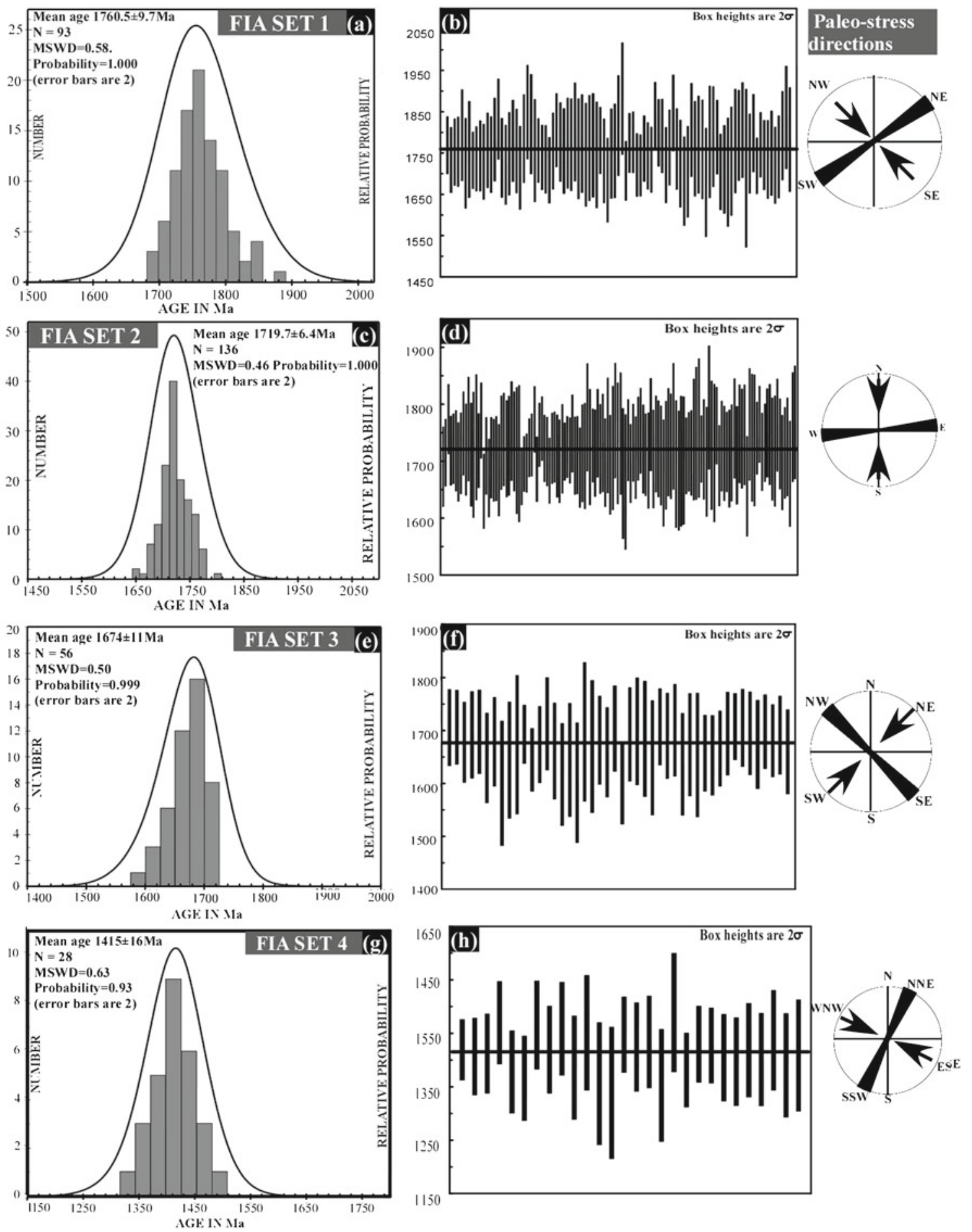

Figure 15. Probability density and weighted average age plots ( $\mathbf{a}-\mathbf{h})$ for all samples in which monazite grains were dated within matrix. These plots were created in Isoplot software (Ludwig 1998). Complete chemical data is shown in tables $4-7$.

within muscovite and biotite grains (e.g., figures 9 and 12). A total of nine samples out of 30 investigated contained monazite crystals in the matrix. Two samples each contain a monazite grain, from which a total of 14 analyses were completed defining an age of $1749 \pm 23 \mathrm{Ma}$ (table 3; figure 16a and b). Four samples contained four monazite grains from which 28 analyses were obtained defining an age of $1726 \pm 17 \mathrm{Ma}$ (table 3; figure 16c and d). Six samples contained six monazite grains from which 59 analyses were completed defining an age of $1674 \pm 11 \mathrm{Ma}$ (table 3; figure 16e and f). One sample contained a single monazite grain from which seven analyses were completed defining 

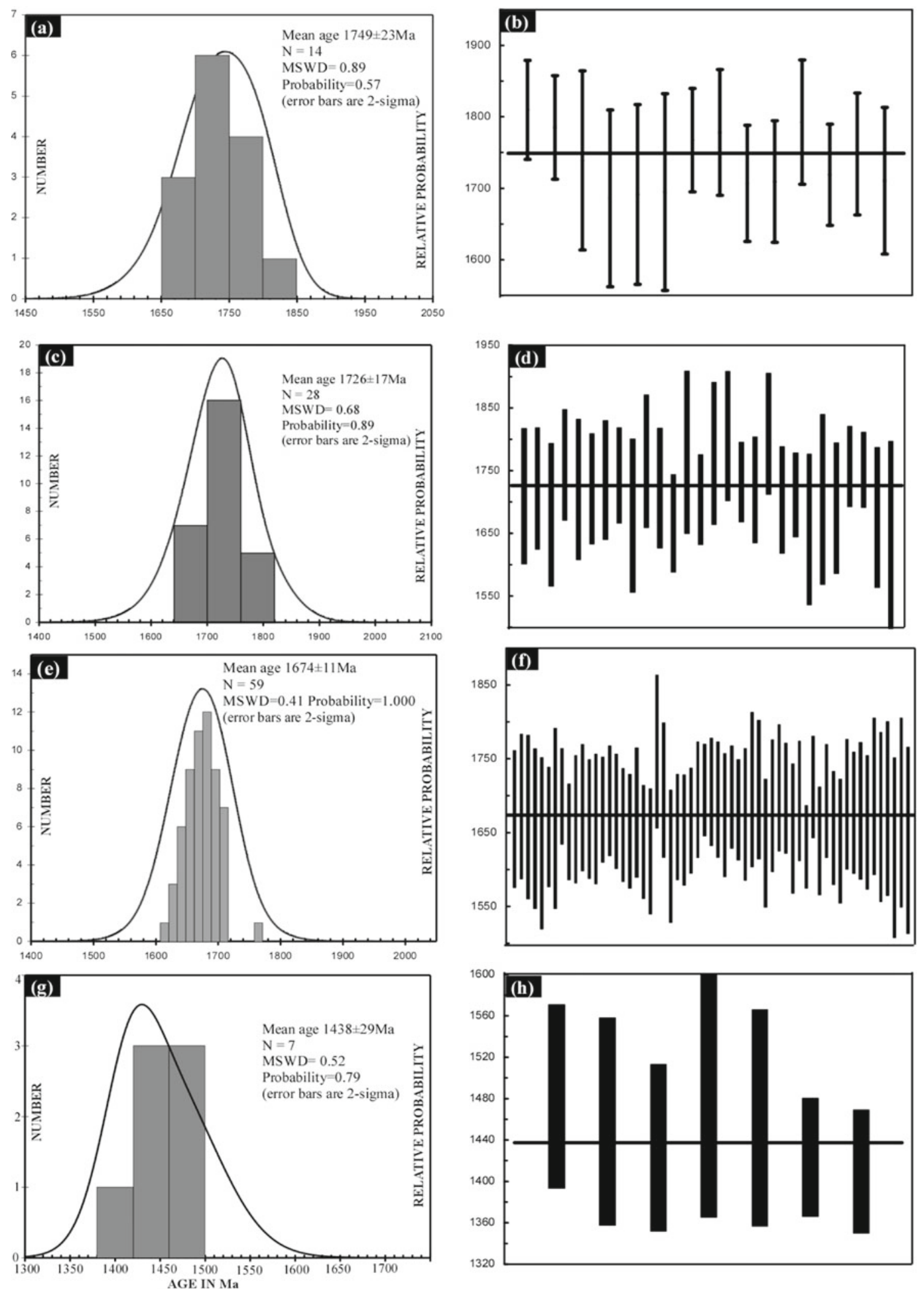

Figure 16. Probability density and weighted average age plots $(\mathbf{a}-\mathbf{h})$ for all samples in which monazite grains were dated within porphyroblasts. These plots were created in Isoplot software (Ludwig 1998). Complete chemical data is shown in tables 4-7. 
(a)

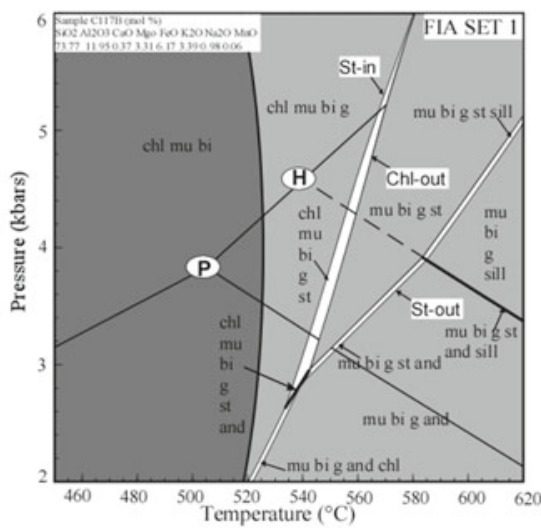

(c)

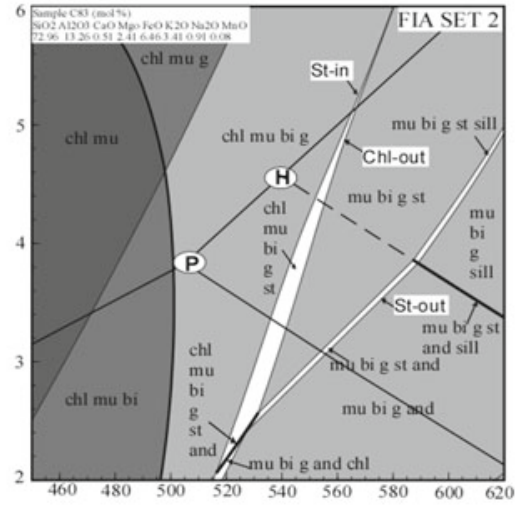

(e)

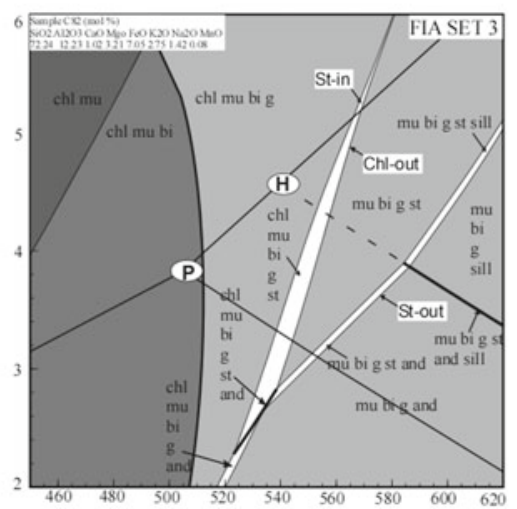

(g)

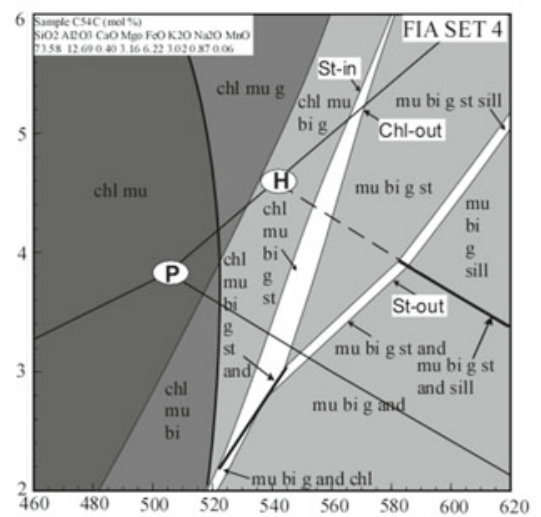

(b)

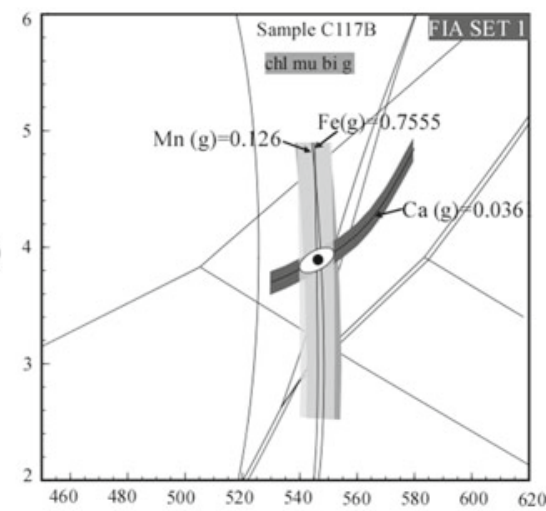

(d)

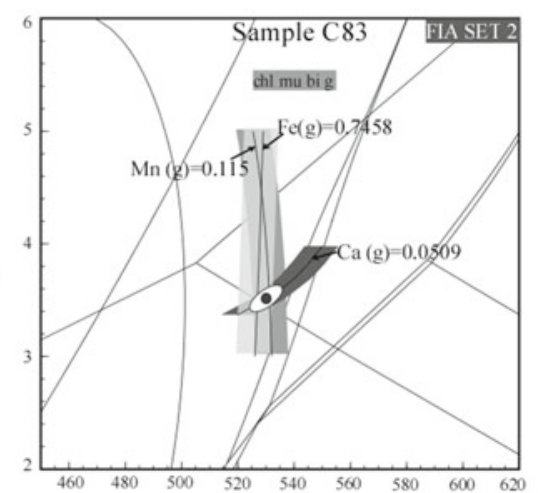

(f)

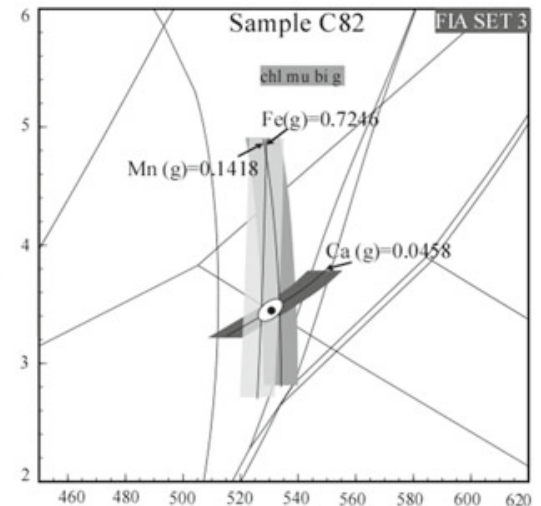

(h)

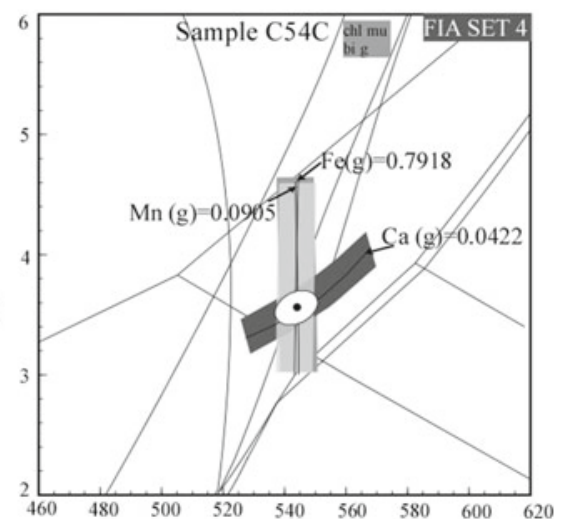

Figure 17. (a, c, e and f) P-T pseudosections calculated in the MnNCKFMASH system based on the bulk XRF composition for the samples $\mathrm{C} 117 \mathrm{~B}, \mathrm{C} 83, \mathrm{C} 82$ and $\mathrm{C} 54 \mathrm{C}$, respectively. It shows the mineral stability fields with dark toned areas representing higher variance value. The bulk composition is displayed on the upper left corner of the diagrams. (b, $\mathbf{d}, \mathbf{f}$ and h) Garnet core isopleths of $\left(\mathrm{X}_{\mathrm{Mn}}, \mathrm{X}_{\mathrm{Ca}}\right.$ and $\left.\mathrm{X}_{\mathrm{Fe}}\right)$ in which the compositional contours corresponding to the real composition (microprobe) of garnet core along with their 2-sigma errors indicated as gray-toned think lines (Shah 2010). 
an age of $1438 \pm 29 \mathrm{Ma}$ (table 3 ; figure $16 \mathrm{~g}$ and h). These ages accord to some degree with dates obtained from the porphyroblasts preserving FIA sets $1,2,3$ and 4 and clearly reflect those events in spite of the fact that there is no real control on the significance.

\subsection{The porphyroblast ages versus matrix ages}

In all the samples that were dated foliations defined by inclusion trails in porphyroblasts are truncated by matrix foliations except in sample C110. Therefore, monazite ages in the matrix have no relevance to the dating of FIAs. In most samples, monazite grains in the matrix foliation gave the same or younger ages than those within the porphyroblasts. Ages range from $1749 \pm 23$ to $1674 \pm$ 11 Ma (table 3 ) with one sample preserving a monazite with an approximate FIA 1 age of $1762 \mathrm{Ma}$ and another containing a relic from a foliation within the matrix that predated porphyroblast growth. The younger ages were always a product of reuse or reactivation of old foliations (e.g., Bell et al. 2003) or the development of new ones. Consequently, only the ages obtained from monazite grains preserved within porphyroblasts where an FIA control on the significance of that age were used to time deformation and metamorphism (figure 15). However, as mentioned above, it is apparent that most, if not all, of the ages associated with the succession of FIA development are preserved within the matrix. Yet an approach that involves dating monazite grains within the matrix can only ever provide an average age that does not distinguish when deformation commenced or when porphyroblast growth ceased.

\subsection{Role of deformation and its significance for porphyroblast growth}

Nucleation of any mineral phase requires that $\mathrm{P}-\mathrm{T}$ and bulk composition should be appropriate for that phase to grow. However, deformation is also known to play a vital role in formation of different minerals, particularly porphyroblastic phases (e.g., Bell 1986; Williams 1994; Cihan et al. 2006) through its control on sites for the access of nutrients needed for nucleation and growth (Spiess and Bell 1996). The FIA controlled monazite dating described herein reveals $\sim 90$ million years of continuous deformation/metamorphism followed by $\sim 250$ million years of quiescence before orogenesis recommenced for $\sim 20$ million years with little or no change in PT conditions (Shah 2010). What kept this region at similar crustal levels during the 250 million years of quiescence?
The PT conditions and the bulk composition were clearly suitable for the growth of porphyroblasts during the $\sim 250$ Ma between the development of FIAs 3 and 4 . Yet no porphyroblastic phases grew during this time and there is no microstructural evidence for any foliations developing. The latter fact is confirmed by dating of monazite grains within the matrix. They reflect the FIA succession and provide no evidence for any deformation between at least 1665 and 1438 Ma. It is now well established that deformation and concurrent metamorphism form cleavage seams by dissolution as well as provide a large range of components essential for the nucleation and growth of porphyroblasts (Bell and Cuff 1989; Spiess and Bell 1996). Deformation provides sites for nucleation and growth, and a means of overcoming the energy barrier for nucleation, in the form of the energy removal from, for example, crenulation hinges (Bell 1986). The lack of porphyroblast growth for this extended $\sim 250$ million year period can be attributed to the lack of crenulation development (Bell et al. 2003). When deformation recommenced around $\sim 1415 \mathrm{Ma}$, porphyroblasts also began to grow again forming FIA set 4 inclusion trails within garnet, staurolite, andalusite and cordierite porphyroblasts strongly supporting the role of crenulation deformation in porphyroblast growth (e.g., Bell 1986; Cihan et al. 2006).

\subsection{Deformation and metamorphism}

The three stages of folding and two stages of metamorphism reported previously from this region were determined from matrix foliation relationship. A much longer history of deformation and metamorphism is preserved by the porphyroblasts. The preservation of four FIA trends with changing directions of shortening from (NE-SW to E$\mathrm{W}$ to SE-NW to NNE-SSW), which range in age from $1760.5 \pm 9.7$ to $1415 \pm 16$ Ma has considerable implications for tectonics of this region. The first regional folding episode initiated during FIA set 1 at $1760.5 \pm 9.7 \mathrm{Ma}$ and trended NESW and approximately coincides with the regional trend of the Cheyenne belt. This is regarded as the suture zone along which the rocks of Colorado and Wyoming province accreted about 1790-1650 Ma ago (Sims et al. 2003). Pressure and temperature at this time was about $540^{\circ}-550^{\circ} \mathrm{C}$ and $3.8-4.0 \mathrm{kbars}$, as proposed by the garnet isopleth geothermobarometry. Intersections of $\mathrm{Ca}, \mathrm{Mg}$, and $\mathrm{Fe}$ isopleths in garnet core, which preserved FIA set 1 , indicate that these rocks never got above 4 kbars during the Colorado Orogeny (figure 17a and b).

During the formation of FIA set 2 (centred around $1719.7 \pm 6.4 \mathrm{Ma}$ ), the pressure and temperature changed slightly to $3.40-3.65 \mathrm{kbar}$ and 
$525^{\circ}-537^{\circ} \mathrm{C}$ (figure $17 \mathrm{c}$ and d). F2 regional folds were formed during this stage. Foliation evidence from this period or orogeny is rarely preserved as crenulations in the matrix, due to the effects of rotation and reactivation in the many subsequent deformations. Trondhjemite dikes, which now have a sill like character, were emplaced at $\sim 1726 \pm$ $15 \mathrm{Ma}$ (Selverstone et al. 1997). Intrusion forming $\mathrm{W}-\mathrm{E}$ trending dikes could occur along the $\mathrm{W}-\mathrm{E}$ trending vertical foliation that generated this FIA set during gravitational collapse stages of orogenesis when this vertical foliation would have created a plane of weakness that failed (e.g., Bell and Newman 2006). Subsequent reactivation of the compositional layering would have progressively rotated most of them into sub-parallelism with the bedding and disguised any crosscutting relics of the dikes along which they intruded.

FIA set 3 also developed during the Colorado Orogeny (figure 17e and f). The SE-NW trend of this FIA set was created by NE-SW shortening. Previously formed folds were refolded and a new F3, generation were created. The pressuretemperature conditions indicated by garnet isopleth conditions for this period were 3.3-3.6 kbar and $525^{\circ}-535^{\circ} \mathrm{C}$. More staurolite porphyroblasts also grew at this time. In particular, it marks the first appearance of andalusite and cordierite porphyroblasts. Some staurolite porphyroblasts containing FIA set 3 have been partially replaced by andalusite or cordierite suggesting a decrease in pressure accompanied their development. Absolute dating of monazite grains enclosed within the inclusions of these four porphyroblastic phases provide an age of $1674 \pm 11 \mathrm{Ma}$ for this period of FIA development which appears to end the Colorado Orogeny. These rocks remained undisturbed for about 250 Ma.

Monazite grains enclosed within the foliations of andalusite and cordierite porphyroblasts containing FIA set 4 give an age of $1420 \pm 14 \mathrm{Ma}$ for this period of orogenesis. The tight intersection of $\mathrm{Ca}, \mathrm{Mn}$ and $\mathrm{Fe}$ isopleths in garnet cores indicates that the pressure conditions during this period of orogenesis were similar to those observed at the end of the Colorado Orogeny (figure $17 \mathrm{~g}$ and $\mathrm{h}$ ). Large-scale heating event associated with granite emplacement and some deformation at this time is regionally known as the Berthoud Orogeny (Sims et al. 2003). FIA set 4 trends NNE-SSW and resulted from NNW-SSE directed shortening. Garnet, staurolite, cordierite and andalusite also grew during this period of orogenesis. Slightly higher temperatures were recorded during this period of orogenesis than previously. Some andalusite and cordierite were formed by replacing staurolite porphyroblasts but most grew as completely new grains. After this period of orogenesis, these rocks were retrogressed, presumably during exhumation. This is revealed by pseudomorphs after staurolite, garnet, cordierite and andalusite (Shah 2010).

\subsection{Regional tectonic implications of Colorado and Berthoud Orogenies}

The metasediments exposed in and around the Big Thompson region of Colorado represent mature sediments deposited in a fore-arc (Condie and Martel 1983) or back-arc setting (Reed et al. 1987). Detrital zircon ages suggest a maximum age of $1758 \pm 26$ Ma for deposition of the Big Thompson sequence (Selverstone et al. 2000). Previous researchers (e.g., Selverstone et al. 1997; Chamberlain 1998; Shaw et al. 2001; Williams et al. 1999) suggested protracted metamorphism and deformation associated with the $\sim 1700$ Ma orogeny and local effects due to the $\sim 1400 \mathrm{Ma}$ orogeny. The evidence presented here for deformation and metamorphism around $1758.8 \pm 9 \mathrm{Ma}$ suggests orogenesis commenced around the time of sedimentation. This correlates with the beginning of contractional deformation along the Cheyenne belt, during which time the Colorado province was accreted onto the Archean Wyoming province (Chamberlain 1998). Orogenesis was essentially continuous for about $\sim 100 \mathrm{Ma}$ and then ceased. FIA data reveal that deformation during $1420 \pm 14$ Ma Berthoud Orogeny was pervasive, with well-preserved foliations that are continuous with the matrix foliation. However, not a single monazite grain of Berthoud age was found within garnet or staurolite porphyroblasts that could be associated with this event. They were found only in andalusite and cordierite suggesting a slight change in T, $\mathrm{P}$ conditions from those forming staurolite was required for further growth of this phase.

\section{Acknowledgements}

The authors would like to thank Prof. Tim Bell for his critical comments. Special thanks to Dr Mike Rubenach for help with monazite dating and critical discussions. Funding for this work was provided by the James Cook University.

\section{References}

Ali A 2010 The tectono-metamorphic evolution of the Balcooma metamorphic group, north-eastern Australia: A multidisciplinary approach; J. Metamorph. Geol. 28 $397-422$.

Bell T H 1986 Foliation development and refraction in metamorphic rocks: Reaction of earlier foliations and 
decrenulation due to shifting patterns of deformation partitioning; J. Metamorph. Geol. 4 421-444.

Bell T H and Cuff C 1989 Dissolution, solution transfer, diffusion versus fluid flow and volume loss during deformation/metamorphism; J. Metamorph. Geol. 7 425-448.

Bell T H and Chen A 2002 The development of spiralshaped inclusion trails during multiple metamorphism and folding; J. Metamorph. Geol. 20 397-412.

Bell T H and Welch P W 2002 Prolonged Acadian Orogenesis: Revelations from FIA controlled monazite dating of foliations in porphyroblasts and matrix American; J. Sci. 302 549-581.

Bell T H and Newman R L 2006 Appalachian Orogenesis: The role of repeated gravitational collapse; In: Styles of Continental Contraction (eds) Mazzoli S and Butler R W H; Geol. Soc. Am. Spec. Paper 414 95-118.

Bell T H and Bruce M D 2007 Progressive deformation partitioning and deformation history: Evidence from millipede structures; J. Struct. Geol. 29 18-35.

Bell T H, Forde A and Wang J 1995 A new indicator of movement direction during orogenesis: Measurement technique and application to the Alps; Terra Nova. 7 500-508.

Bell T H, Hickey K A and Upton G J G 1998 Distinguishing and correlating multiple phases of metamorphism across a multiply deformed region using the axes of spiral, staircase and sigmoidally curved inclusion trails in garnet; J. Metamorph. Geol. 16 767-794.

Bell T H, Ham A P and Hickey K A 2003 Early formed regional antiforms and synforms that fold younger matrix schistosities: Their effect on sites of mineral growth; Tectonophys. 367 253-278.

Bell T H, Ham A P and Kim H S 2004 Partitioning of deformation along an orogen and its effects on porphyroblast growth during orogenesis; J. Struct. Geol. $\mathbf{2 6}$ 825-845.

Bell T H, Ham A P, Hayward N and Hickey KA 2005 On the development of gneiss domes; Australian J. Earth Sci. 52 183-204.

Braddock W A and Cole J C 1979 Precambrian structural relations metamorphic grade, and intrusive rocks along the northeast flank of the Front Range in the Thompson Canyon, Poudre Canyon, and Virginia Dale areas: Field Guide; Geol. Soc. Am., pp. 106-120.

Cavosie A and Selverstone J 2003 Early Proterozoic oceanic crust in the northern Colorado front Range: Implication for crustal growth and initiation of basement faults; Tectonics 22 10-23.

Chamberlain K R 1998 Medicine bow orogeny: Timing of deformation and model of crustal structure produced during continent-arc collision $\sim 178 \mathrm{Ga}$, southeastern Wyoming; Rocky Mountain Geol. 33 259-277.

Cherniak D J, Watson E B, Grove M and Harrison T M 2004 $\mathrm{Pb}$ diffusion in monazite: A combined RBS/SIMS study; Geochim. Cosmochim. Acta 68 829-840.

Cihan M 2004 The drawbacks of sectioning rocks relative to fabric orientations in the matrix: A case study from the Robertson River Metamorphics (Northern Queensland, Australia); J. Struct. Geol. 26 2157-2174.

Cihan M and Parsons A 2005 The use of porphyroblasts to resolve the history of macro-scale structures: An example from the Robertson River Metamorphics, North- Eastern Australia; J. Struct. Geol. 27 1027-1045.

Cihan M, Evins P, Lisowiec N and Blake K 2006 Time constraints on deformation and metamorphism from EPMA dating of monazite in the Proterozoic Robertson River Metamorphics, NE Australia; Precambr. Res. 145 $1-2$.
Condie K C and Martel C 1983 Early Proterozoic metasediments from north-central Colorado: Metamorphism, provenance, and tectonic setting; Geol. Soc. Am. Bull. 94 $1215-1224$.

Dahl P S, Terry M P, Jercinovic M J, Williams M L, Hamilton M A, Foland K A, Clement S M and Friberg L M 2005 Electron probe (Ultrachron) microchronometry of metamorphic monazite: Unraveling the timing of polyphase thermotectonism in the easternmost Wyoming Craton (Black Hills, South Dakota); Am. Mineral. 90 1712-1728.

Gaidies F, Krenn E, de Capitani C and Abart R 2008 Coupling forward modelling of garnet growth with monazite geochronology: An application to the Rappold Complex (Austroalpine crystalline basement); J. Metamorph. Geol. 26 775-793.

Ham A P and Bell T H 2004 Recycling of foliations during folding; J. Struct. Geol. 26 1898-2009.

Hayward N 1990 Determination of early fold axis orientations within multiply deformed rocks using porphyroblasts; Tectonophys. 179 353-369.

Karlstrom K E, Dallmeyer R D and Grambling J A $1997{ }^{40} \mathrm{Ar} /{ }^{39} \mathrm{Ar}$ evidence for $14 \mathrm{Ga}$ regional metamorphism in New Mexico: Implications for thermal evolution of lithosphere in the southwestern US; J. Geol. 105 205-223.

Kelly N M, Clarke G L and Harley S L 2006 Monazite behaviour and age significance in poly-metamorphic highgrade terrains: A case study from the western Musgrave Block, central Australia; Lithos 88 100-134.

Kim H and Bell T H 2005 Combining compositional zoning and foliation intersection axes (FIAs) in garnet to quantitatively determine early P-T-t paths in multiply deformed and metamorphosed schists: North central Massachusetts, USA; Contrib. Mineral. Petrol. 149 141-163.

Ludwig K R 1998 Isoplot/Ex: A geochronological toolkit for Microsoft Excel; Berkeley Geochronological Center, Spec. Publ. 143.

Mancktelow N S 1981 Strain variation between quartz grains of different crystallographic orientation in a naturally deformed metasiltstone; Tectonophys. 78 73-84.

Montel J M, Foret S, Veschambre M, Nicolette C and Provost A 1996 Electron microprobe dating of monazite; Chem. Geol. 131 37-53.

Nyman M, Karlstrom K E, Graubard C and Kirby E 1994 Mesozoic contractional orogeny in western North America: Evidence from ca 14 Ga plutons; Geology 22 901-904.

Paquette J L, Nédélec A, Moine B and Rakotondrazafy M $1984 \mathrm{U}-\mathrm{Pb}$, single zircon Pb-evaporation, and Sm-Nd isotopic study of a granulite domain in SE Madagascar; J. Geol. 102 523-538.

Parrish R R $1990 \mathrm{U}-\mathrm{Pb}$ dating of monazite and its application to geological problems; Canadian J. Earth Sci. 27 1431-1450.

Pyle J M, Spear F S, Rudnick R I and McDonough W F 2002 Monazite-xenotime-garnet equilibrium in metapelites and a new monazite garnet thermometer; J. Petrol. 42 2083-2107.

Pyle J M, Spear F S, Wark D A, Daniel C G and Storm L C 2005 Contributions to precision and accuracy of chemical ages of monazite; Am. Mineral. 90 547-577.

Reed J C, Bickford M E Jr, Premo W R, Aleinikoff J N and Pallister J 1987 Evolution of the Early Proterozoic Colorado Province: Constraints from U-Pb geochronology; Geology 15 861-865.

Sanislav IV 2010 A long lived metamorphic history in the contact aureole of the Mooselookmeguntic pluton revealed by in situ dating of monazite grains preserved 
as inclusions in staurolite porphyroblasts; J. Metamorph. Geol. 29 251-273.

Sanislav I V and Shah A A 2010 The problem, significance and implications for metamorphism of 60 million years of multiple phases of staurolite growth; J. Geol. Soc. India 6 384-398.

Sanislav IV and Bell T H 2011 The inter-relationships between long-lived metamorphism, pluton emplacement and changes in the direction of bulk shortening during orogenesis; J. Metamorph. Geol. 29(5) 513-536.

Sayab M 2005 Microstructural evidence for N-S shortening in the Mount Isa Inlier (NW Queensland, Australia): The preservation of early W-E-trending foliations in porphyroblasts revealed by independent $3 \mathrm{D}$ measurement techniques; J. Struct. Geol. 27 1445-1468.

Sayab M 2006 Decompression through clockwise P-T path: Implications for an early $\mathrm{N}-\mathrm{S}$ shortening orogenesis in the Mesoproterozoic Mt Isa Inlier (NE Australia); J. Metamorph. Geol. 24 89-105.

Selverstone J, Hodgins M, Shaw C, Aleinikoff J N and Fanning C M 1997 Proterozoic tectonics of the northern Colorado Front Range; In: Geologic history of the Colorado Front Range Denver (eds) Bolyard D W and Sonnenberg S A, Rocky Mountain Association of Geologist, pp. 9-18.

Selverstone J, Aleinikoff J, Hodgins $\mathrm{M}$ and Fanning C M 2000 Mesoproterozoic reactivation of a Paleoproterozoic transcurrent boundary in the Colorado Front Range: Implications for ca 17 and $14 \mathrm{Ga}$ tectonism; Rocky Mountain Geol. 35 136-162.

Shah A A 2009 FIAs (Foliation Intersection/Inflection Axes) preserved in porphyroblasts, the DNA of deformation: A solution to the puzzle of deformation and metamorphism in the Colorado, Rocky Mountains USA; Acta Geol. Sin. 83 801-840.
Shah A A 2010 Tectono-metamorphic evolution of Big Thompson Canyon Region Colorado Rocky Mountains, USA; Unpublished PhD thesis, James Cook University, B-22.

Shaw C A, Karlstrom K E, Williams M L, Jercinovic M J and McCoy A M 2001 Electron microprobe monazite dating of ca 171-163 Ga and ca 145-138 deformation in the Homestake shear zone, Colorado: Origin and early evolution of a persistent intracontinental tectonic zone; Geology 29 739-742.

Sims Paul K, Stein and Holly J 2003 Tectonic evolution of the Proterozoic Colorado province, Southern Rocky Mountains: A summary and appraisal; Rocky Mountain Geol. 38(2) 183-204.

Spiess R and Bell T H 1996 Microstructural controls on sites of metamorphic reaction: A case study of the interrelationship between deformation and metamorphism; European J. Mineral. 8 165-186.

Tweto O L 1987 Rock units of the Precambrian basement in Colorado US; Geological Survey Professional Papers 1321-A 54.

Williams M L 1994 Sigmoidal inclusion trails, punctuated fabric development, and interactions between metamorphism and deformation; J. Metamorph. Geol. 12 1-21

Williams M L and Jercinovic M J 2002 Microprobe monazite geochronology: Putting absolute time into microstructural analysis; J. Struct. Geol. 24 1013-1028.

Williams M L, Jercinovic M J and Terry M P 1999 Age mapping and dating of monazite on the electron microprobe: Deconvoluting multistage tectonic histories; Geology 27 1023-1026.

Williams M L, Jercinovic M J, Callum J and Hetherrington 2007 Microprobe monazite geochronology: Understanding geologic processes by integrating composition and chronology; Ann. Rev. Earth Planet. Sci. 35 137-175. 